$$
\begin{aligned}
& \text { تثيكوسلو فاكيا انمودج للفصل السلمي و التحول من نظام شيوعي } \\
& \text { اتشتر اكي الى نظام راسمالي ليبر الي الإخفاق و النجاح }
\end{aligned}
$$

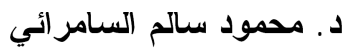

$$
\begin{aligned}
& \text { استاذ الدراسات الدولية المساعد/ كلية العلوم السياسية/ جامعة الموصل لفيل } \\
& \text { مستخلص البحث }
\end{aligned}
$$

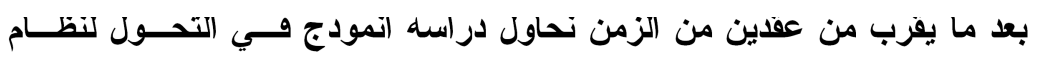

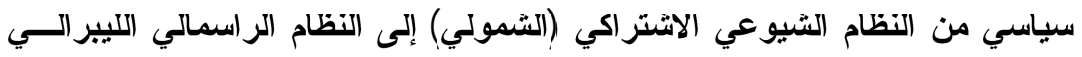

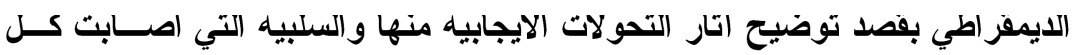

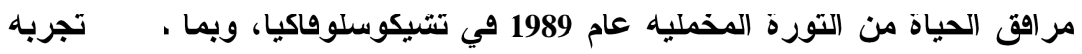

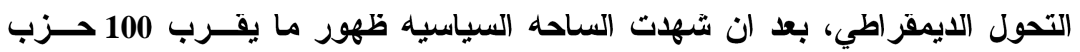

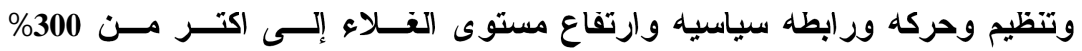

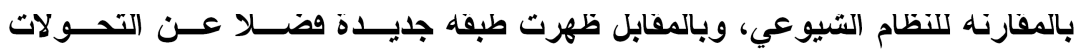

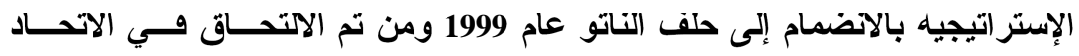

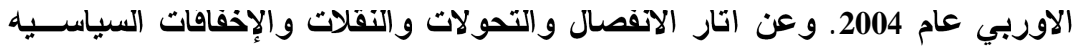
و الاوتصاديه والامنيه مند عام 1993 - 2009.

المقدمه

بعد ما يقرب من عقدين من الزمن نحاول دراسة انموذج في التحـــول

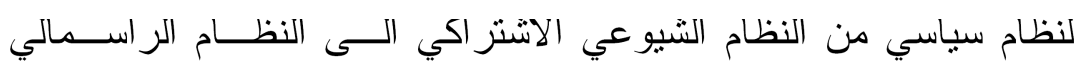

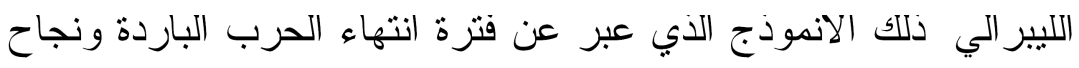

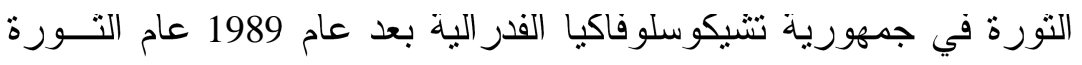

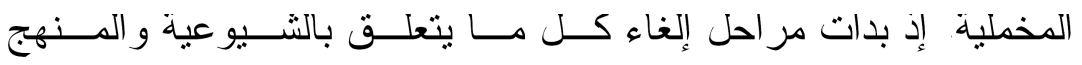

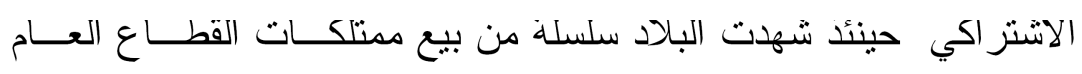

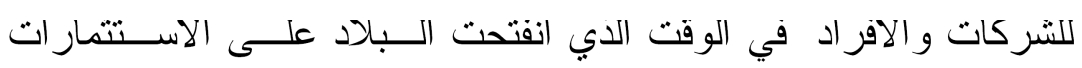


الاجنبية و الخارجية، و اندفعت الثركات الاجنبية بشكل و اسع وبخاصــة الغربية منها.

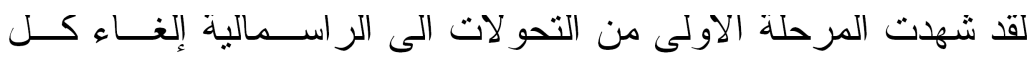

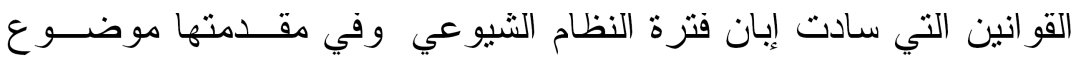

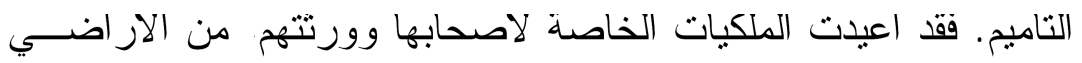
و المز ارع الكبيرة، و المصانع و غيرهات

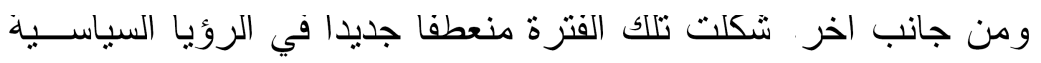

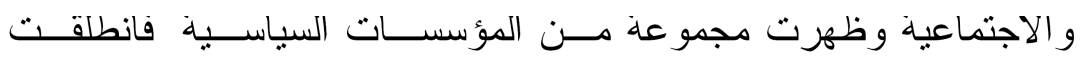

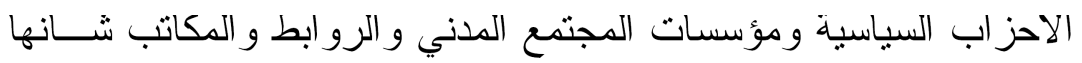
شان ما هو موجود في الدول الغربية الليبر الية. كما عشنا فنرة نجاح الثورة المخملية عام 1989 في تشيكوســلـوفاكيا، وبما هقته تجربة التحول الديمقر اطي من نجاح، بعد ان شهدت الســاحة

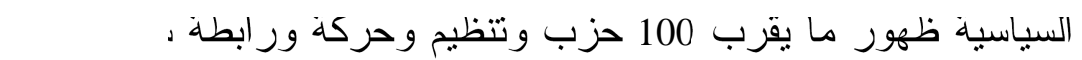

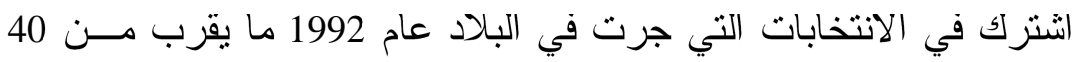
حزبا سياسيا، في وقت تعددت الصحف بشكل كبير و اتسع نطاق وســائل الاعلام، وهو امر طبيعي في مثل هذا التحول من نظام شمولي إلى نظام تعددي ديمقر اطي وفي حقيقة الامر كنا شـاهد|(1) على انواع من القبول و الــرفض فــي

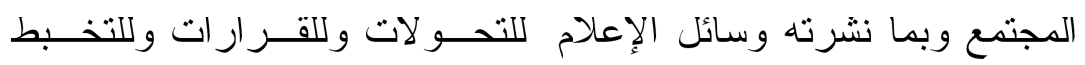

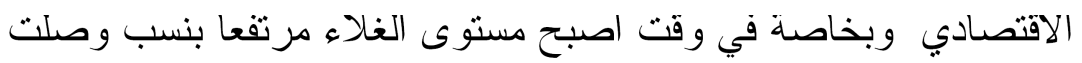

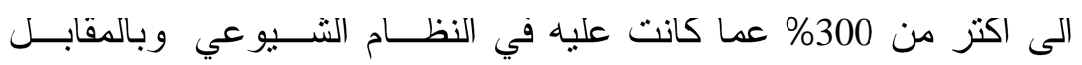

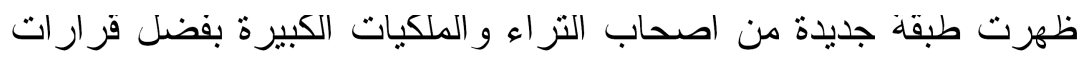

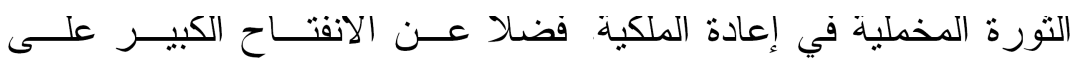
الاستتمار ات الخارجية، كما شهدت البلاد موجة من فقدان الامن و انتشـار 
الجريمة و البطالة، و على الرغم من دلك و اصل القادة السياسيون توجهاتهم

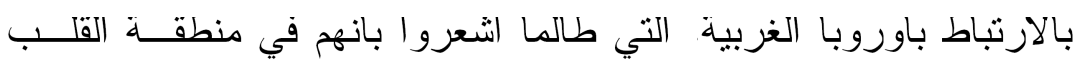

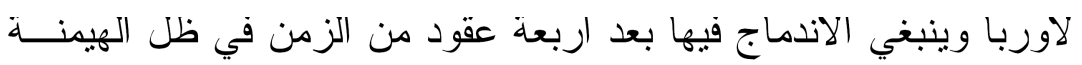

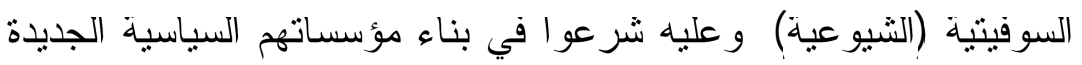
و الاقتصادية القائمة على تبني الديمقر اطية و اقتصاد السوق.

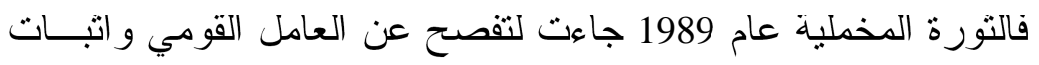

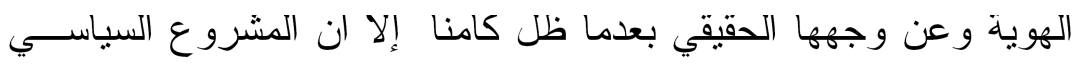

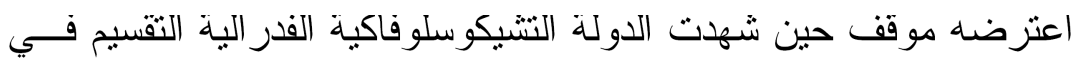

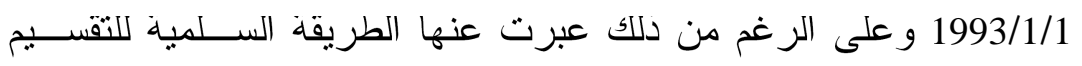

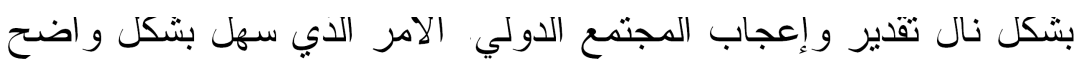
عملية الاعنر اف بالكيانين معا النتشيك و السلو فاك.

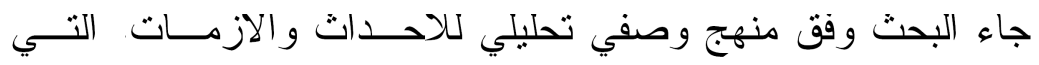

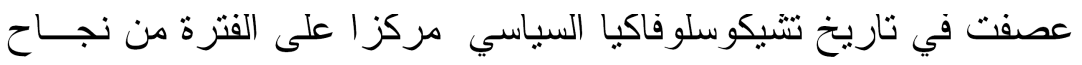

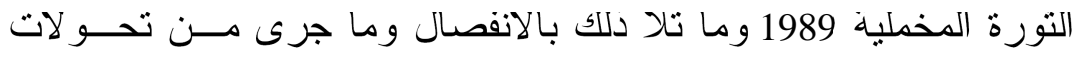

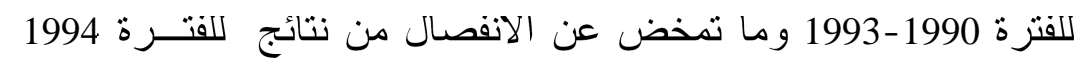

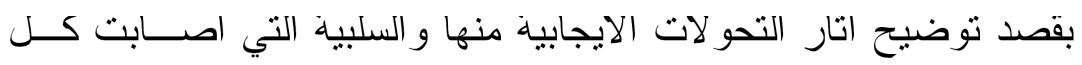

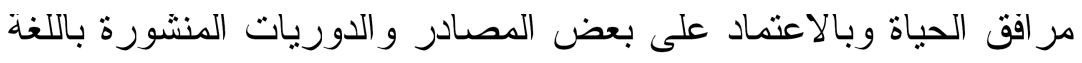

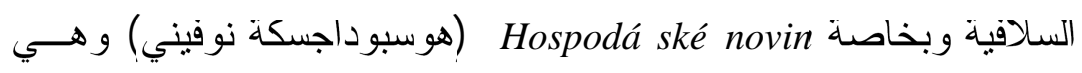
الصحيفة الاقتصادية الرسمية التي تصدر في العاصمة بر اغاغ.. التي بدلنا

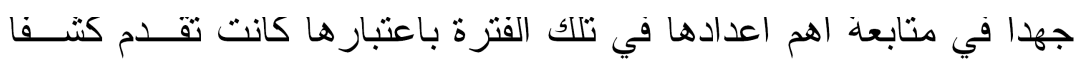

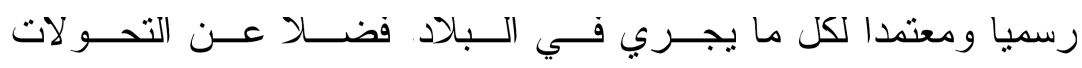

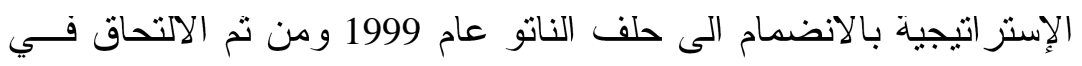

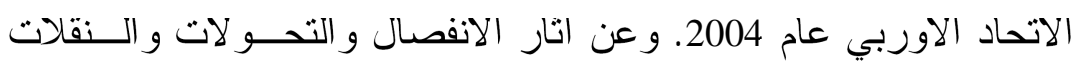
و الإخفاقات السياسية و الاقتصادية و الامنية منذ عام 1993 حتى عام 2009. 
كانت نشيكوسلوفاكيا جز عا من الإمبر اطورية النمساوية المجرية حتى

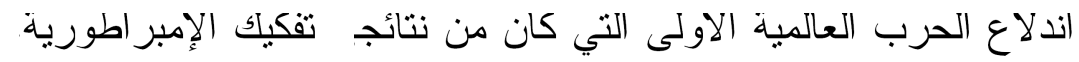

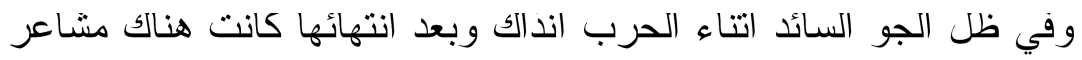
وطنية في كل من التشيك و السلوفاك تتجه نحو فكرة إنشاء دولـــة، و إز اء

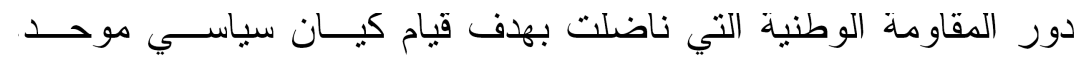

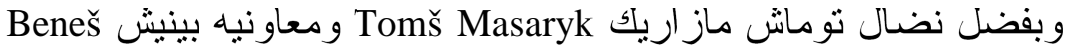
من اصل (تشيكي) وميلان ستيفانيك (سلوفاكي) اصبحت الفكرة تسير نحو التحقيق الفعلي بتاسيس المجلس الوطني التشيكوسلوفاكي الذي اقيم عـام

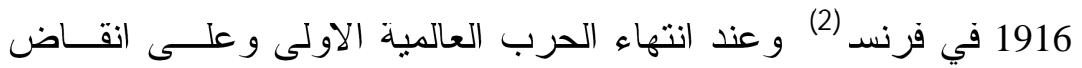

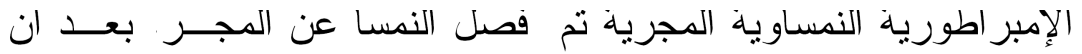
اقتطع الحلفاء مساحات كبيرة من حدود الإمبر اطورية القديمة لتوزع عله

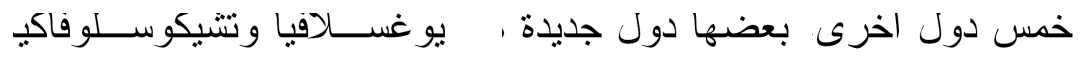

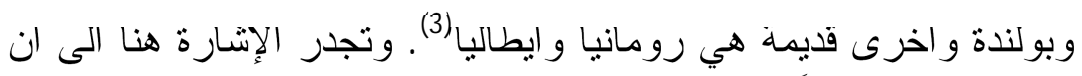

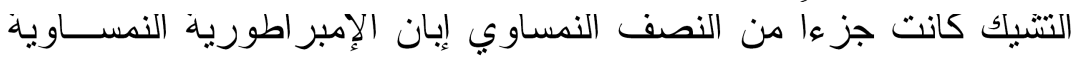
الهنغارية، وعند بروز الظاهرة القومية التي عصفت في دول اوربا كان

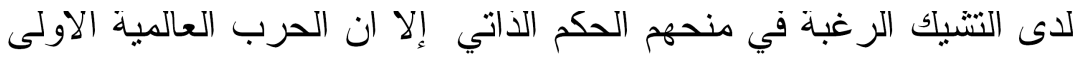

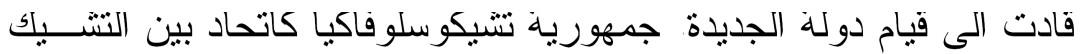

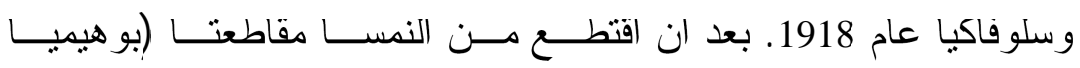

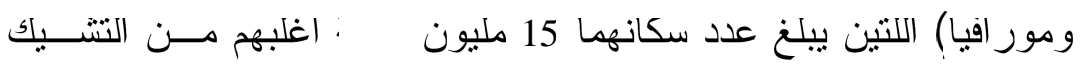
ومليونين من السلوفاك ومليون من المجريين و الرونتين ليتم دمجهم بدولنة جديدة). (4).

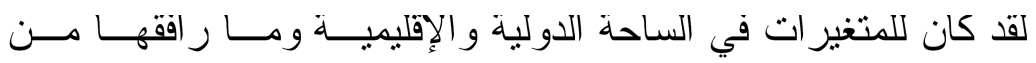

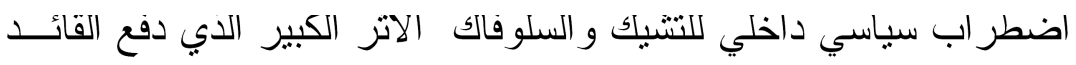


السياسي انداك (توماش ماز اريك) بإعلان الاستقلال لتنتيكوسلوفاكيا فـي

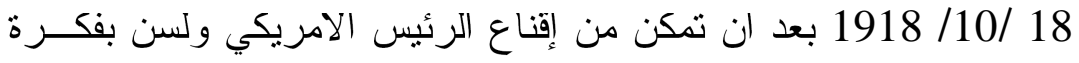

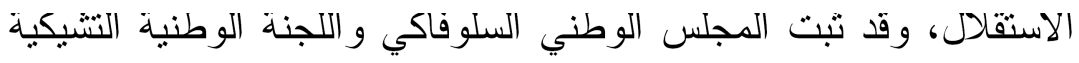

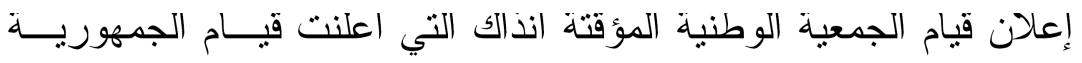

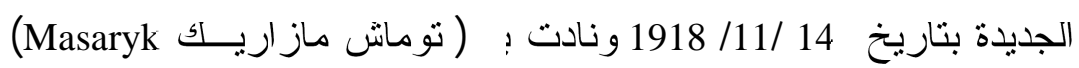
رئيسا لها. الذي تمكن من توحيد الدولة على الرغم من الخلافات و والتباين

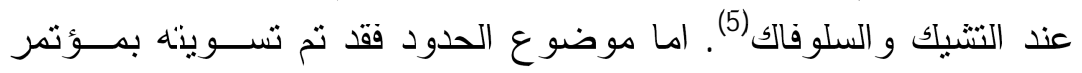

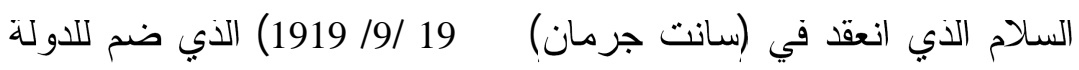

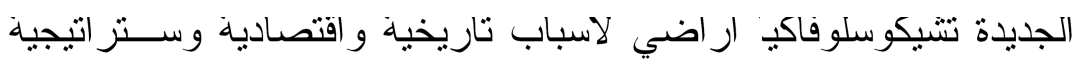

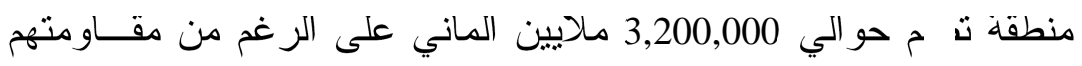

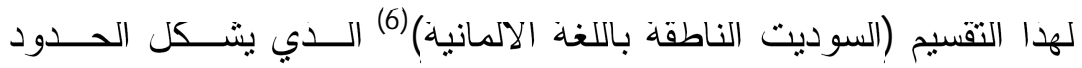

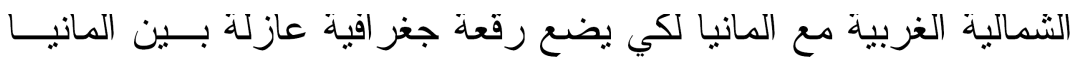

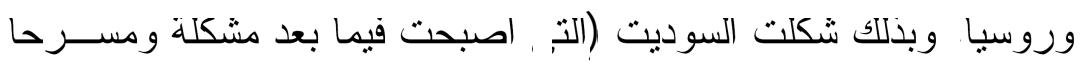

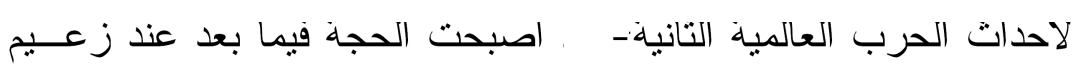

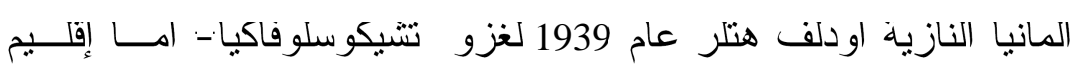
(تيسين) قسم بين تشيكو سلوفاكيا وبولونيا النيا.

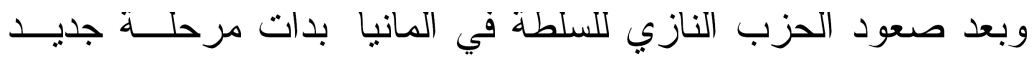

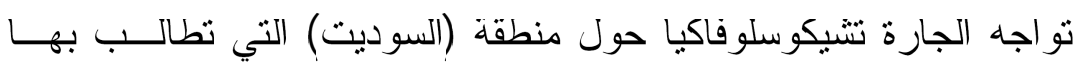

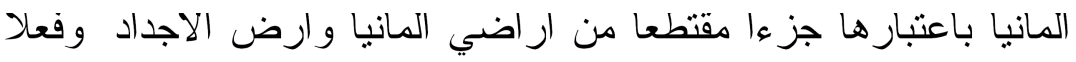

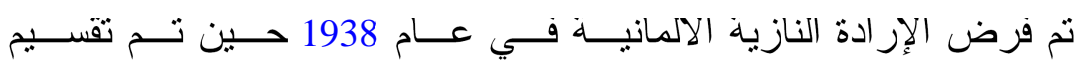

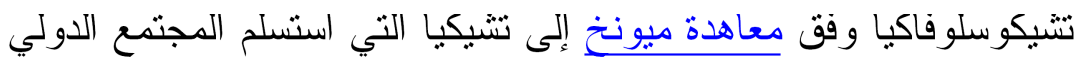

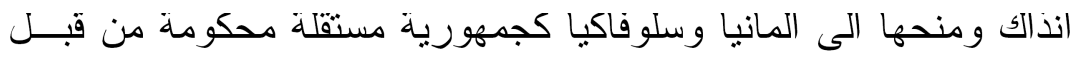

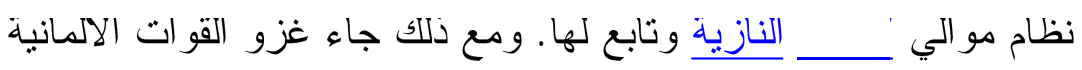
لبلقي تشيكوسلوفاكيا ووقع الثعب النشيكي في شهر اذار 1939 بعد تقسيم 
تشيكو سلوفاكيا تحت السيطرة الالمانية. و اعلن عن قيام حكومة وصاية لــــ (التشيك ومور افيا) قبل اندلاع الحرب العالمية الثنانية(8).

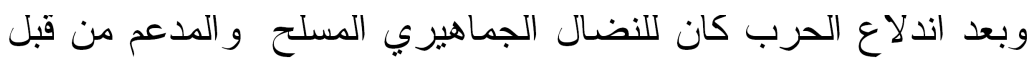

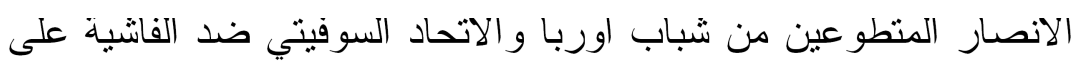

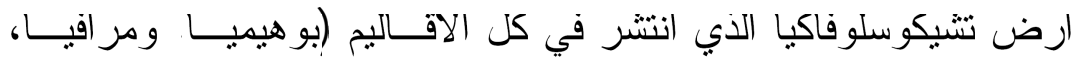

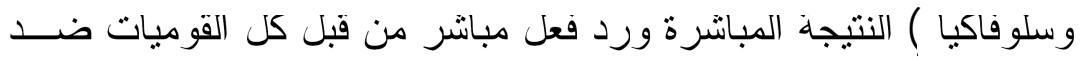

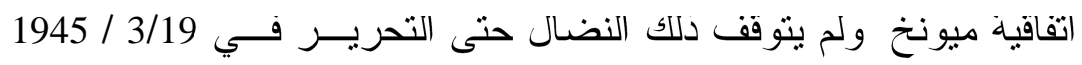
وبعد استسلام المانيا غير المشروط،اعيد نتكيل جمهورية تشيكوسلوفاكيا

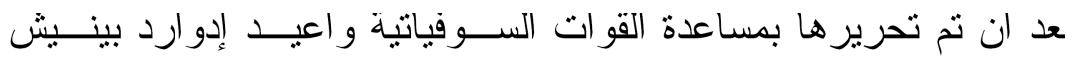
(Beneš) الإتحاد السوفيتي الحليف. ريتان. في 25 شباط عام 1948 بلغن التوتز السياسي ذروته في البلاد، الامــر

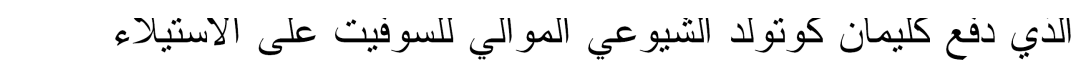

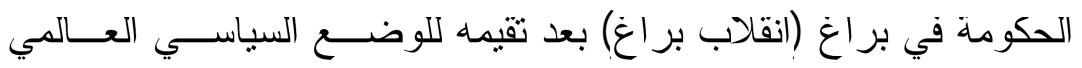

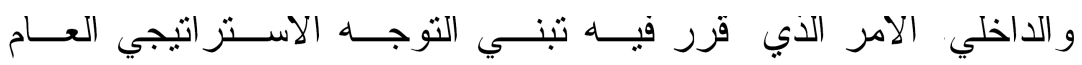

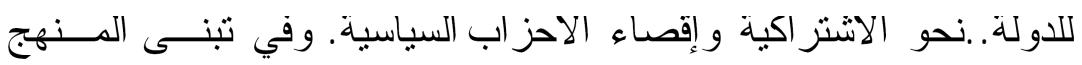

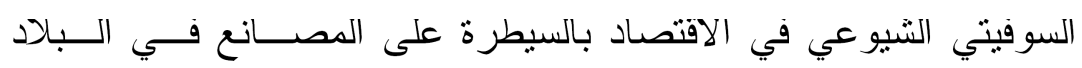

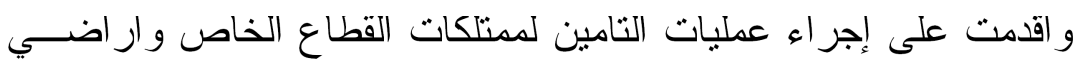
المز ارعين تللك التي ربطت بالقوة وبشكل جماعي من خلال (جمعيـات فلاحيه تعاونية). ومن جهة اخرى منعت الحكومة الثيوعية كل اتـــكال المعارضة السياسية في البلاد كما قلصت من نفوذ وتاثير الكنائس الدينية،

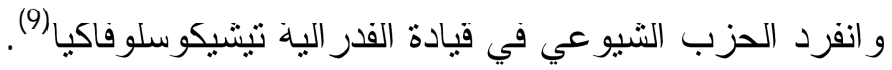




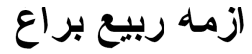

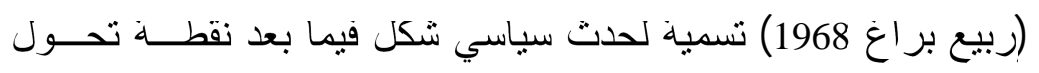

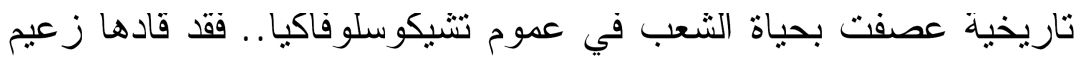

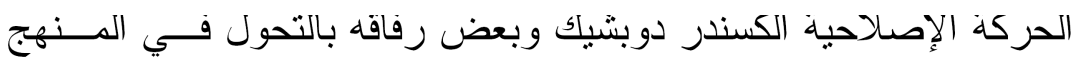

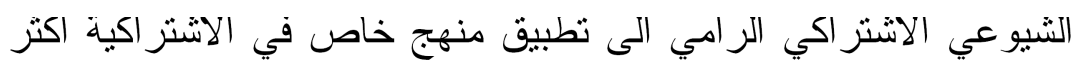

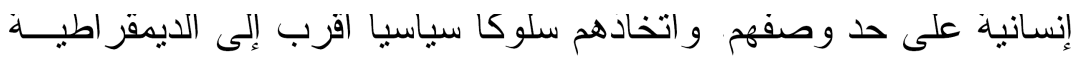

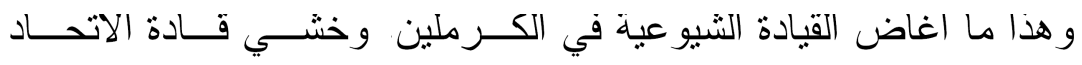

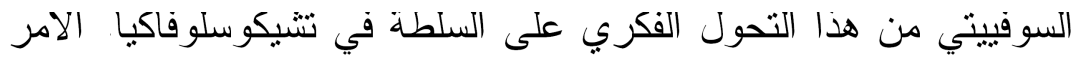

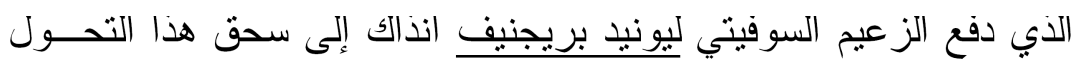

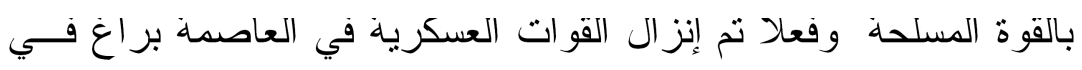

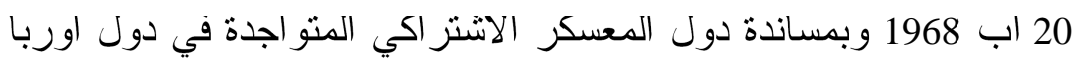

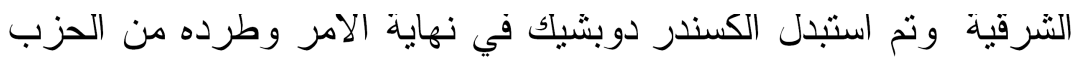

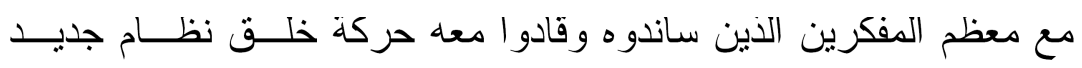

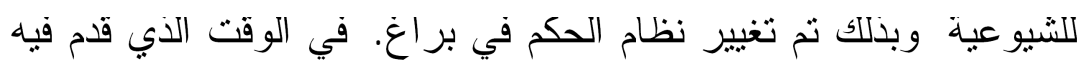

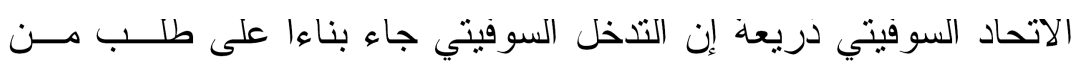

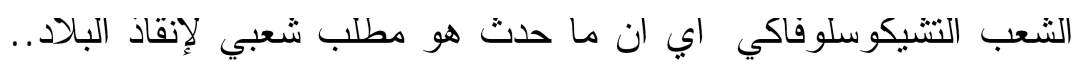

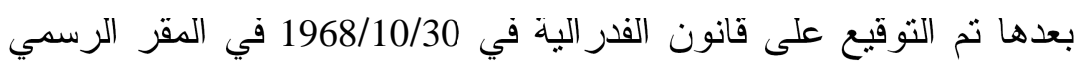

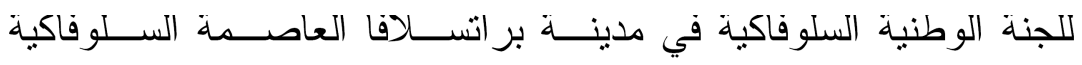
و اصبحت تثيكو سلوفاكيا دولة ذات نظام فدر الي (10).

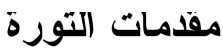

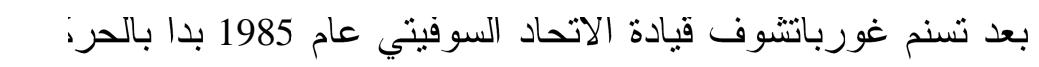

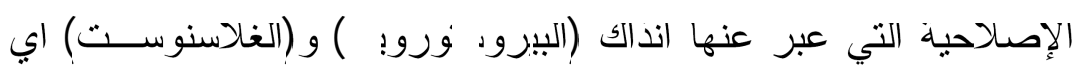

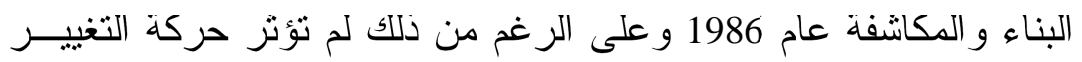


التي اندلعت بالاتحاد السوفيتي على طبيعة الحكم في تشيكوسلوفاكيا للفترة

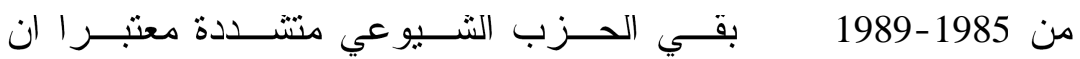

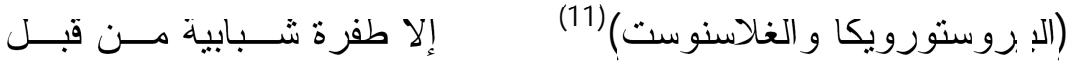
غورباتشوف وستزول عند تطبيقها على الو اقع، إلا ان الو اقع كثف حقيقة

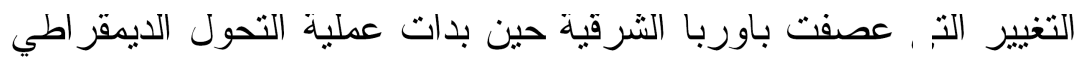

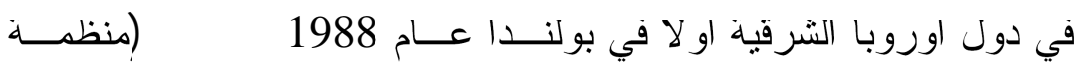

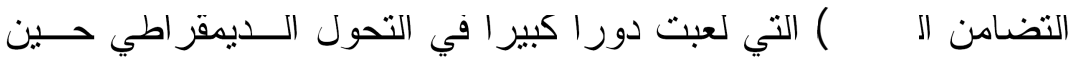

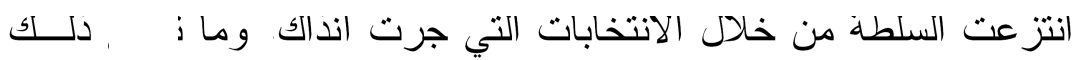

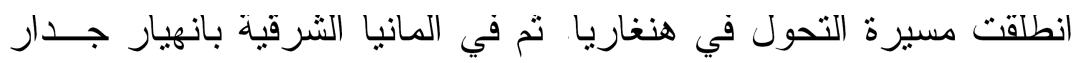
برلين، لتجد تشيكو سلوفاكيا طريقها حين تحولت النظاهرة الطلابية السلمية

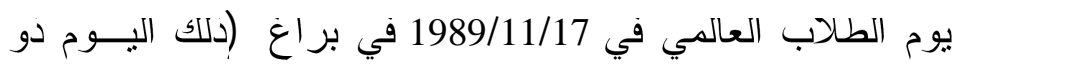
العلاقة الوثيقة بتاريخ الكفاح التشيكي ضدم الاحتلال النازي ففي هذا اليوم

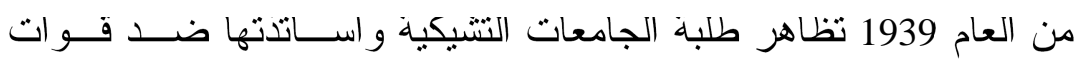
الاحتلال النازيغ فقتل و اعتقل اكتر من 3000 طالب واستاد...)(12) ويوم 17 تشرين التاني صادف الذكرى الخمسين لمناسبة (يوم الطالب فئب

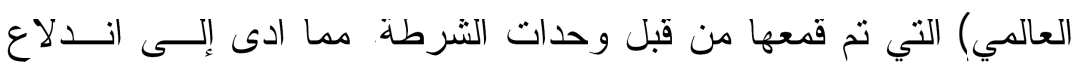

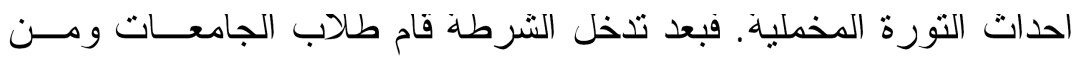

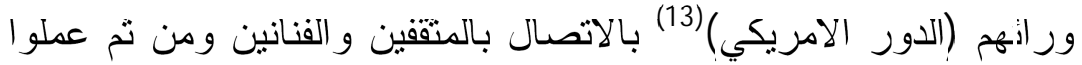

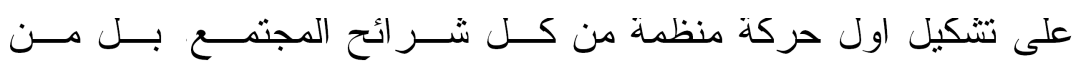
المعارضين لنظام الحكم الثيوعي، الني اطلق عليها مجموعة ميتاق 77 تم من مجمو عات وصلت الى 40 مكونسيلسي، الامر الذي ادى الى تشكيل

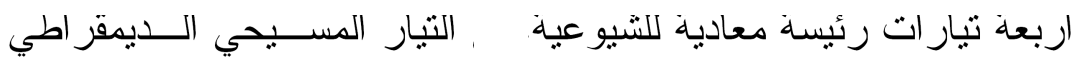

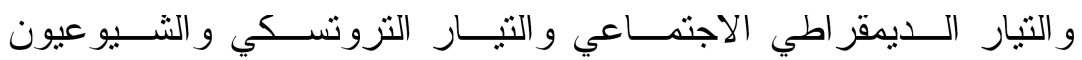

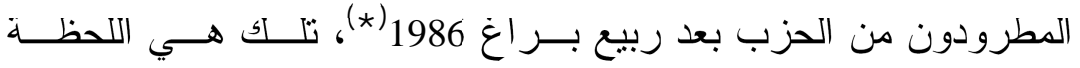




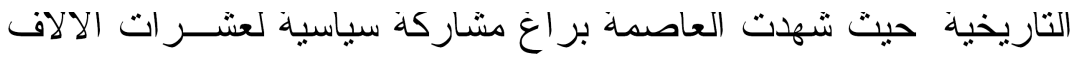

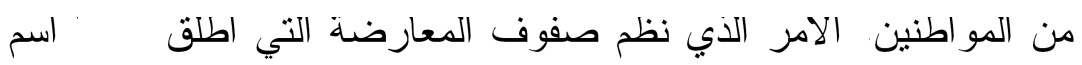

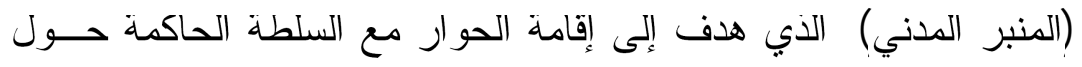

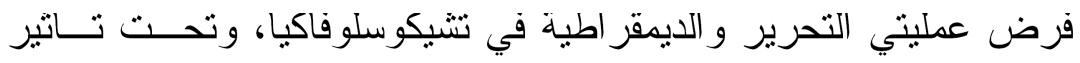
الضغط السياسي الذي بلغ ذروته في الإضر اب العام الذي تم الإعلان عنده

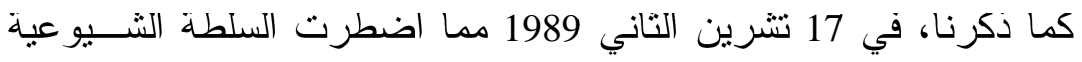

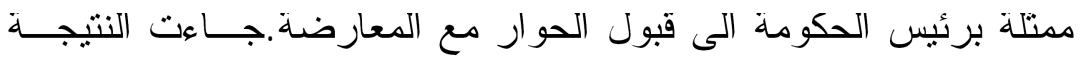

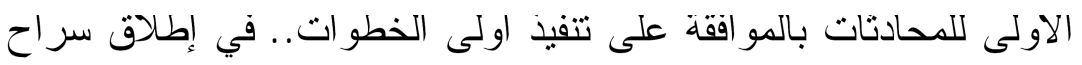

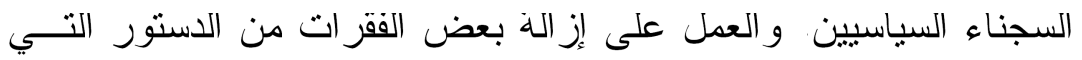

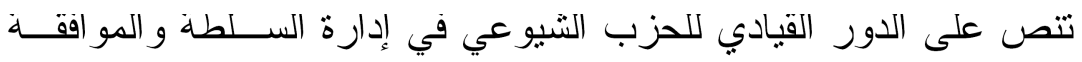

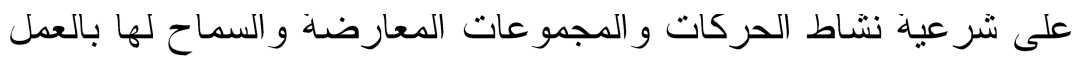

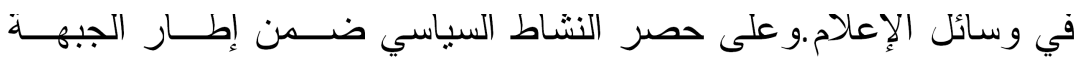

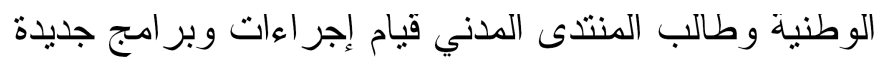

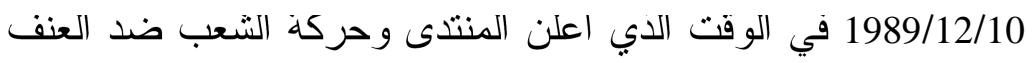

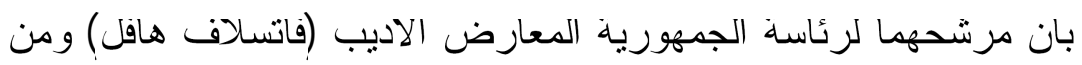

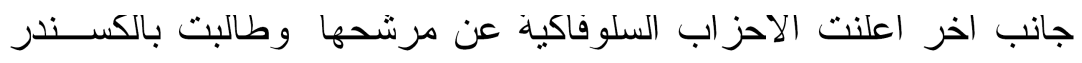

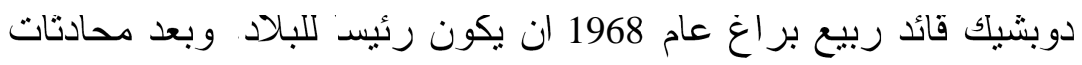

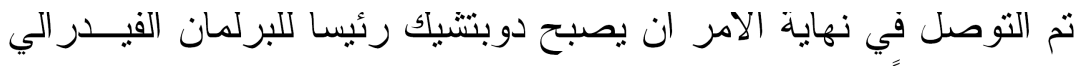
و هافل رئيساً لتنتيكو سلو فاكيا.

نجاح التورة المخمليه 1989

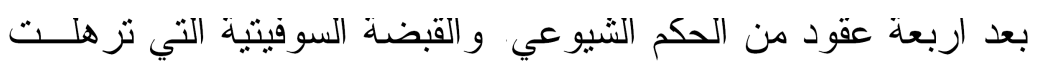

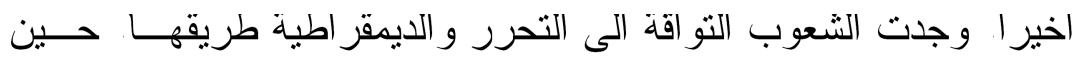

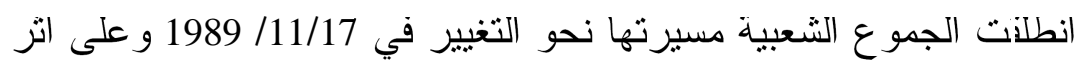


التظاهرة الطلابية التي حدثت في قلب العاصمة براغ 14، تلك التظـــاهرة

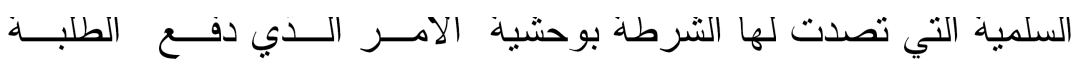

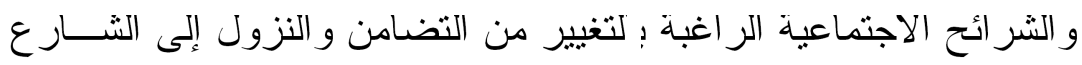

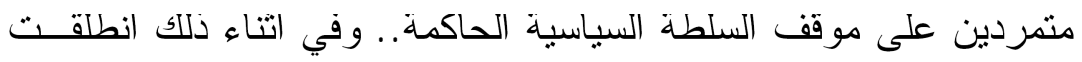
الفرف الموسيقية النشيكية تعزف للمحتجين وتزيد من حماستهم مما راحت

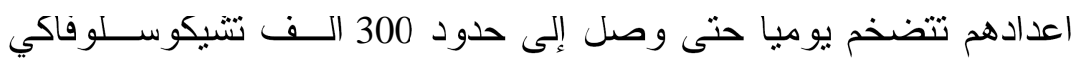

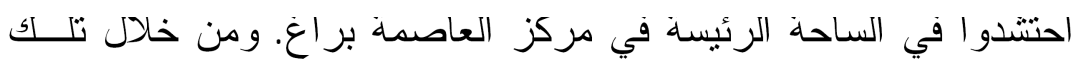

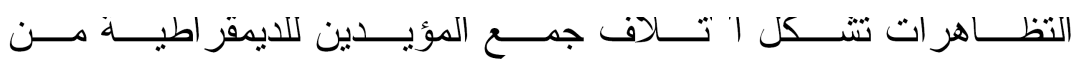

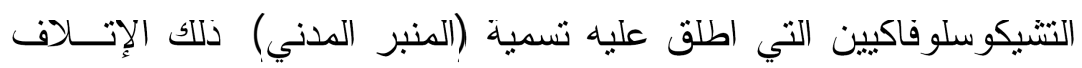

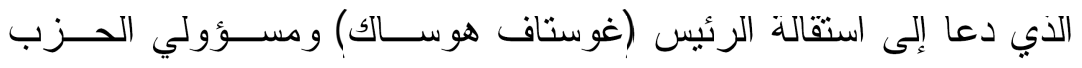
الشيوعي.. وما هي إلا ايام معدودة حتى تمت الاستجابة الى مطلــبـ الجمـــاهير

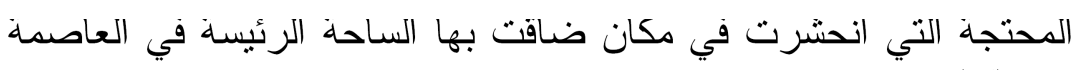
بر اغ(15). ومن على شرفة مبنى الحكومة اديع بيان استقالة الحكومة ملبية

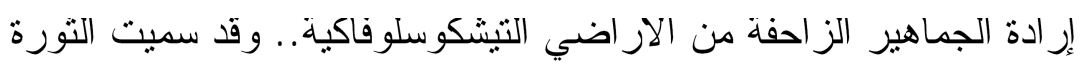

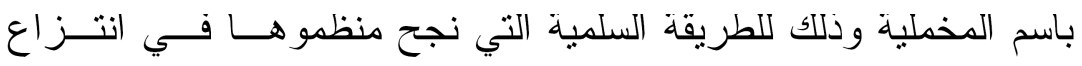

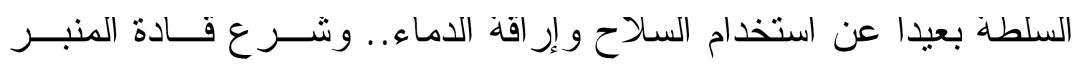

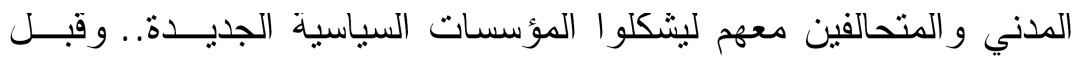

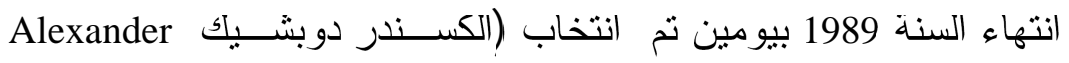
(Dubček زيم ربيع بر اغ عام 1968 رئيسا للجمعية الاتحادية،وتم اختيار

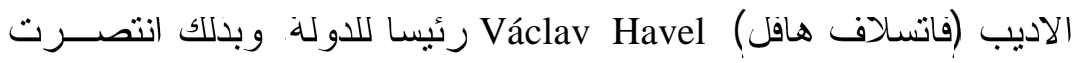
الثورة المخملية وانحسرت الثيوعية. وشرعت البلاد نحو نظام جديد يقوم

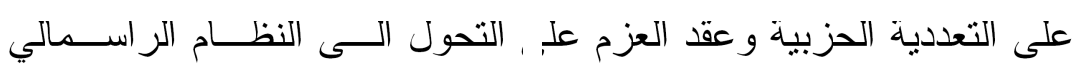
الليبر الي. 


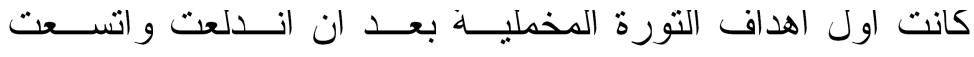

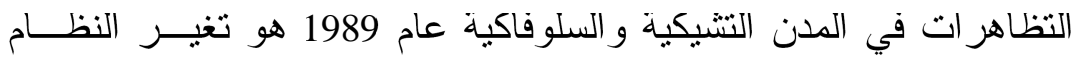

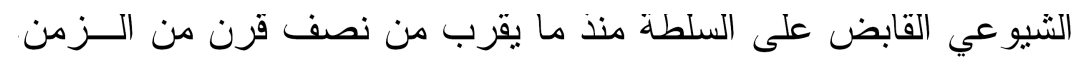

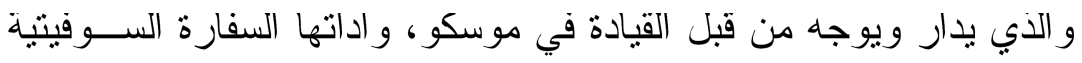

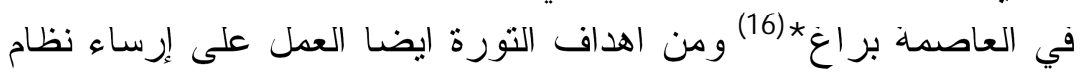

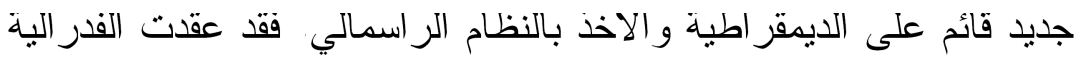

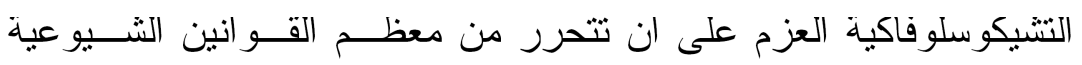

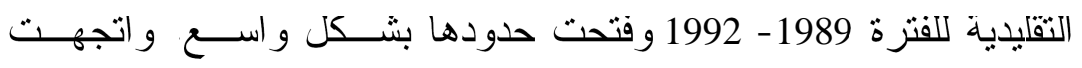

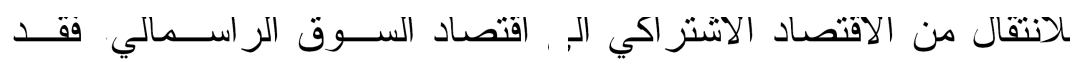

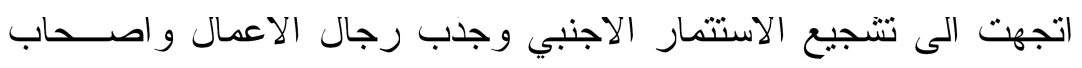

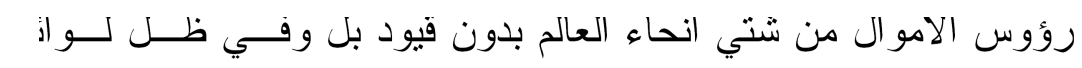

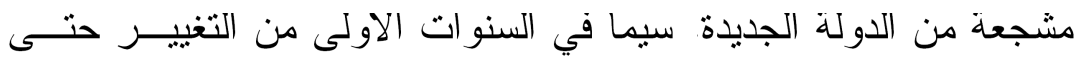
اصبح كل شيء يمكن شر اؤه.

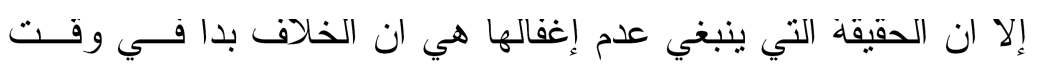

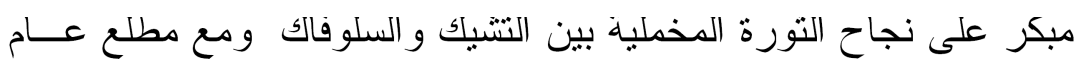

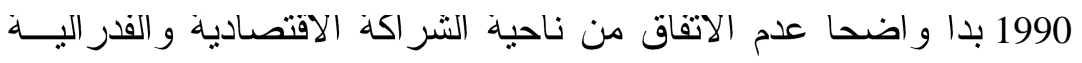

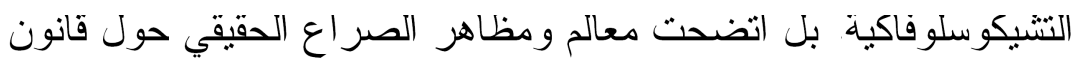

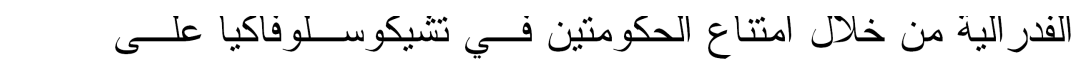

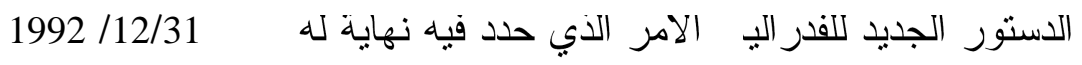

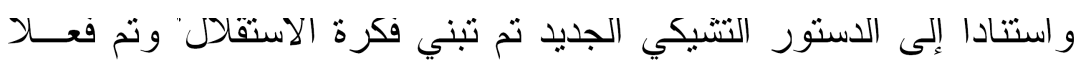

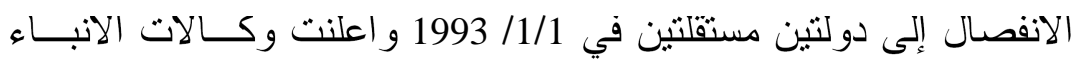
الدولية حدث الانفصال (17).

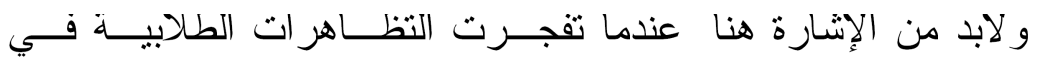
1989/11/17 في بر اغ لتصل الى بر اتيسلافا عاصمة سلوفاكيا في غضون 


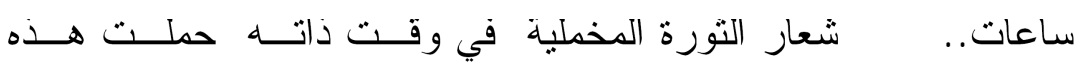

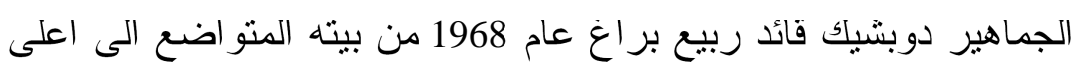

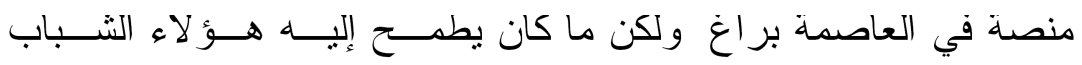
المتظاهرون هو اكبر بكتير من شعار دوبتشيك (اشتر اكية بوجه إنساني)

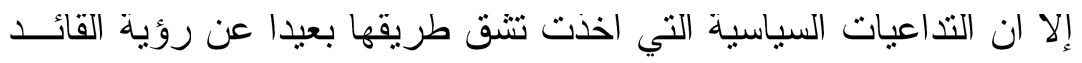

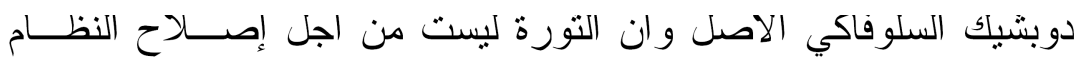

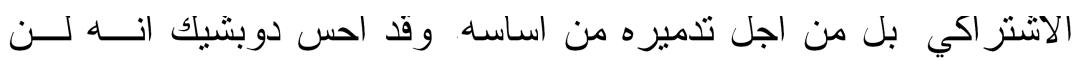

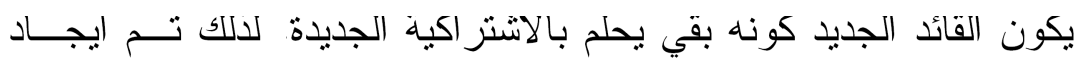

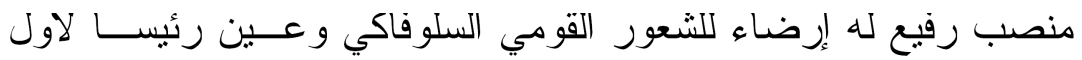

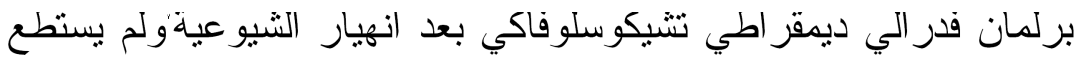

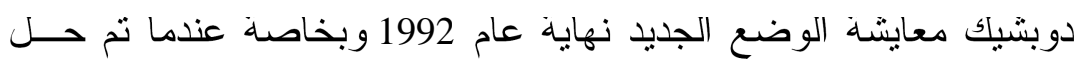
البرلمان الفدر الي واتخاذ الإجراءات لإندان لانقسام الدولة الموحدة.

\section{سمات التورة}

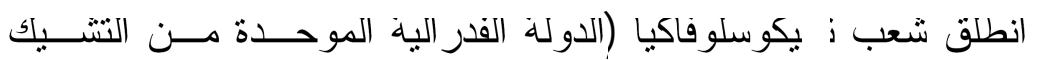

و السلوفاك) انذاك في مسيرة سياسية اصبحت تعرف في العالم "بــالتورة

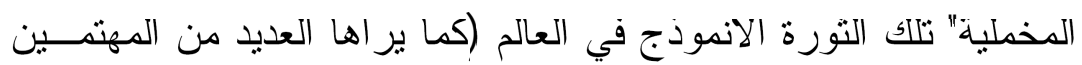

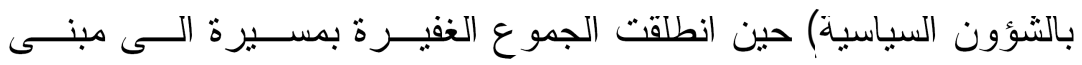
الحكومة مطالبة بسقوط الحكومة ونظامها السياسي... ومسـن دون إر اقــة

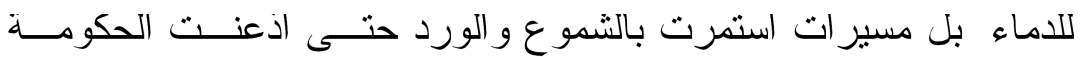
وقدمت استقالتها امام المطلب الجماهيري الواسع الذي عصـــ بـ بالحيــاة السياسية انداك، و على الرغم من النورة قدمت شهذاءها الدين سقطو ا اتر

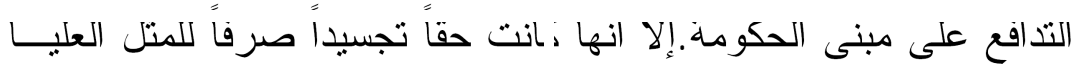

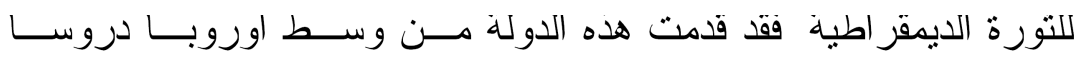
للحركات و القوى السياسية في اوربا ودول العالم... بــان مــنـهج التــورة 


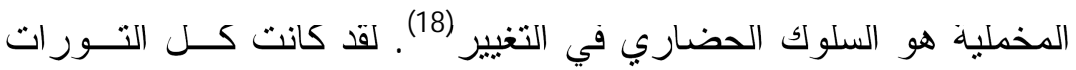

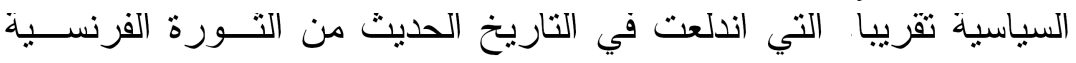

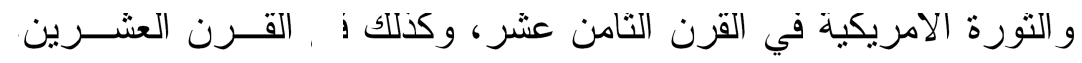

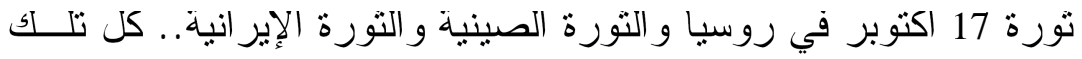

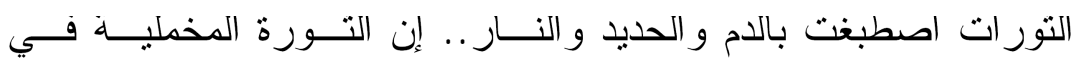

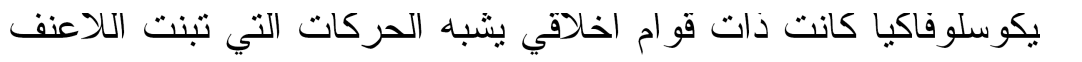

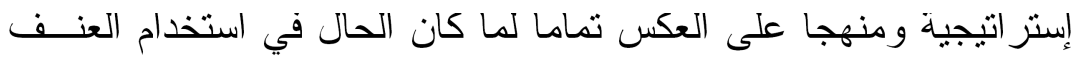

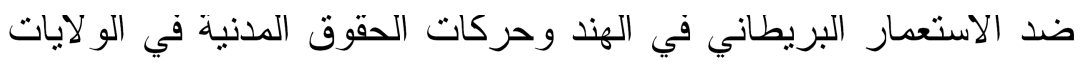
المتحدة الامريكية (19). وتعد التورة المخملية حقيقة، التورة التي لم تكن ادو اتها العنف و الحديد

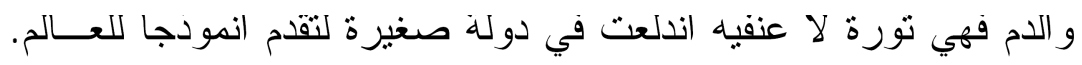

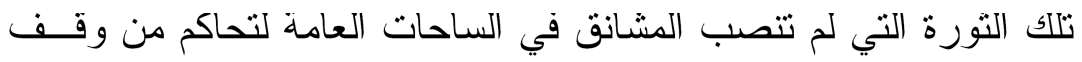

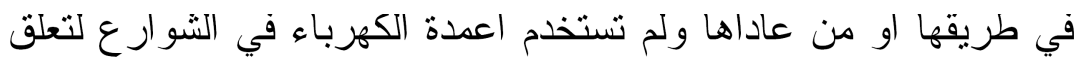

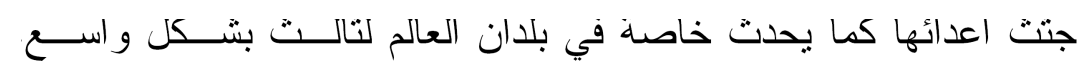

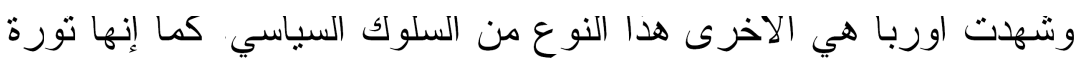

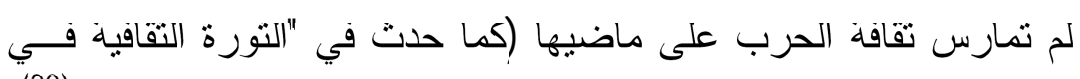

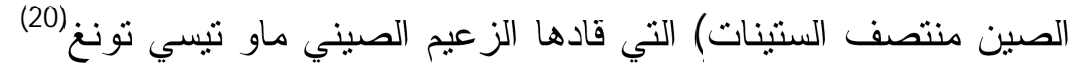

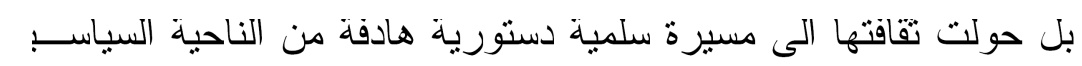

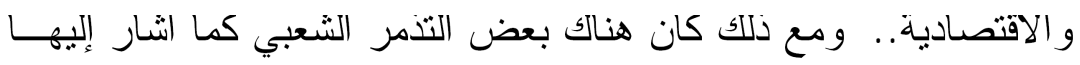
بiné změny

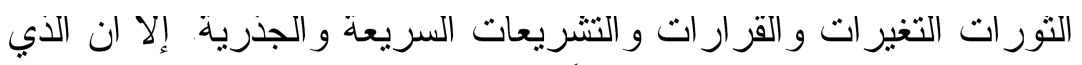

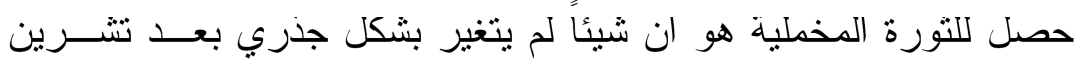

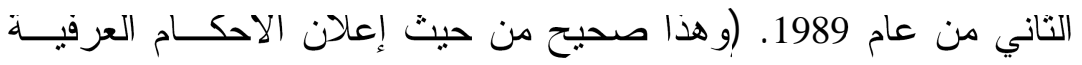
وتعليق الدستور إلا ان مسيرة النورة جاءت بنقلات نوعية بعد ان امسكت العت التهن 


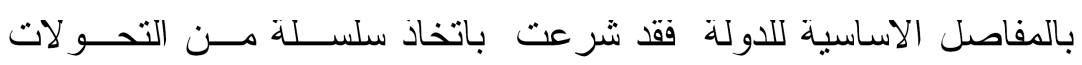

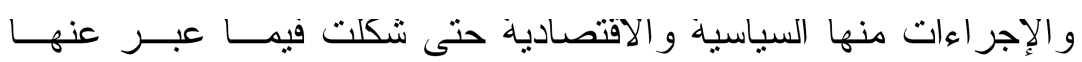

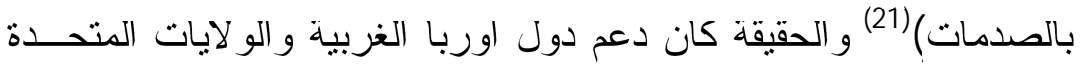

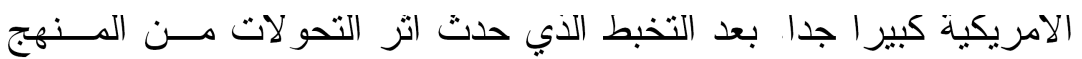
الاشتر اكي الى اقتصاد السوق.

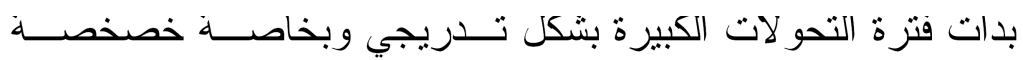

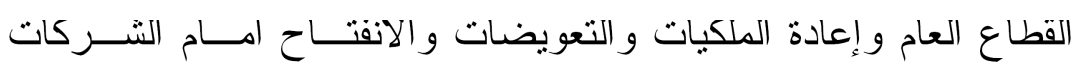
الاجنبية، اي تبني الليبر الية القائمة على اقتصاد السوق كمنهج اقتصادي،

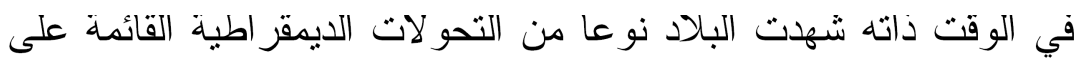
التعددية الحزبية، وفق ما جاء به الدستور الجديد للاولة الجديدة كمــنهج

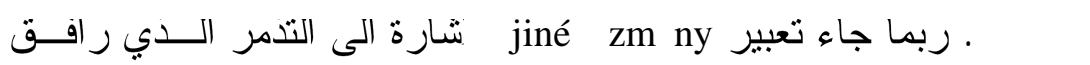
عملية التحول من انعدام الامن وارتفاع الجريمة والارتفاع الهائل للاسعار

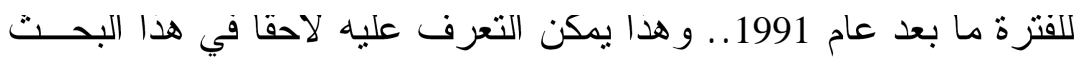

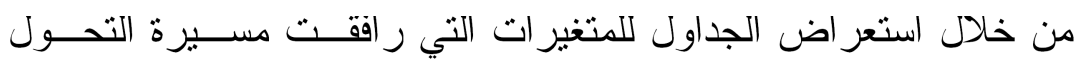
السياسي والاقتصادي و الامني في البلاد. إن الثورة التشيكوسلوفاكية التي

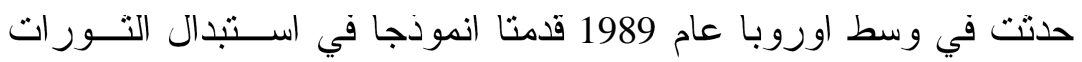

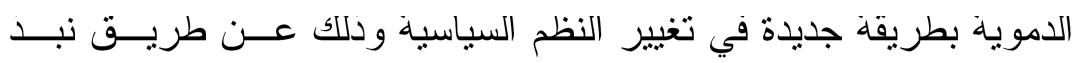

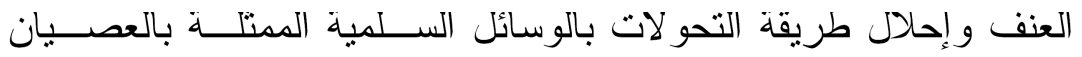
المدني، و التظاهر ات الحاشدة و المستمرة، فقد حملت ثورة عام 1989 ف مي لتولي

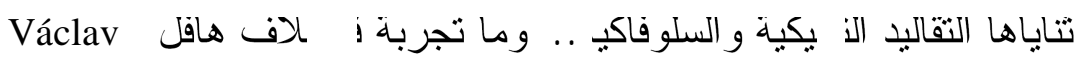
(اول رئيس لجمهورية نشيكوسلوفاكيا بعد نجاح الثورة المخملية)

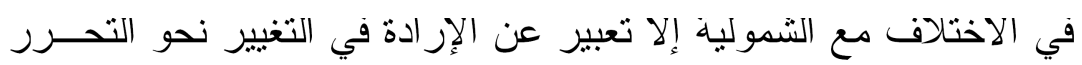

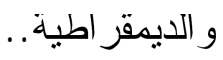




\section{الدعم الغربي للتورة المخمليه}

ينظر الى تتشيكوسلوفاكيا على انها من اكتر الاقتصـــادات الصــــاعية

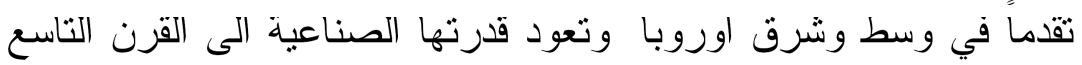

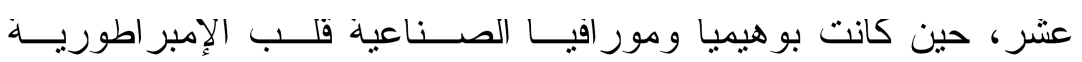
النمساوية - الهنغارية. وقد ادى هذا الامر الى إرساء بنيان للقاعدة التحتية

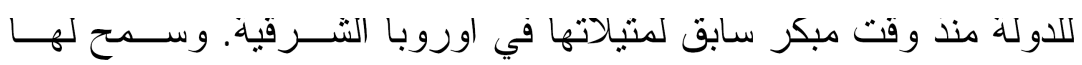

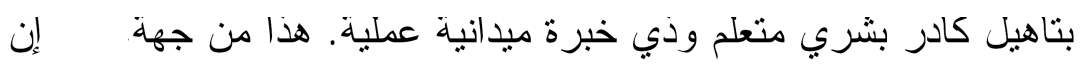

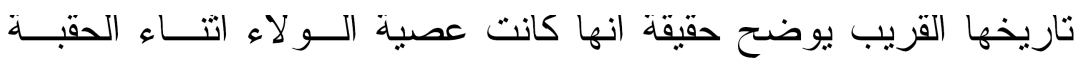

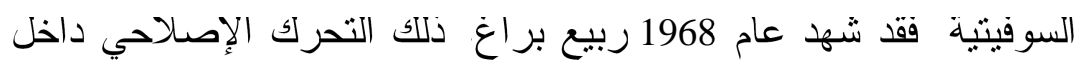

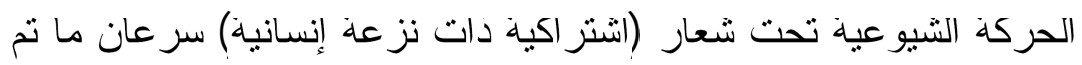

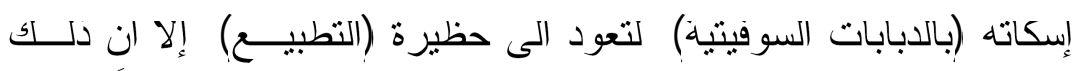

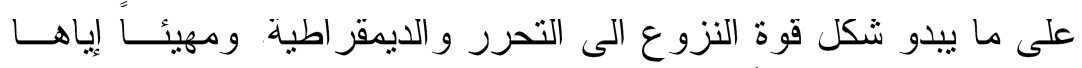

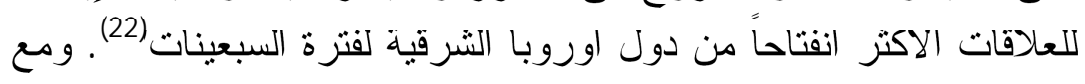

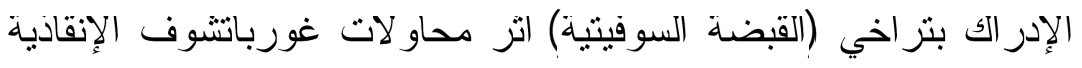
تحت عنو ان \البيرويسترويكا و الغلاسنوسته هبت تانية بانتفاضة مخملية

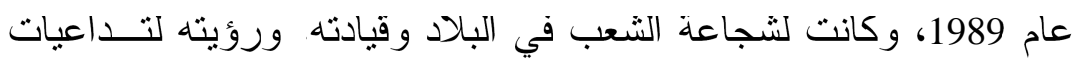

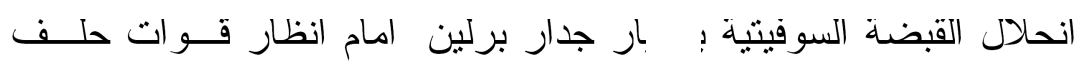

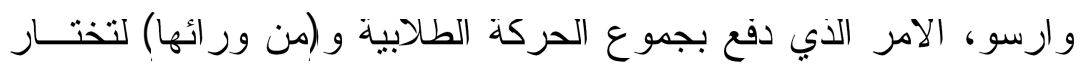

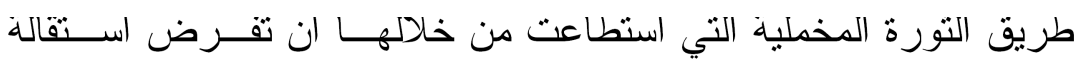

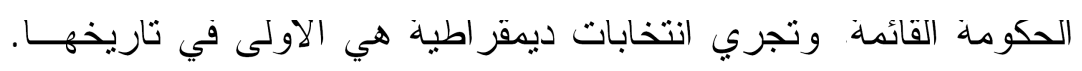

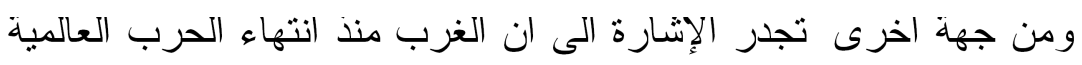

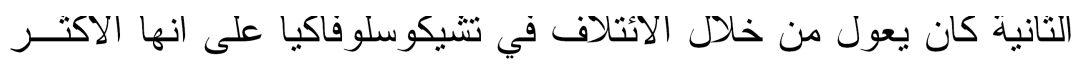

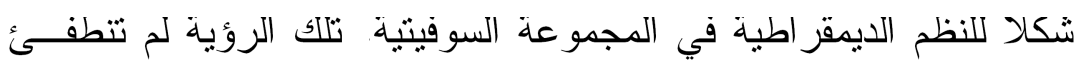

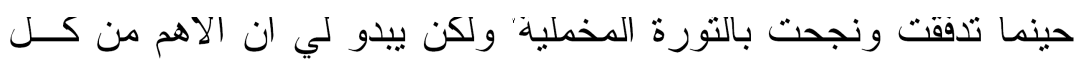


ذلك، هو الدعم الذي قدم من قبل الولايات المتحدة الامريكية ودول اوروبا

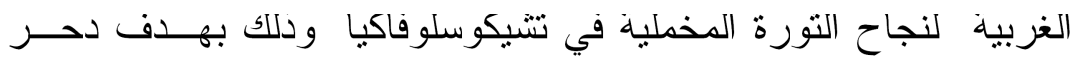

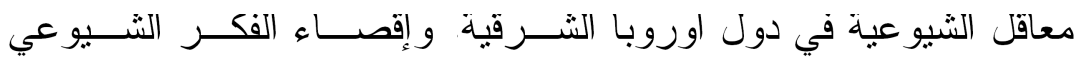

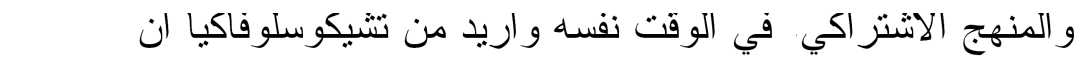
انموذجا ينبغي الاحتذاء به من قبل دول اوروبا الثُرقية فضئل فن عن إنهاء كل ما يتعلق بالنظام الثنيو عي من ذاكرة المجتمع و اعتباره إرثا في ذاكئ ذاكرة الشعوب الاوربية الشرقية(23) وعليه اندفعت الشركات دات الغربية والامريكية و القت بتقلها لصمود الدولة الجديدة دات التوجه الديمقر اطي و الر اسمالي، ولاكيه

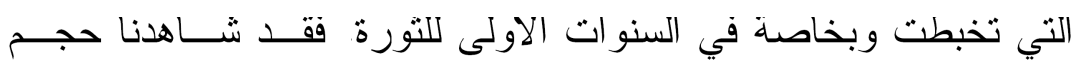
الشركات المتدقة لمعظم الدول الغربية التي عالجت الوضع الاقتصـــادي، لادي،

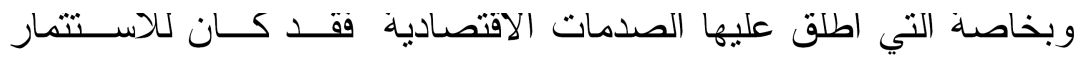
الغربي الريادة في وقوف منهج الثورة المخملية من الإخفاق، كما لاحظنا

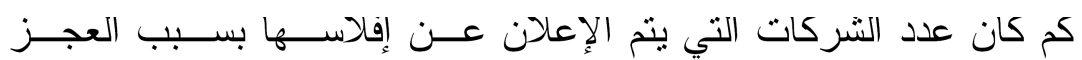

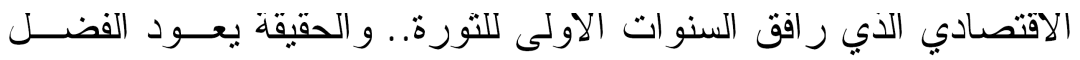

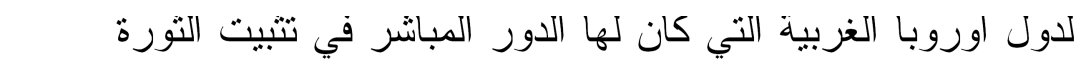

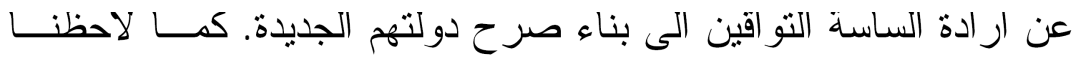
حجم التدقق للشباب الامريكي في البلاد منهم من جاء لتعلم اللغة السلافية

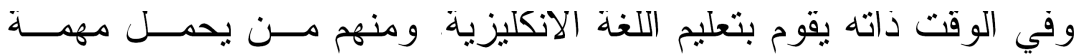

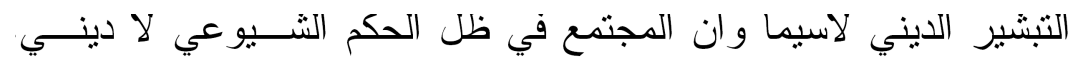

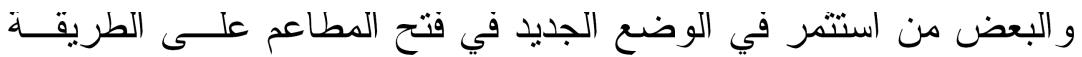
الامريكية مثل مكدونلد، و المجمعات النسويقية الاوربية. و انتشرت التنقافة

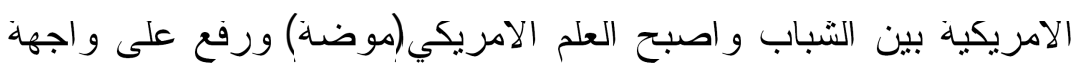

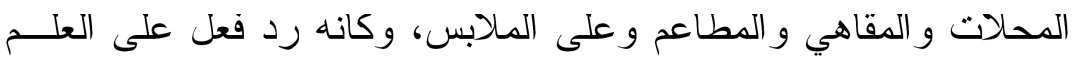
السوفيتي الذي كان يرفع في المناسبات. 


\section{التحولات الاقتصاديه والاجتماعيه والامنيه}

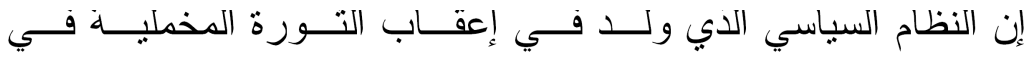

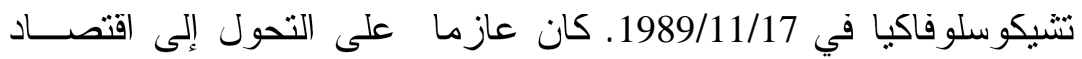

السوق، اي الاخذ بالر اسمالية على النمط الغربي، فقد عمل على تذمير كل

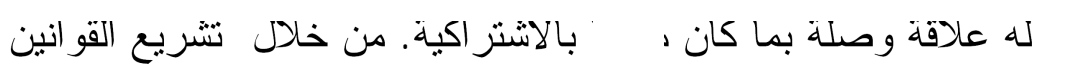

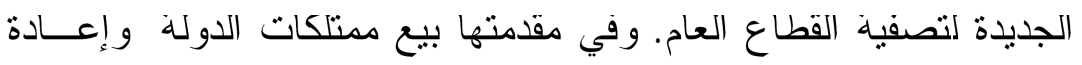

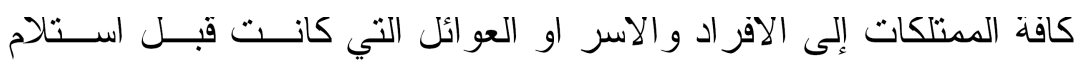
الحزب الثنيو عي النتثيكوسلوفاكي السلطة عام 1948، تلك التي كانت من التن الطبقات الغنية و البرجو ازية والتي تم الاستيلاء على ممتلكاتها ومصادرتها

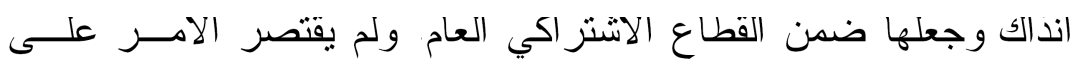

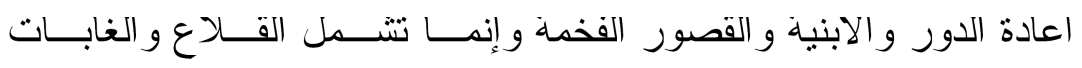

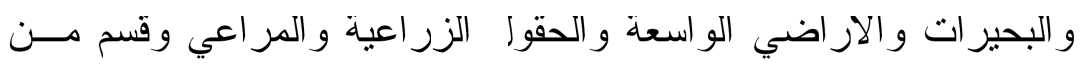

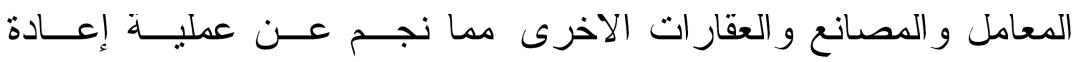

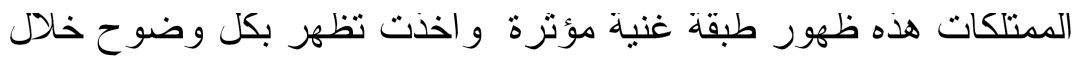

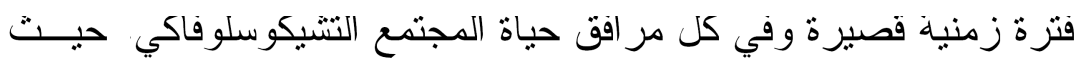
تعدت ارصدة البعض من افر اد هذه الطبقة المالية المليار ات و القسم الاخر

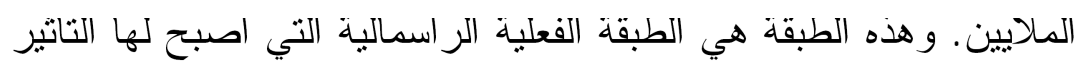
المباشر على النخبة الحاكمة حسب القو انين للنظام الر اسمالي.

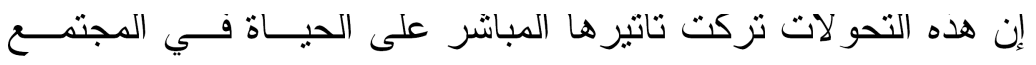
فازداد الفقير فقرا و الغني غنى، كما برزت ظو الهر غير مالوفة سابقا في

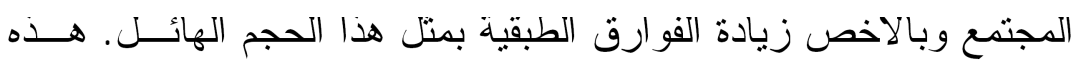

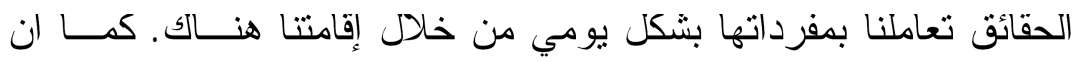

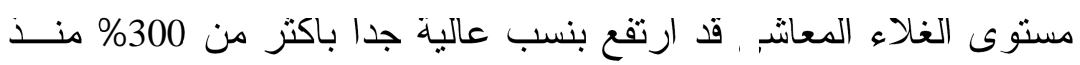

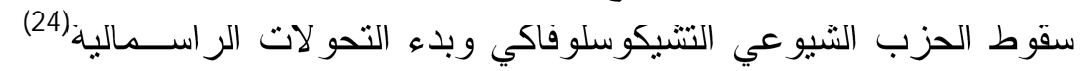


كل تلك الإجر اءات نركت تاثير ا وعبئا مباشر ا على كاهل المو اطن وبات يعاني بشدة نتيجة ارتقاع الاسعار لكل المواد الاساسية من مواد اد غذائيــة

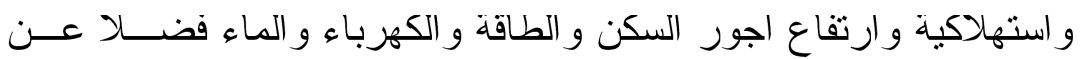
ظهور البطالة و التضخم المالي.

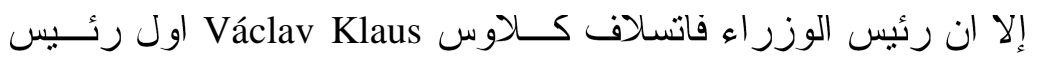

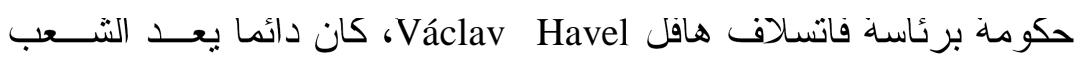
بحياة مزدهرة، ويصر ح بمثل هذا التفاؤل مشير ا إلى ان كل بداية صعبة،

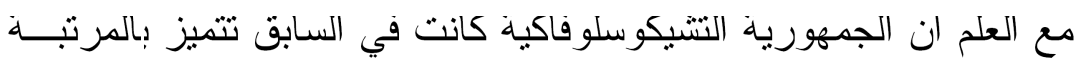
الاولى عن بقية بلدان اوربا الشرقية المنظمة إلى حلف وارسو من ناحية التطور الاقتصادي و الصناعي و الرفاهية الاجنماعية.

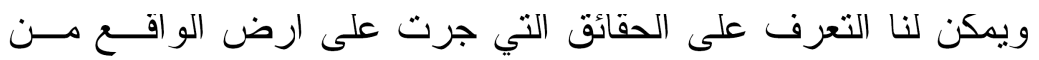

خلال ترجمة ما نشرته الجريــدة الاقتصــادية(Hospodářské noviny ) (هوسبوداجيسكة نوفيني)(25) التي كانت مرجعنا لمتابعة كل التحو لات التي

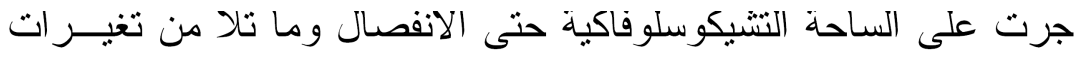
في الميادين الاقتصادية و الاجتماعية والامنية و افردنا بشكل خاص الجانب التبه

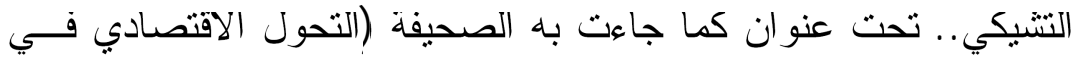
بدايته وهو على مطلع ابو اب عام جديدة في مرحلة صعبة).

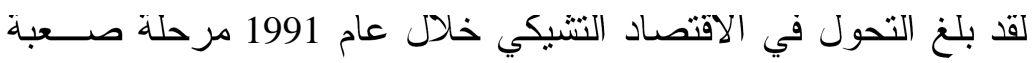

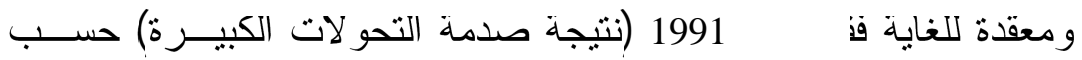
وصف الصحيفة الاقتصادية حصل انفجار هائل في مسـتوى الاســعار و ارتفعت خلال النصف الاول وحده من نلك السنة بنسبة 50\% اي (بنسبة التهبة \%0 اكثر مما كانت عليها في سنة 1989) و انخفض الإنتاج القومي خلاد وله شهر كانون الثاني إلى الربع مقارنة مع السنة نفسها. وخلال عــام 1992

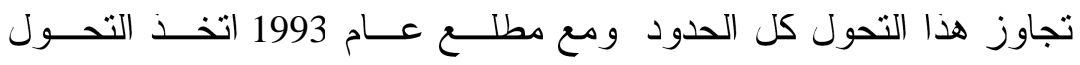




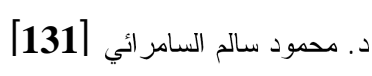

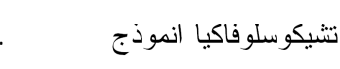

الاقتصادي طريقا جديدا دا اوجه مختلفة من عدم الوضوح متجاوز ا كـلـل

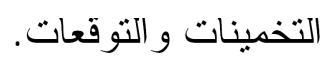

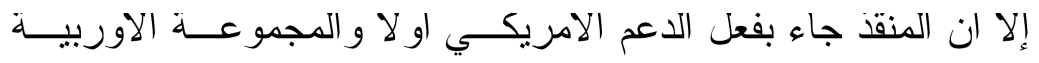

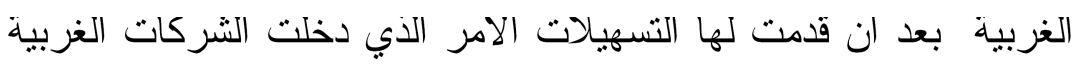

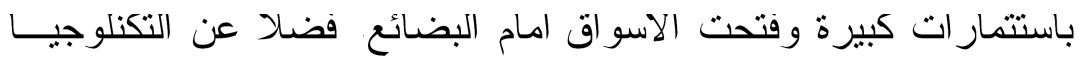

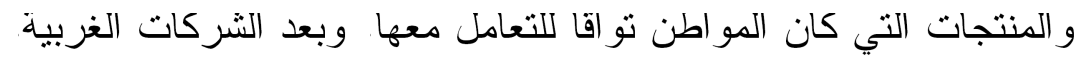

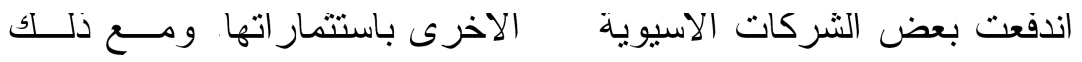

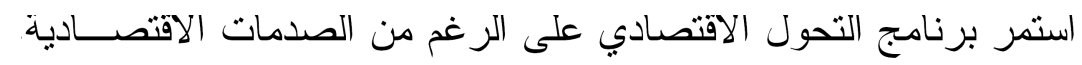

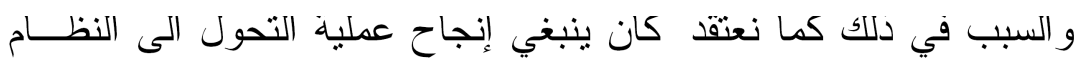

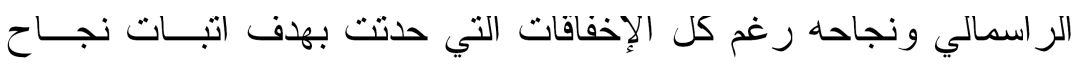
التجربة التنيكية واعتبار ها انمودجا للنحول لدول اوربا الثرقية و الاقتداء

الصدمات الاقتصاديه

لقد حصلت صدمتان اقتصاديتان طو ال فترة عمليات التحول(26)، كانت

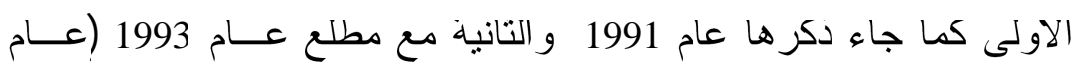

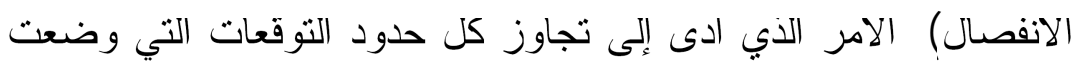

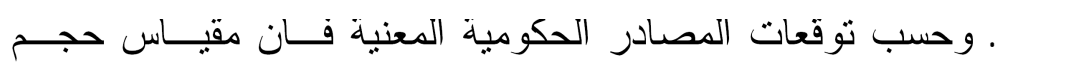

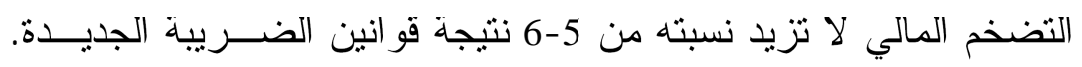

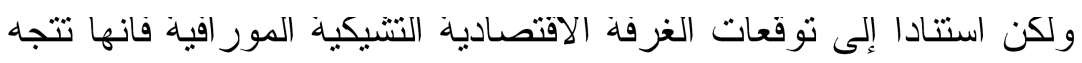

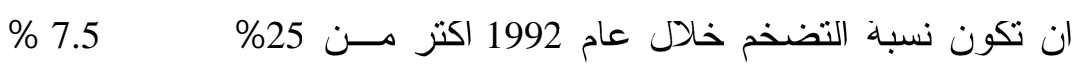

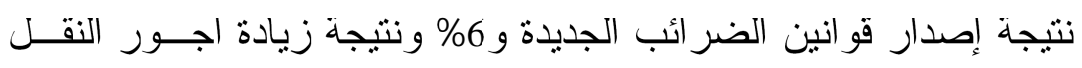

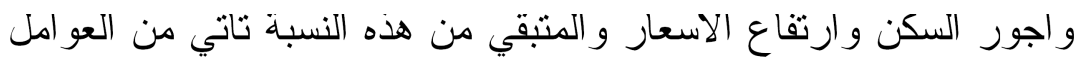

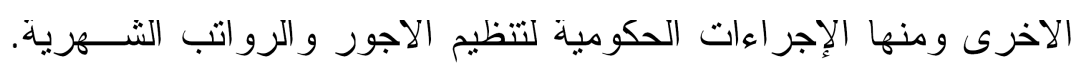




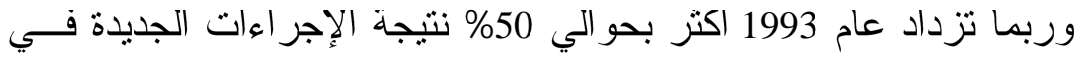

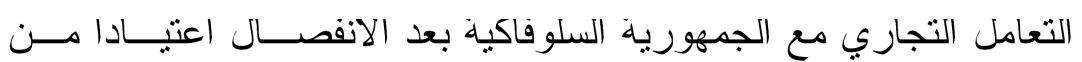
1993/1/1 و التعامل خلالكها ومع البلدان الاخرى وخصوصا في الاستير اد

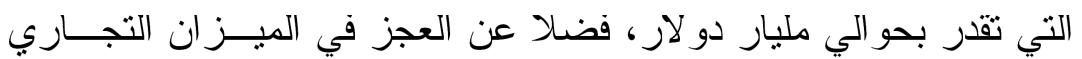
النتيكي (كحد ادنى بنسبة 9\% في الصادر ات وبحدود 0,8 مليار دو لار) ).

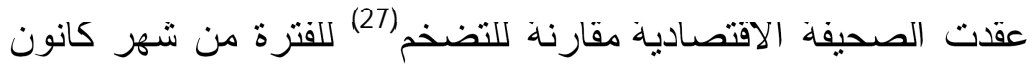
الاول 1992 الذي بلغ حو الي12,7\%مع الفترة فهها من سنة 1991 وبلغت

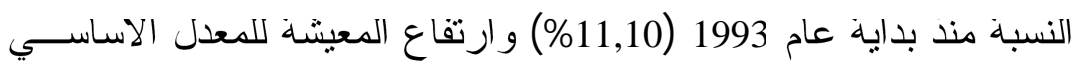
بنسبة 12,9\% للعمال و 12,2\% للفلاحين و12,6\% للمتقاعدين. و استتادا إلى ع

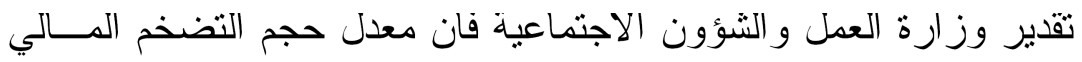

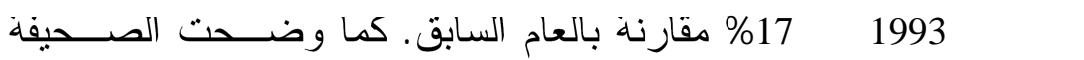
ارتقاع اسعار المنتجات الزر اعية لثهر كانون الثاني من سنة 1993 بنسبة

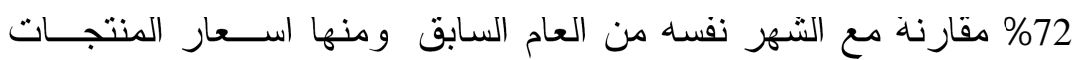

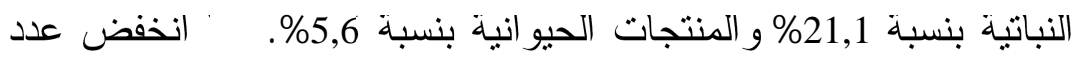
العجول بنسبة 16,8\% لغاية 131/12 /1992 مقارنة مع الفترة نفسها من عام

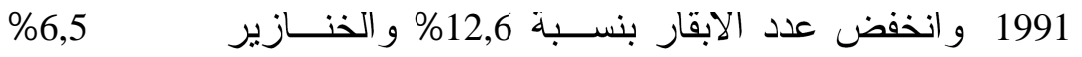

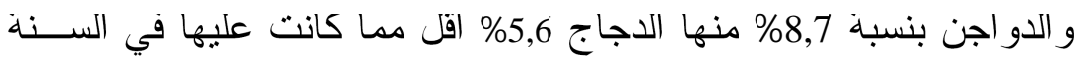
فسها 1991 و الحليب انخفض باقل مما كان سنة 1991 بنسبة 10,3\%. ويمكن المقارنة لفترة النظام الثيوعي وما بعد نجاح الثورة 1989 كان

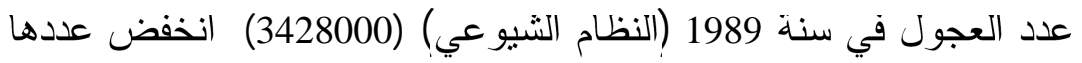
نهايةسنة 1992 إلى (2374000) و الابقار من (1218000) الـــ(183000)

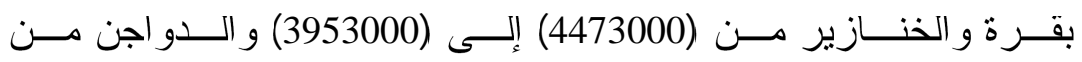
(24726000) الى (21165000) للفترة نفسها (28) 
اما في الحبوب فقد بلـغ حجم الحصـاد لعام 1992 (6,564) مليون طــن

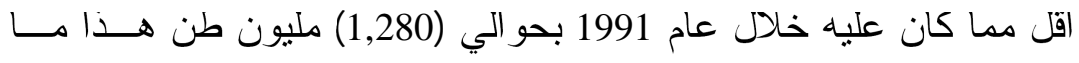

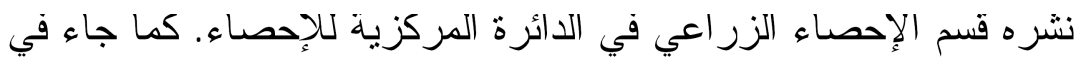

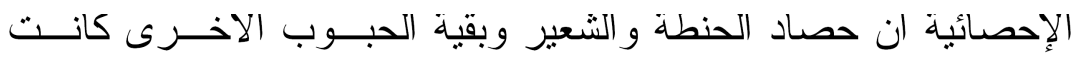
جميعها دون المعدل و المستوى المطلوب و اقل بكثير عن حصـــاد العــام

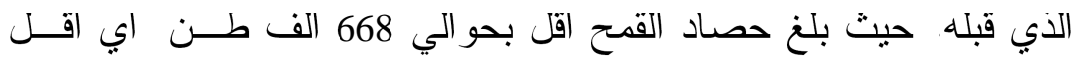
بنسبة 16,4\%، و الشعبر 320 الف طن اقل بنســبة 11,3\% و البطاطـــ 74

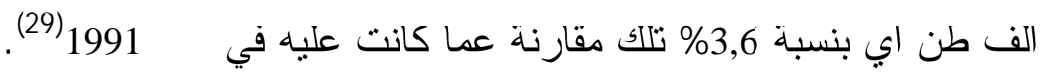

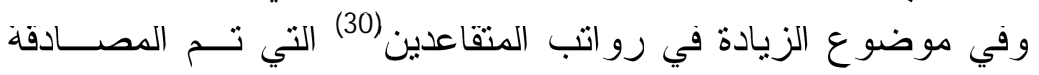

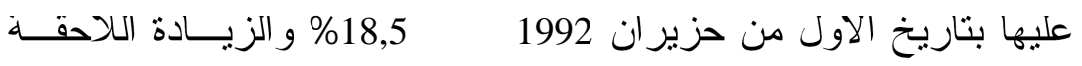

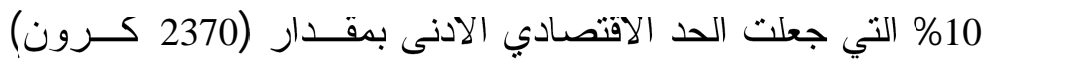

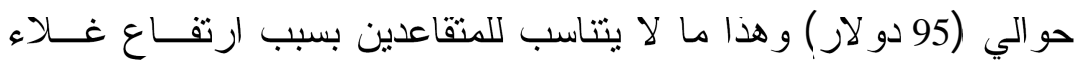

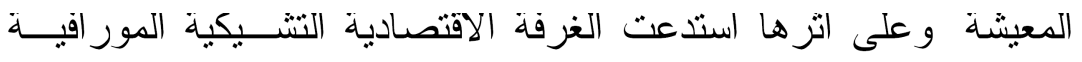

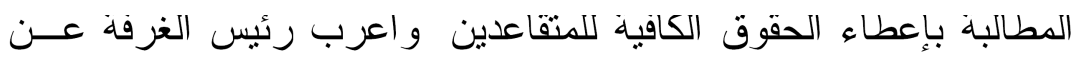

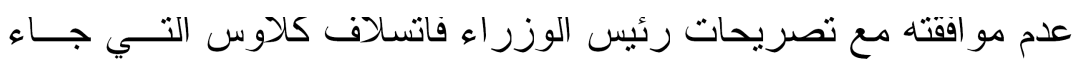

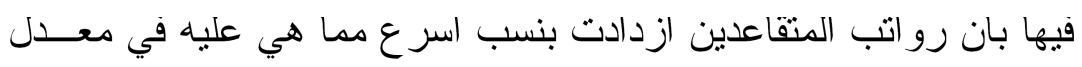
وفي المرفق التجاري (31)، بلغ عدد التجار الجدد العاملين في القطــــاع

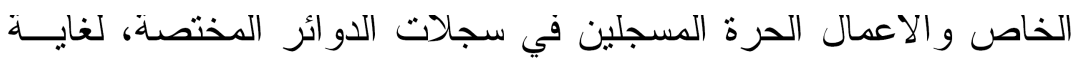
نهاية العام 1992 (1206) شخص وتناتي بر اغ العاصمة في المرنبة الاولى لئل

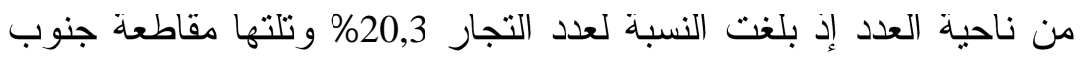

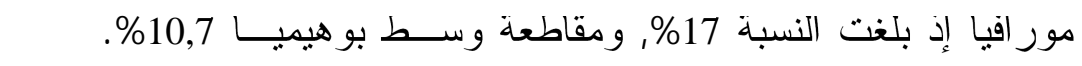

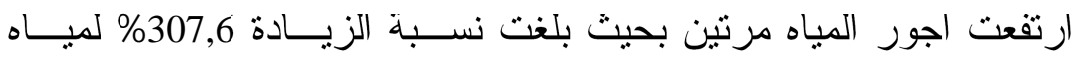


الثُرب في دور السكن و243,4\% للمياه المعاد نكرير ها من القنو ات حسب . ${ }^{(32)} 1991 \backslash 1 \backslash 1$

\section{في مجال الاستتمار ات الاجنبيه}

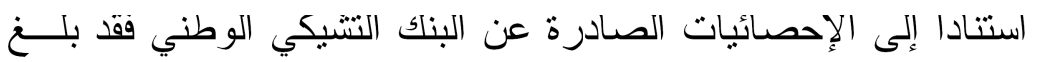

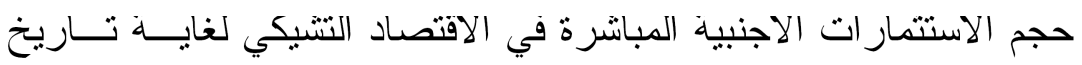
1992\12/31 اليوم الاخير للفدر البة النشيكوسلوفاكية (49,6 مليار كرون) اي ما يعادل 1,7 مليار دولار امريكي. ويعد اكبر حجم من راس المـــال

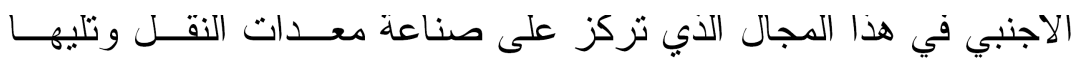

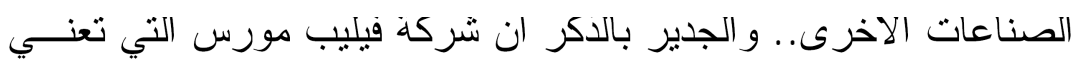

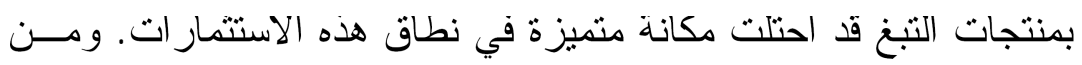

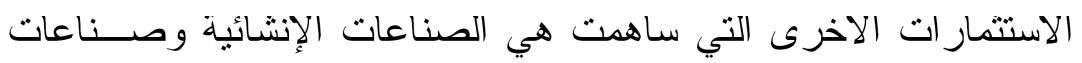

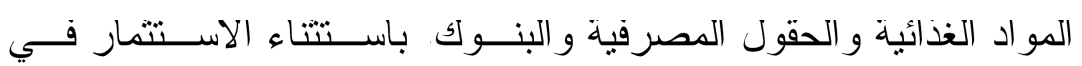

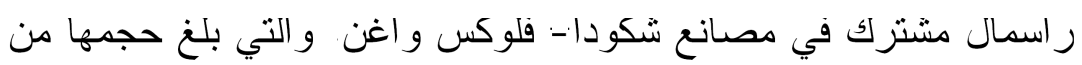
راس المال الاجنبي في سنة 1992 بحدود 30 مليار كرون اي ما يعـادل 1,1 ملبار دو لار .

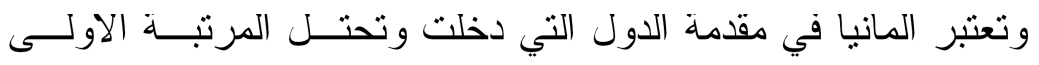

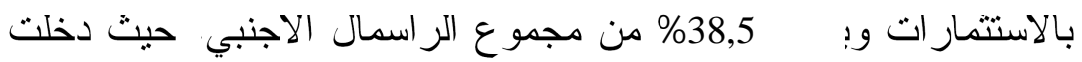

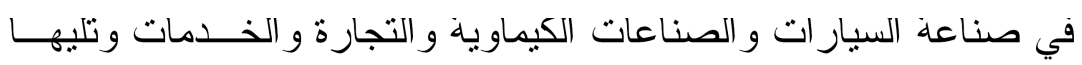

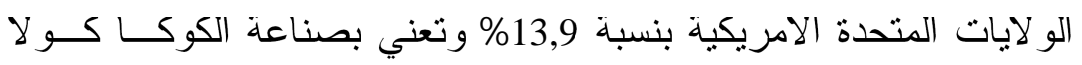

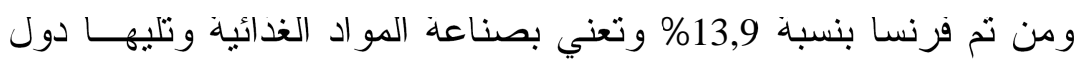
اخرى منل النمسا وبلجيكا و غيرها (33).

اما في قطاع المصارف التجارية الموجودة في الجمهوريـــة التشــيكية

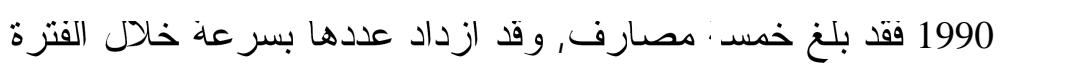

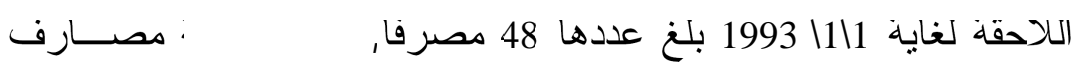




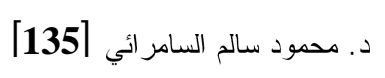

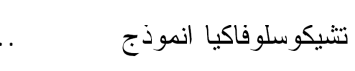

وبنوك بر اسمال اجنبي و 8 مصـارف وبنوك بر اســمال مشـــترك و البقي ـة

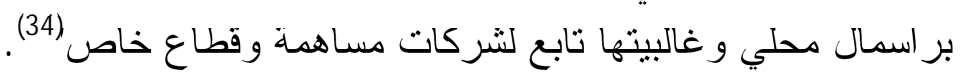

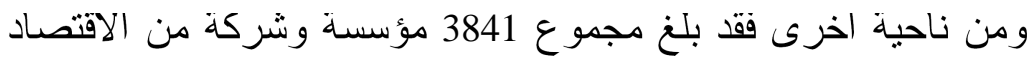

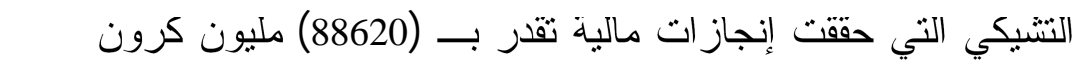

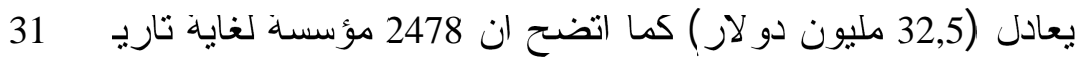

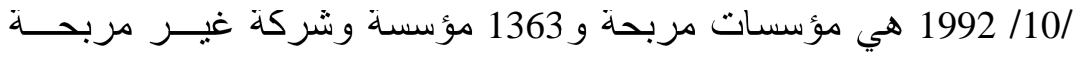

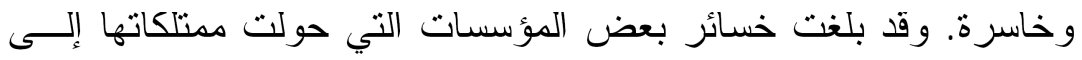
القطاع الخاص بعد بيعها بو اسطة (الكوبونات) بصيغة شركات مســاهمة حو الي 2,8 مليار كرون، في حين حقق قسم اخر من هذه الشركات ارباحا بلغت قيمتها 32,5 مليار كرون (35). الدو لار بساوي حتي في 27 كرون انذاك.

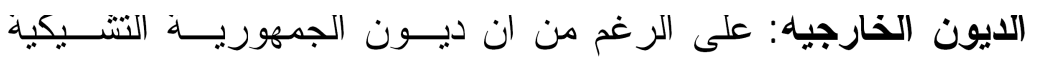

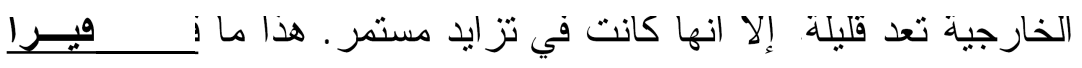

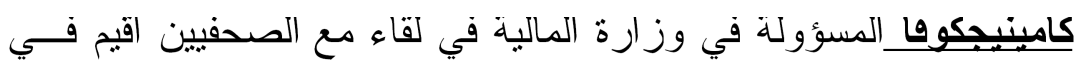
1992/2/21 في العاصمة بر اغ، وقد امتتعت عن ذكر حجم هذه الديون معللة ذلك انه بسبب عدم اكتمال النتائج المالية لميز انية الدولة لعام 1992

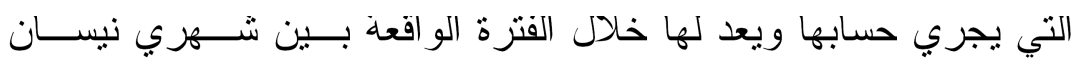
ومايس، وقد اضافت قائلة (إننا نتوقع بهذا الخصوص تنارجا كدا كبير نتيجة

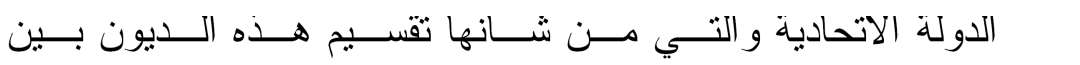

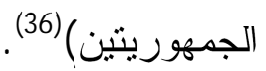


التجارة الخارجيه لجمهوريه التثبك:

الجدول الاتي يوضـح حجم التبادل التجاري للفترة قبل الانفصال وما بعد

الانفصال

\begin{tabular}{|c|c|c|c|c|c|c|}
\hline & \multicolumn{3}{|c|}{ الصادر ات } & \multicolumn{3}{|c|}{ الو اردات } \\
\hline & 1992 & 1993 & 1994 & 1992 & 1993 & 1994 \\
\hline البضائع مصنعه & 2857 & 3927 & 904 & 1065 & 2005 & 437 \\
\hline معدات واليات نقل & 2246 & 3575 & 673 & 4233 & 4591 & 842 \\
\hline منتجات كيماويله & 813 & 1212 & 206 & 1016 & 1532 & 359 \\
\hline زيوت ودهون & 11 & 31 & 4 & 29 & 46 & 10 \\
\hline وهود معدني وزيوت & 502 & 819 & 158 & 1602 & 1411 & 430 \\
\hline مواد خام غير مصنعه & 572 & 760 & 279 & 602 & 639 & 168 \\
\hline المتروبات والتبغ & 64 & 157 & 23 & 139 & 133 & 24 \\
\hline مواد غدائيله وحيو انيه & 714 & 841 & 132 & 632 & 794 & 202 \\
\hline مواد غير مصنفه & $\mathbf{0}$ & 5 & 1 & 5 & 55 & 2 \\
\hline المجموع & 8842 & 12961 & 2840 & 10273 & 12690 & 2782 \\
\hline
\end{tabular}

لقد قدمت غرفة التجارة وشعبة المعلومات التابعـــة لــوز ارة التجـــارة

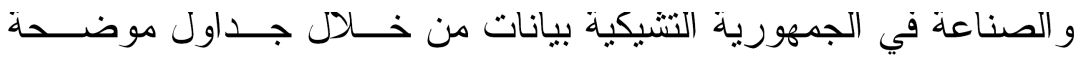

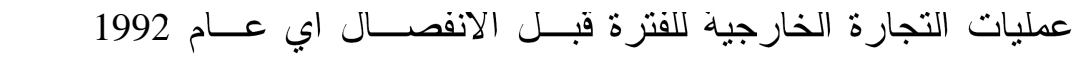

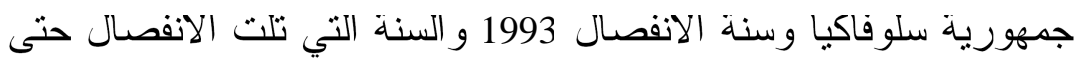
حزير ان عام 1994 نوضـح فيه التباين التجاري للصــــادر ات و الـــــاردات لجمهورية النتيك (بالمليون دو لار) لتنك الفترة. 
اما بشان حجم العلاقة بين جمهورية التتيك وجمهورية سلوفاكيا لفترة

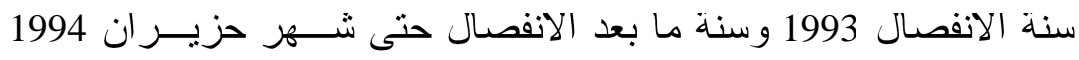

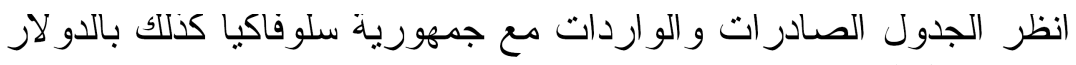
الامريكي (37).

\begin{tabular}{|c|c|c|c|c|}
\hline الصادر ات و الو اردات مع سلو فاكيا & \multicolumn{2}{|c|}{} & \multicolumn{2}{|c|}{ الصادرات 1994} \\
\hline & 1993 & 1994 & 1993 & 1994 \\
\hline & 2696 & 439 & 2161 & 417 \\
\hline
\end{tabular}

\section{الإجراءات السلبيه}

بعد نولى (فاتسلاف هافل) Václav Havel رئاسة الجمهورية كـان من بين الاعمال الني قام بها و التي لم تحضى بارتياح الغالبية العظمى من

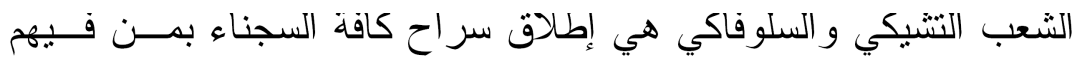

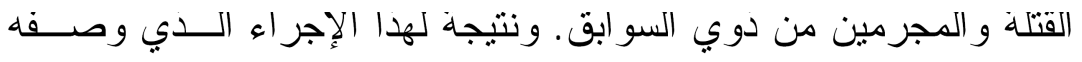

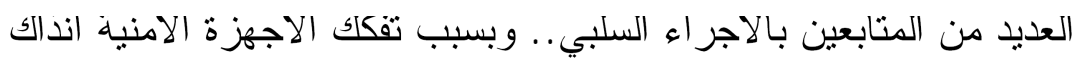

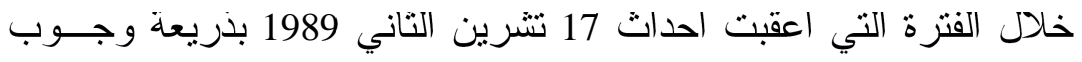

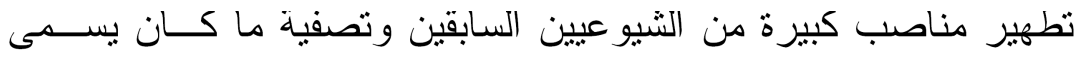

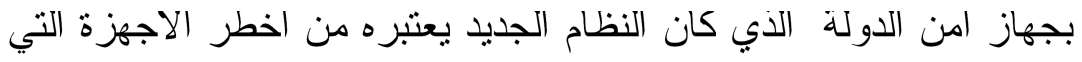

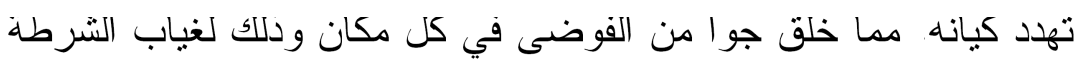
وقلة عددهم الى الحد الادنى، وبات المواطن لا يشعر بالامان و الاطمئنان

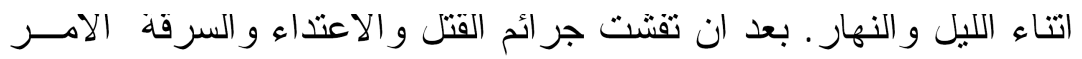

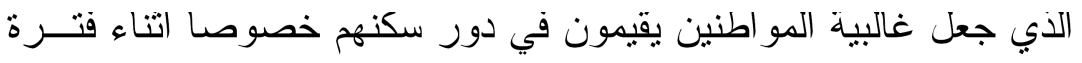

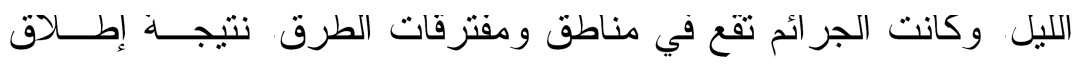

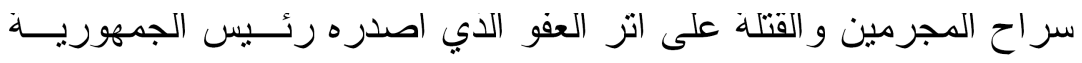




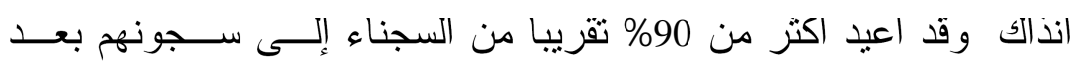

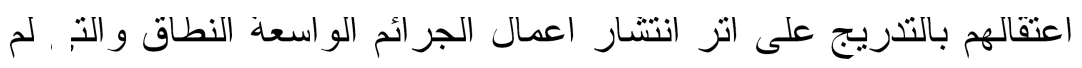
يعرف لها متيل في السابق اي في العهد التشيوعي. وبعــــ إعـــادة بنــاء

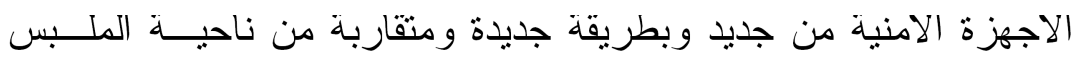

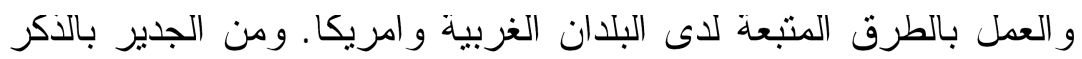

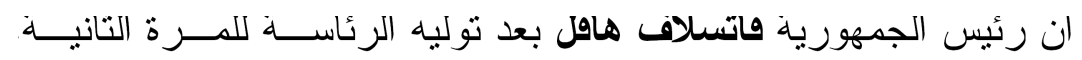
اصدر امر ا من جديد بإطلاق سر اح السجناء، لكن هذه المرة بعدد محدود كما تم دكره من خلال وسائل الإعلام.

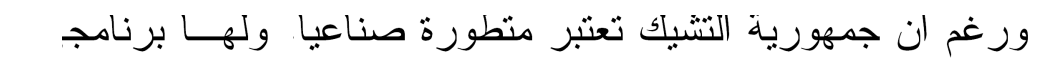

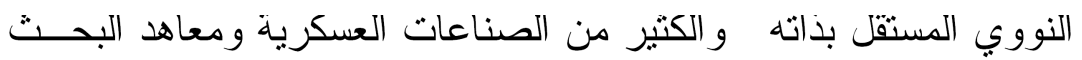

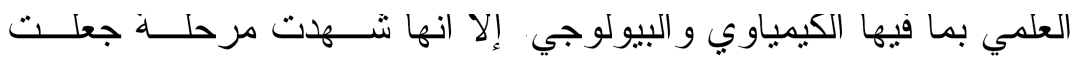

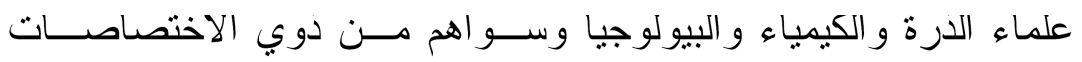

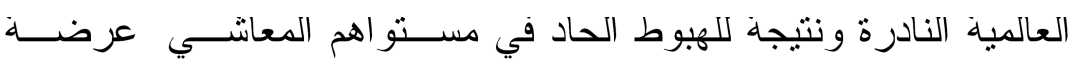

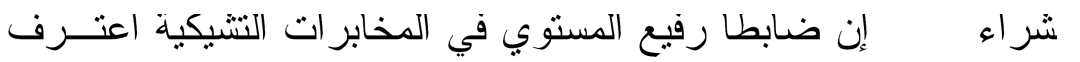
لمندوبي الاعلام (إن كل شيء قابل للشر اء في تشيكيا حينما يتوفر المــال

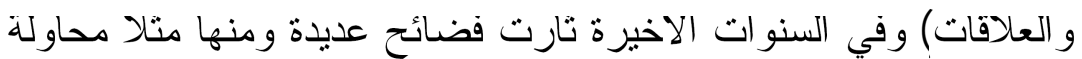

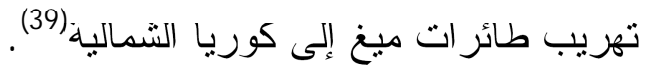

\section{الاعمال الجنائيه و السرفه والجريمه}

لقد استعرضت صحيفة Hospodářské novin (هوسبودا جسكة نوفيني) الاعمال الجنائية واعمال السرقة و الجريمة في الجمهورية التشيكية خلال

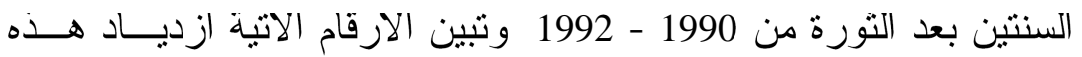

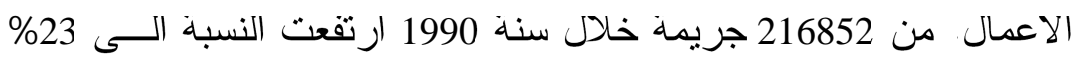
خلالسنة 1991 وفي سنة 1992 بنسبة 37\% علما إن نسبة الجرائم التـي

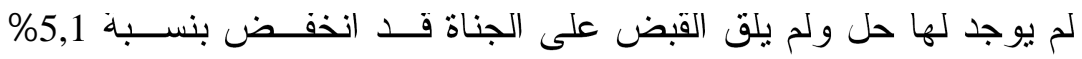




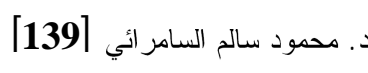

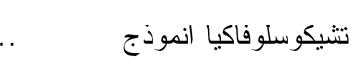

وبلغت قيمة الاضر ار الناجمة عن هده الاعمال بزيادة 2 مليار كرون في

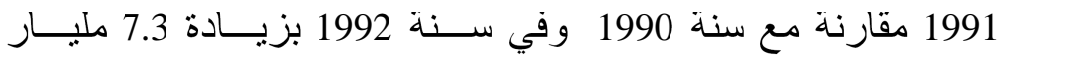
كرون.

فقد بلغت اعمال الجريمة في ســنة 1991 (282998) جريمــة ومنهـــا

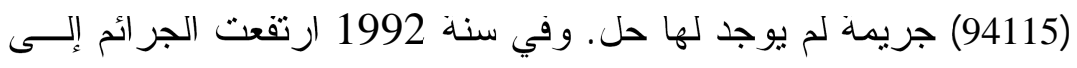

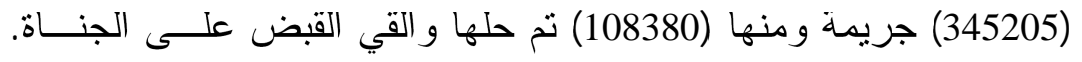
و الجدول الاتي يوضح صورة الاعمال الإجر امية التي حدتت خلال فترة

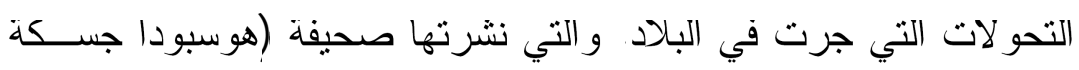

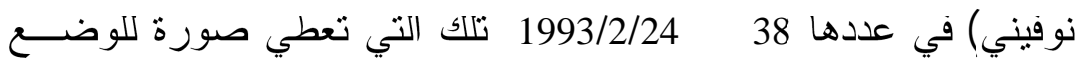

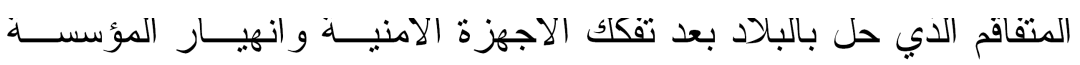

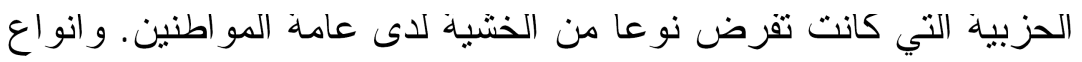

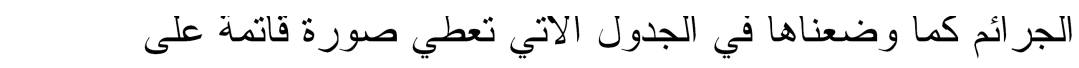

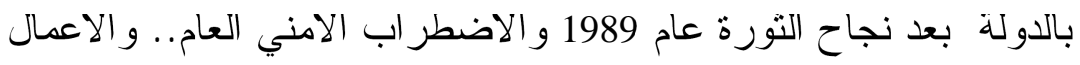

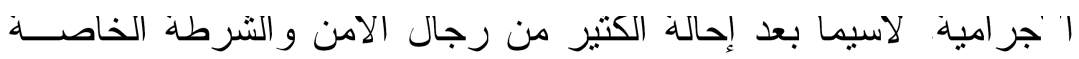

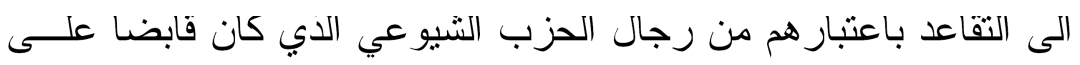

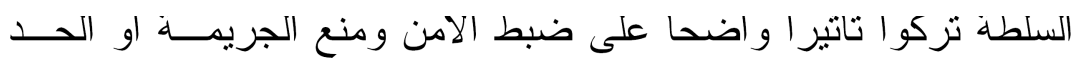

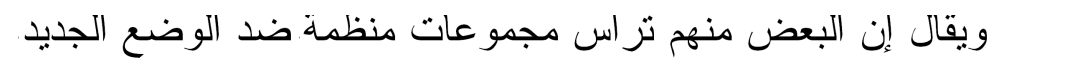
حسب راي الصحيفة(40). 
در اسات إقليمية 6 (19) $[140]$

الجرائم للقترة من التورة المخمليه حتى اتفصال التشيك والسلوفاك

1993/1/1 - 1989

\begin{tabular}{|c|c|c|c|}
\hline عدد الجرائم 1992 & عدد الجرائم & عدد الجرائم & انواع الجرائم \\
\hline $\begin{array}{l}314526 \\
82589 \\
\% 26,3\end{array}$ & $\begin{array}{l}258020 \\
72513 \\
\% 28,1\end{array}$ & $\begin{array}{l}192492 \\
62233 \\
\% 32,3\end{array}$ & تم تسويتهائم العامه ومنها الجرائم التـــي \\
\hline $\begin{array}{l}18571 \\
12955 \\
\% 69,8\end{array}$ & $\begin{array}{l}18715 \\
13123 \\
\% 70,1\end{array}$ & $\begin{array}{l}17812 \\
12644 \\
\% 70,1\end{array}$ & 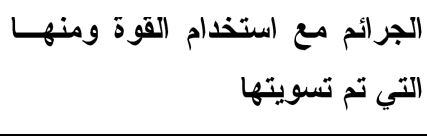 \\
\hline $\begin{array}{c}258 \\
219 \\
\% 84,9\end{array}$ & $\begin{array}{c}194 \\
174 \\
\% 89,7\end{array}$ & $\begin{array}{c}212 \\
184 \\
\% 86,8\end{array}$ & 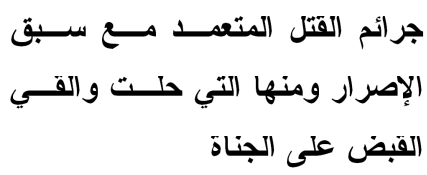 \\
\hline $\begin{array}{c}3915 \\
1325 \\
\% 33,8 \\
\end{array}$ & $\begin{array}{c}4142 \\
1515 \\
\% 36,6\end{array}$ & $\begin{array}{c}3855 \\
1475 \\
\% 38,3\end{array}$ & جرائم السرهه منها التي تم حلها \\
\hline $\begin{array}{c}8093 \\
6200 \\
\% 76,6\end{array}$ & $\begin{array}{c}8760 \\
6618 \\
\% 75,5\end{array}$ & $\begin{array}{c}8819 \\
6770 \\
\% 76,8\end{array}$ & 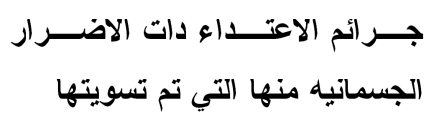 \\
\hline $\begin{array}{c}1493 \\
1464 \\
\% 98,1\end{array}$ & $\begin{array}{c}1329 \\
1320 \\
\% 99,3\end{array}$ & $\begin{array}{c}1052 \\
1047 \\
\% 99,5\end{array}$ & تمر ائم مهاجمه رجال الشرطه منها \\
\hline
\end{tabular}

\section{الامن السلبي}

وفق ما بذكر مدير مركز المخدرات بيرجي كوموروس يوجــد ف مي

تشيكبا ما بزيد علي 15 عصسابة منظمه من اوروبا الشرقية و البلقان، بدءا

بمافيا المخدر ات، و انتهاء بالعصـابات الروسبة المتخصصسة فــي البخـــاء 
وتجارة السلاح. و هدا ما يسهل الحصول على انواع من اللَسلحة المختلفة

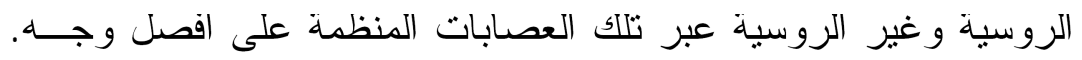

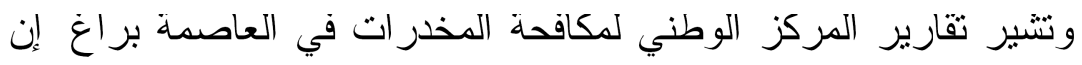

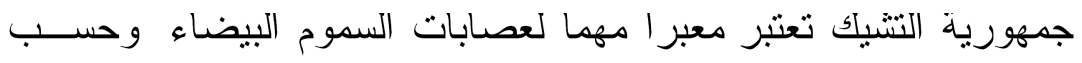

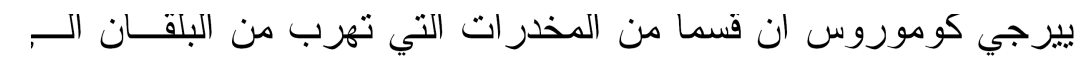

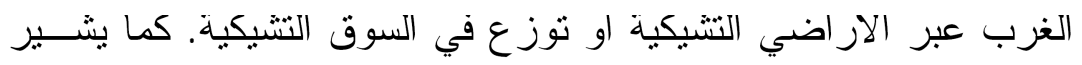

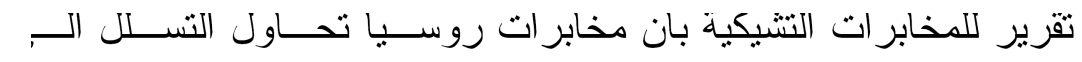

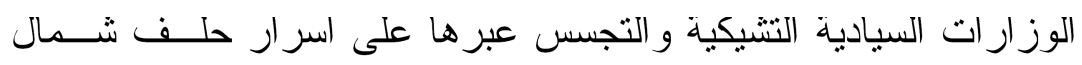

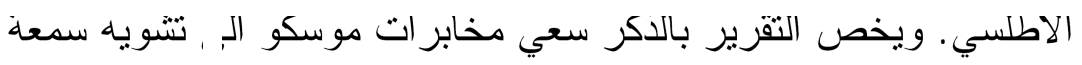

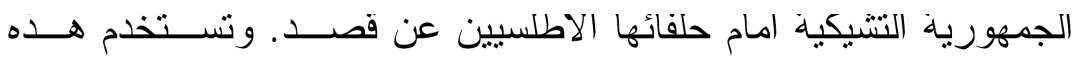

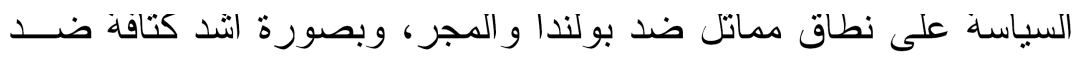

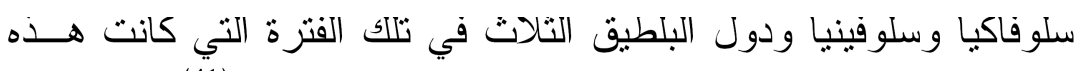
الدول تبدل جهودا محمومة للالتحاق بحلف شمال الاطلسي (41).

جمهوريه التثيك الحديته

جمهورية النتيك الحالية ار اضي مغلقة في وسط اوروبا، تشمل مسنـ

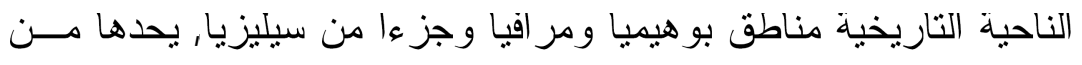

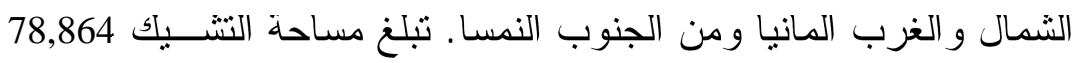

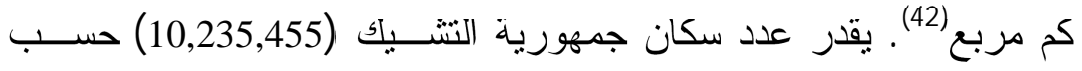

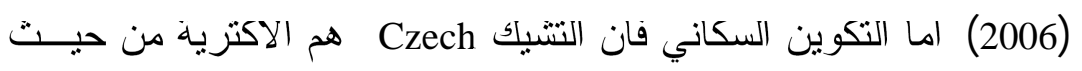

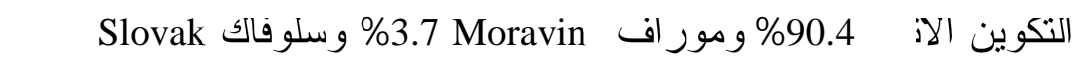

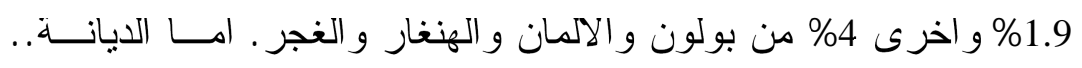

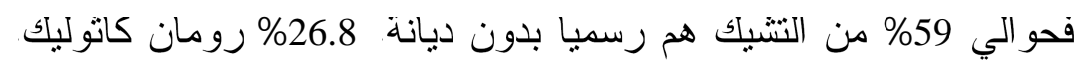

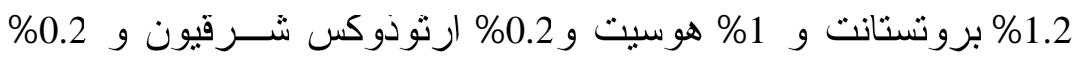


يهود 2.8\% ديانات اخرى. وكانت الطو ائف الدينية ممنوعة ايــام الحكـم

$$
\text { الشيو عي للبلاد (43). }
$$

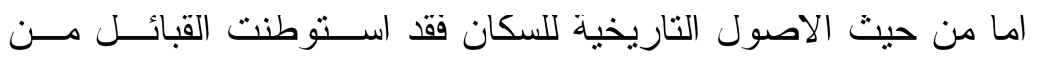

الاصل السـالفي الار اضي النتيكية وهي المر اقيا و البوهيميا، وقد كــــانوا

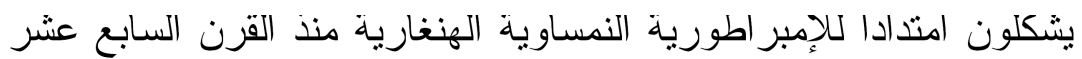

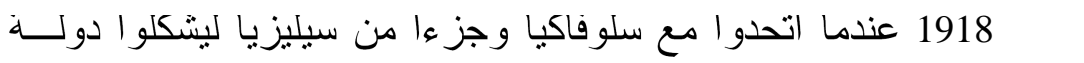

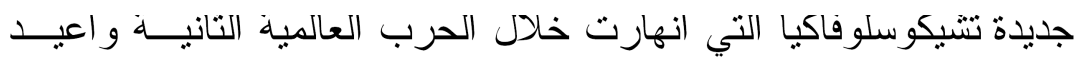
تشكيلها بعد انتهاء الحرب عام 1945. و على اتر نجاح التورة المخمليـــة

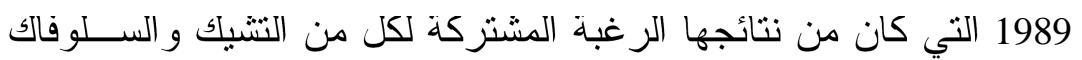
بالافصل، الذي حدث في 1993/1/1 لتصح كلتا الدولتين مستقلتين. لقد شرع قادة الدولة التشيكية منذ وقت مبكر بعد نجاح التــورة 1989 الاخذ في بناء المؤسسات السياسية وفي مقدماتها وضع دستور جديد للبلاد

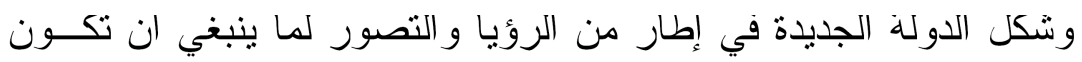

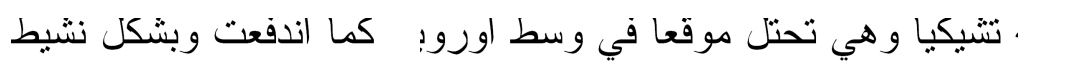

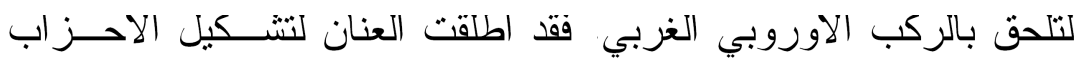

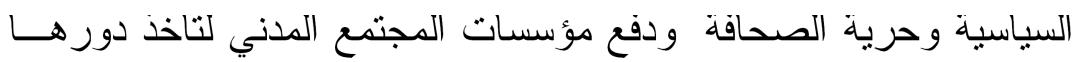

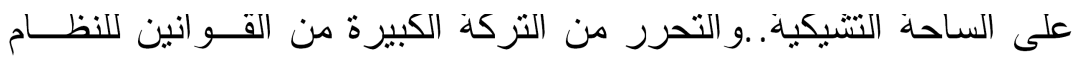

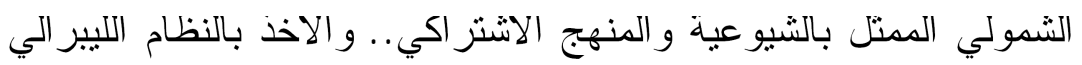

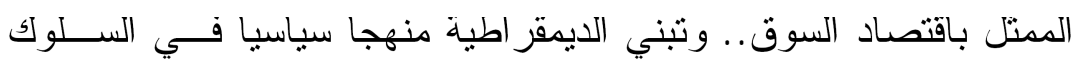

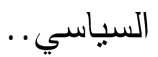

\section{النظام السياسي لجمهوريه التشيك}

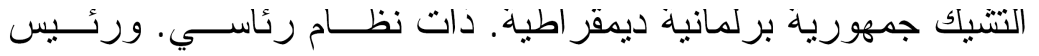

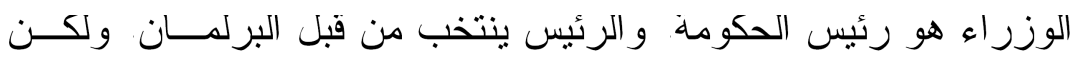

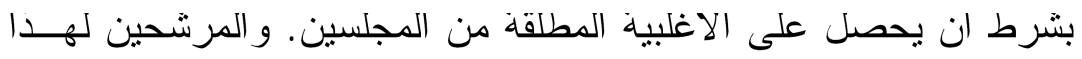


المنصب يجب ان يرشحو ا من قبل عشرة نواب او اعيان على الاقل و الا

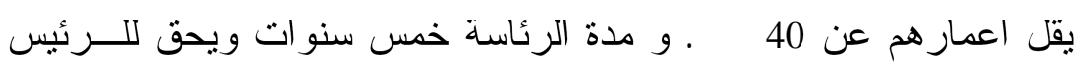

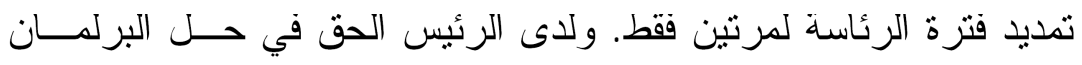

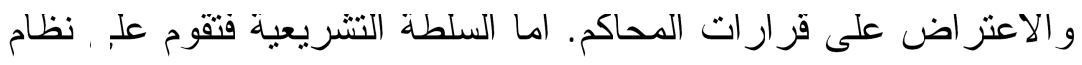

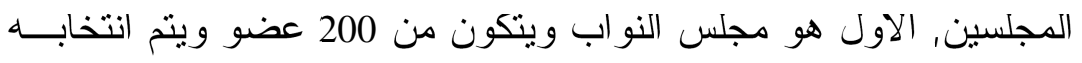

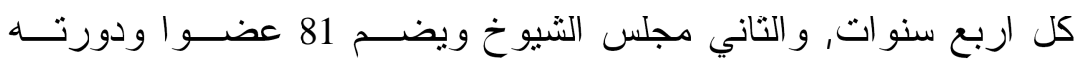

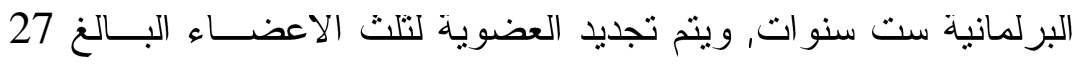

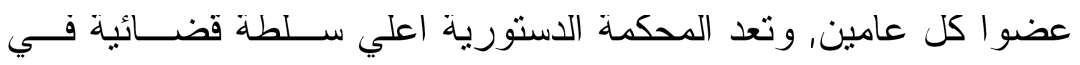
البلاد. اما البرلمان التشيكي فيتكون من مجلسين: مجلس النواب ومجلس

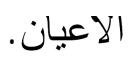

ويتكون النظام القضائي التنيكي من المحكمة الدستورية ونظام قضائي

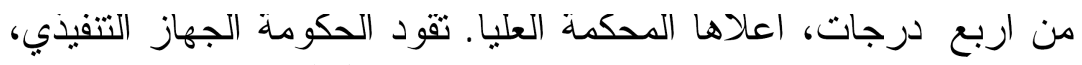
الدي تتبعه إدار ات المناطق التشيكية الاربعة عشر (44).

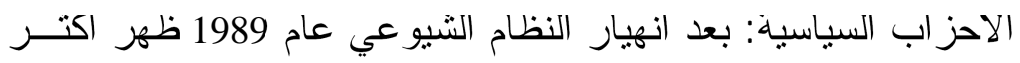

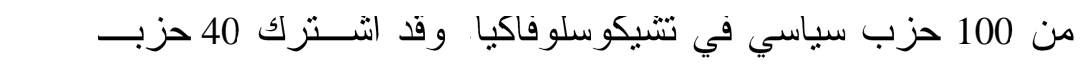

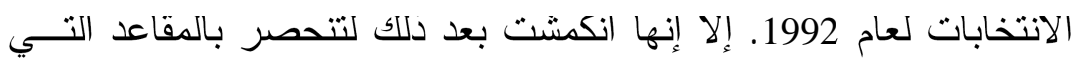

$$
\text { وصلت الى البرلمان }
$$

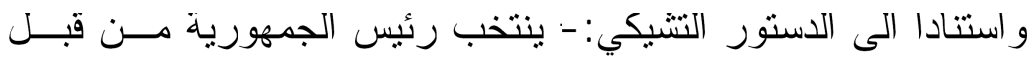

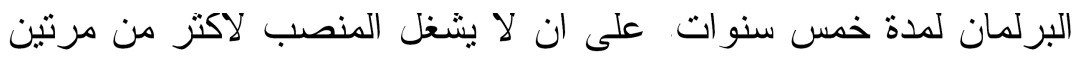

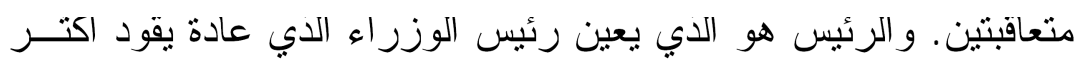
المقاعد في البرلمان وهو يمتل الحكومة. لئن 
1. السياسه الخارجيه

بعد الانفصال عام 1993، جرت الانتخابات في جمهورية النشيك وحاز

حزب كلاوس Václav Klaus الذي اصــبح رئيســـا للحكومـــة برئاســـة

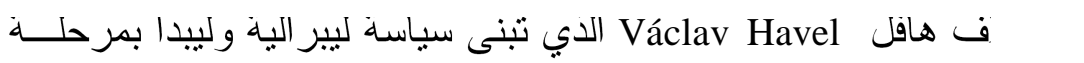

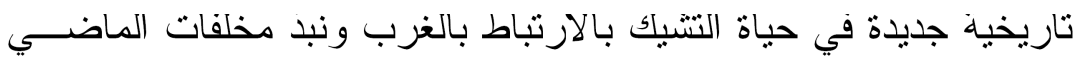

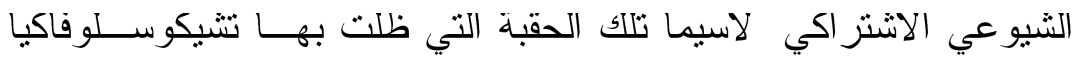

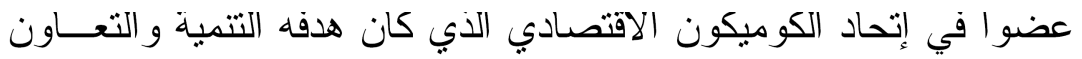

الاقتصادي بين دول الكتّة الاشتر اكية لدول اوروبا النشرقية، حينها كانت

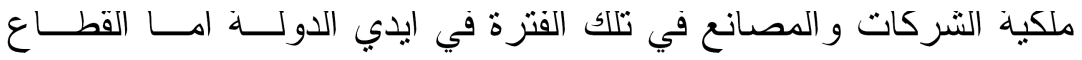

الخاص انداك فلم يكن منو اجدا من الناحية العملية. لذا جاء السعي من قبل لـاهي

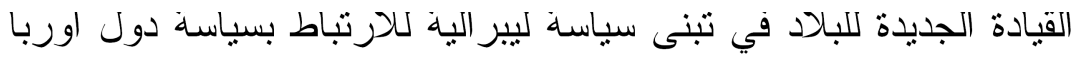

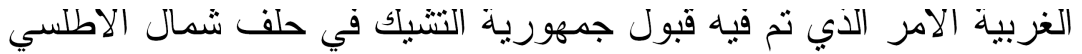

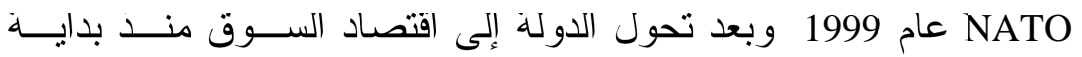

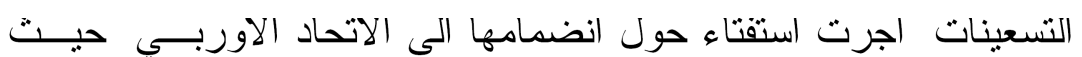

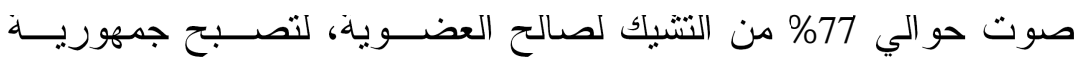

التشيك عام 2004 احد اكتر اقتصاديات اوروبا نمو ال(45). فقد بلغت نســبة

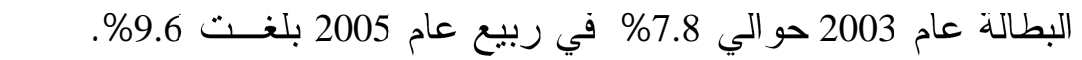

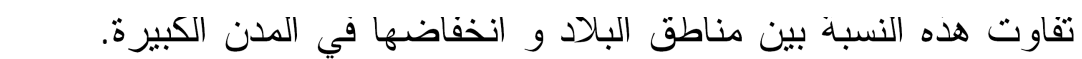

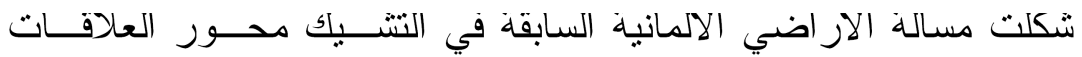

التشيكية الالمانية. حتق إن وقع البلدان اتفاق مصالحة عام 1997 منهيـين

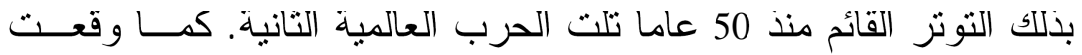

التشيك اتفاقا اخر ا مع روسيا عام 1993. 


\section{قييم تجربه التحول السياسي حق 2008}

لقد حققت التجربة التشيكية نجاحا في التحول الديمقر اطي، مند نجـــــاح

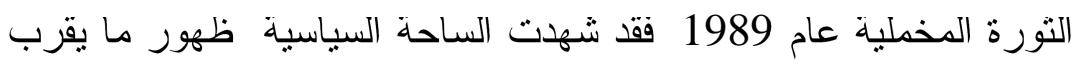
من 100 حزب وتنظيم وحركة ور ابطة سياسية، اشترك في الانتخابـات التي جرت في البلاد عام 1992 ما يقرب من 40 حزبا ونكوينا سياسيا،

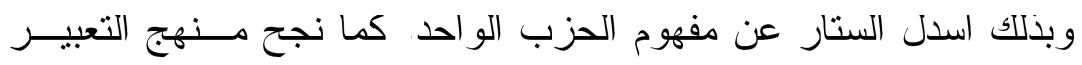

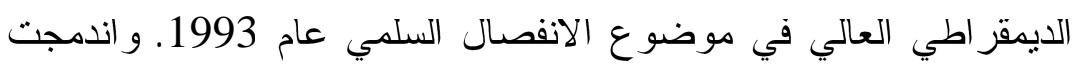
التجربة الديمقر اطية بكل ما يجري في دول اوروبا الغربية، بدا بالانفتاح

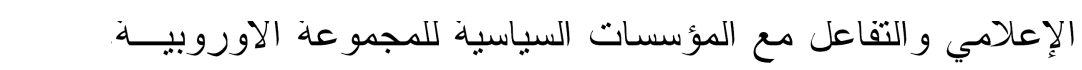
حدثت في البلاد وبخاصة في جمهورية التشيك، حركة اصلاحية شــاملة،

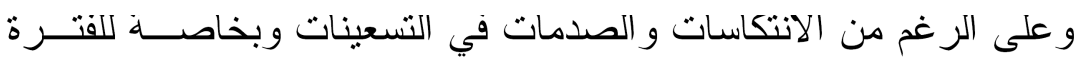

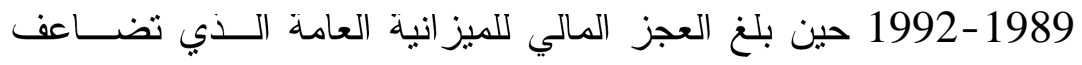

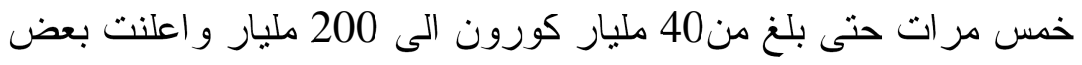

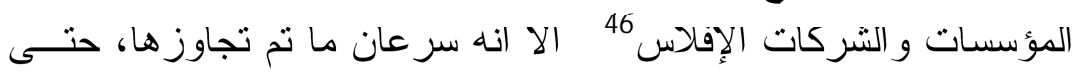

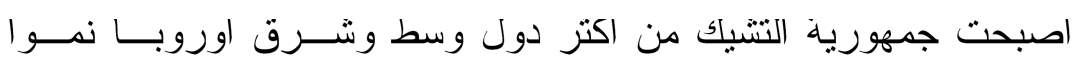
اقتصاديا ويمكن الإشارة الى انخفاض نسبة التضخد، التي لم تتجاوز 3ن مند عام 2000، حتق 2007، ونما الناتج المحلي من 3 مادئ 75 مليار دو لار

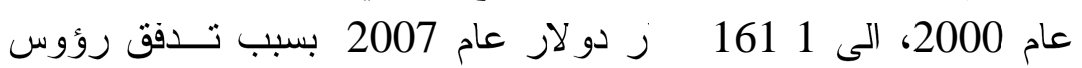

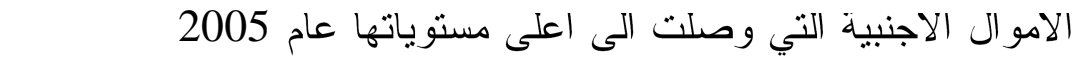
12 مليار دو لار وبخاصة بعد انضمامها الى الاتحاد الاوروبي عام 2004

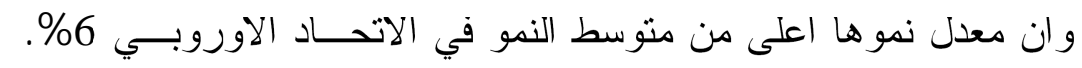

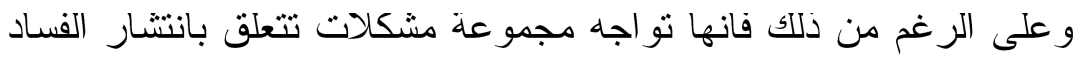

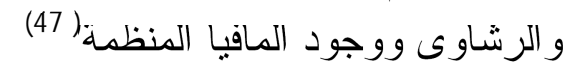


إلا ان التحول التدريجي اخد بعدا سياسيا تصـاعديا تجـــاه الاحــزاب

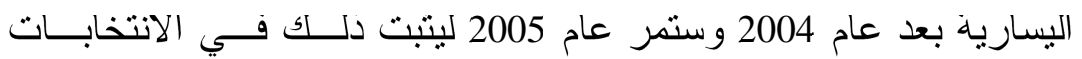

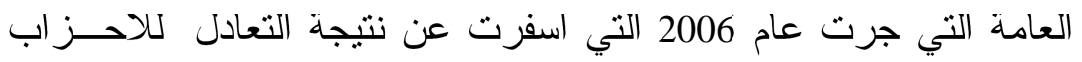
اليسارية المعارضه، ومن تم انقسم مجلس النواب في البرلمان إلى نصفين

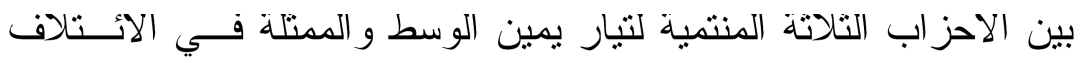

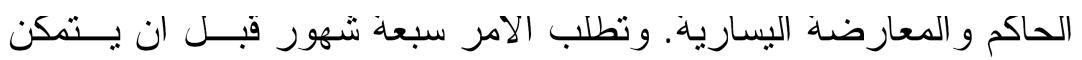
الائتلاف من الحصول على صوتين من المعارضة وتمرير اقتر اع بالتقة

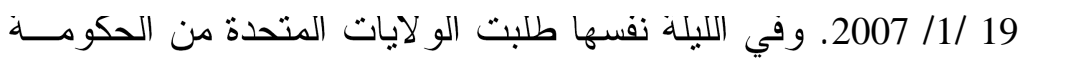

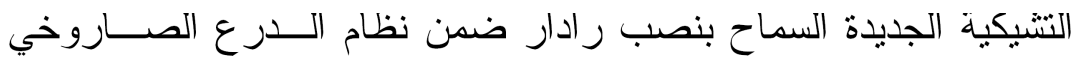

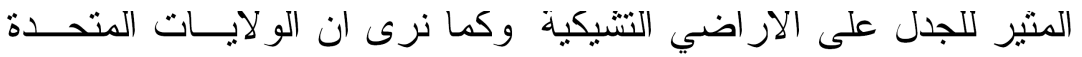

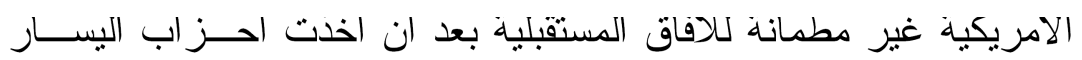
مساحتها التي باتت تتسع في الوسط الجماهيري، الامر الذي اسرعت فئه فيها لتوقيع الاتفاقية الثنائية مع الحكومة النشيكية.

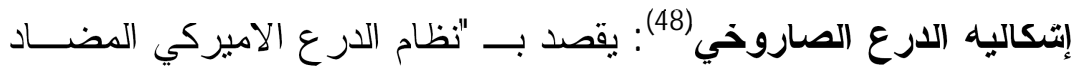
للصو اريخ" بناء شبكات حماية مكونة من انظمة صو اريخ ارضية، مستتدة على نقاط ارتكاز جغر افية عدة، قادرة على إسقاط اي صاروخ باءل بالســتي

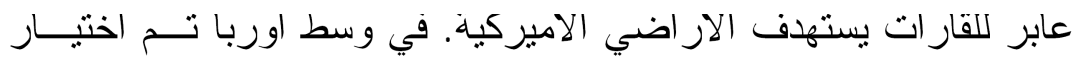
التشيك من قبل الإدارة الامريكية، بسبب منانة العلاقة، ويجمع المر اقبون الإني على وجود انعكاسات لهذا النظام تؤثز على التوازن الإســـز اتيجي بــين

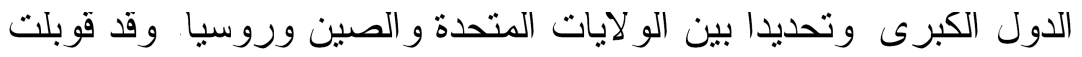

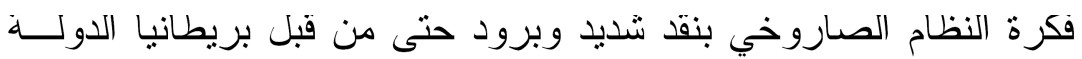
الاقرب سياسيا و إستر اتيجيا للو لايات المتحدة.

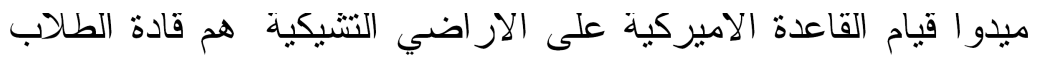

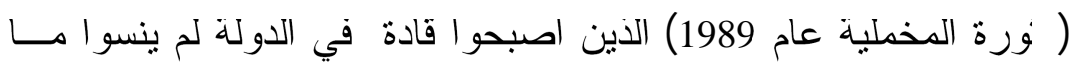


قدمته الإدارة الامريكية لنجاح تورتهم فهم يرونه واجبا اخلاقيا وعرفانـــا

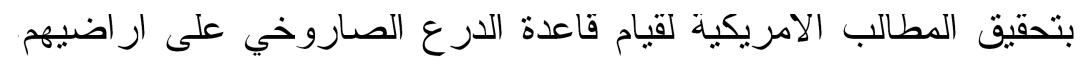

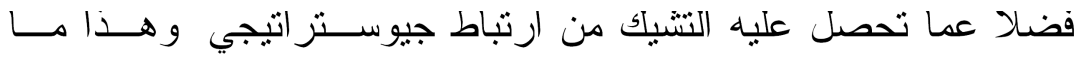

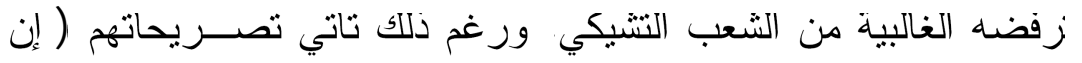

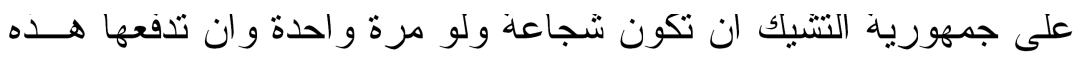

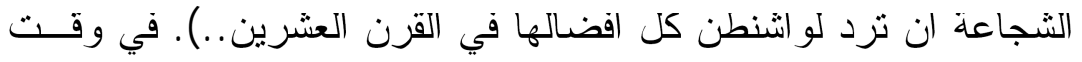

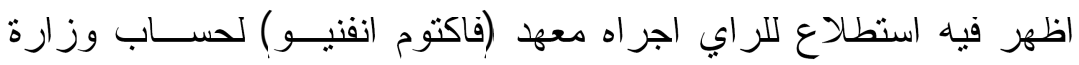

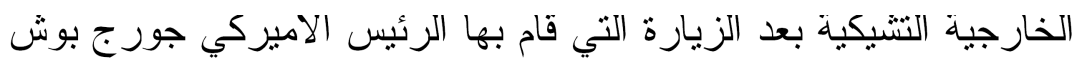

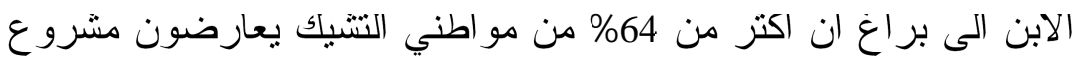

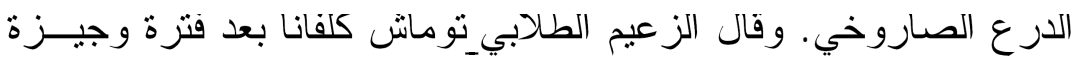

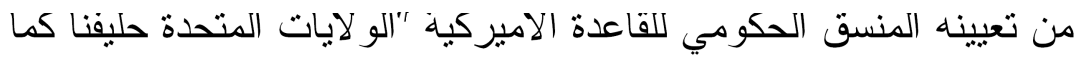

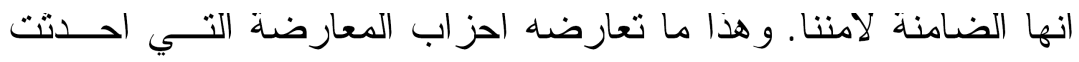

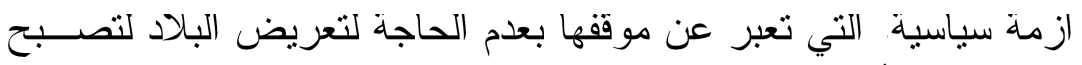

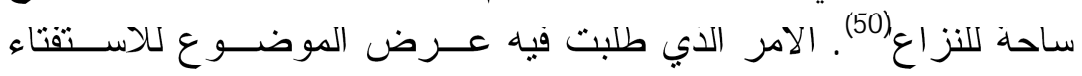
الشَعبي.

\section{جمهوريه التشيك والآدماج الغربي}

خلال عقد واحد بعد التورة انتقلت جمهورية التشيك من دولة شيوعية

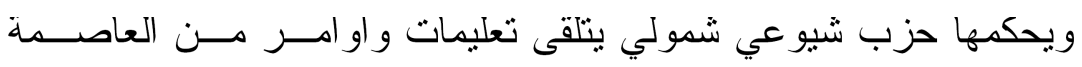

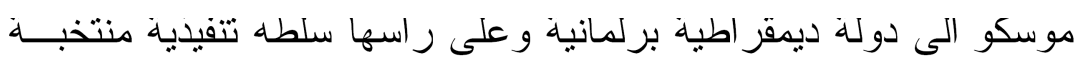

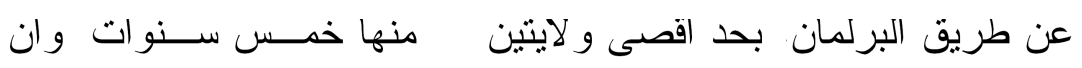

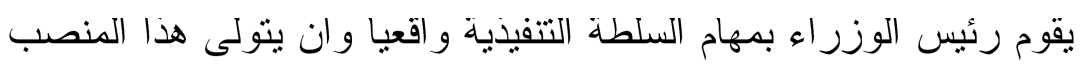
رئيس الحزب الدي يحصل على اكتر المقاعد في مجلس النو اب. 
ولم تكن السياسة فقط التي تغيرت جذريا في جمهورية التشيك, فالدولة الاشتر اكية التي كان يقوم اقتصادها على اساس التخطيط المركزي وتحكم

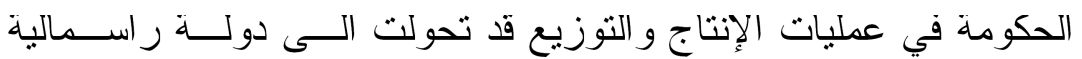

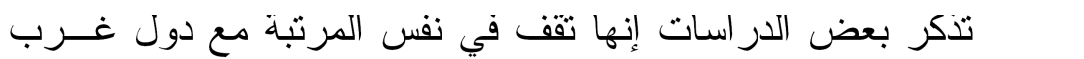
اوروبا وشمال امريكا و استز اليا، وخلال عقد واحد تمت خصخصة 3000 شركة، وتمكنت من جذب استنمار ات اجنبية هائلة (51).

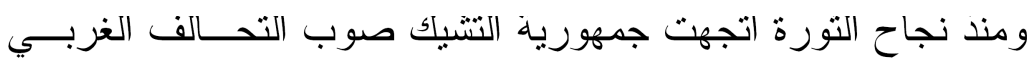

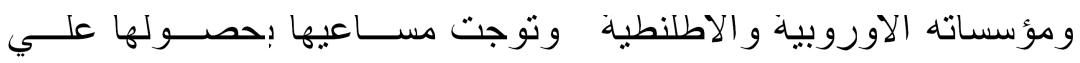

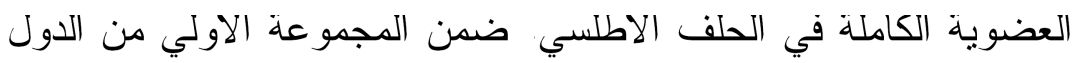

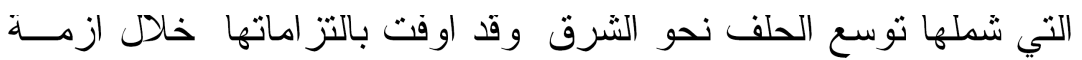
كوسوفو، كما شاركت مع بقية القوات الاطلسية في عمليات حفظ الســلام في البلقان كما قامت بالتعديلات المطلوبة في القوات المسلحة التشــيكية،

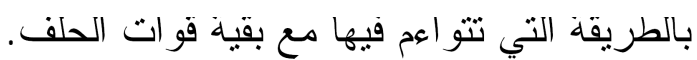

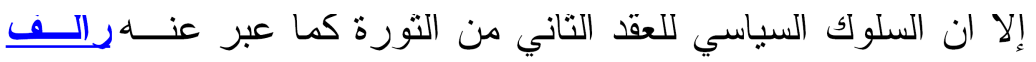

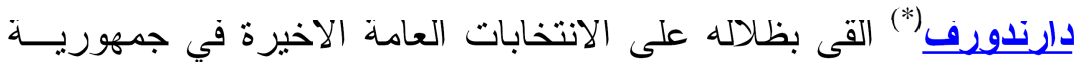
التشيك 2006، فقد انتهت إلى طريق مسدود، حيث نجح كل من اليســار

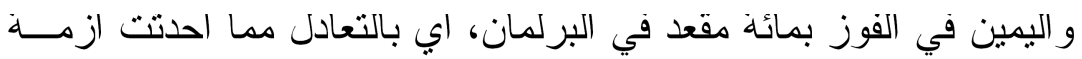

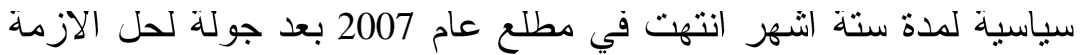

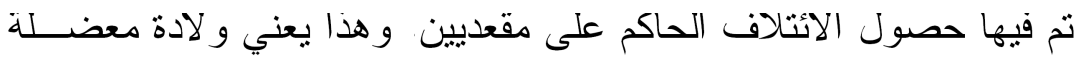

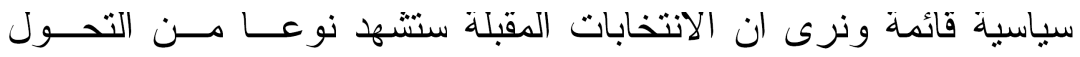

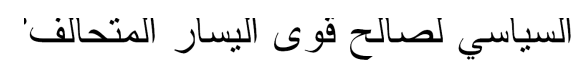




\section{دور اليهود وي السياسه التشيكيه}

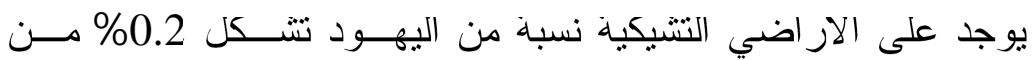

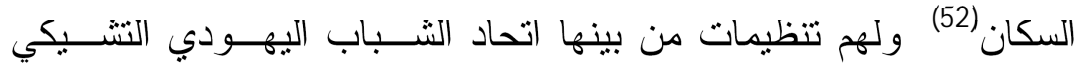

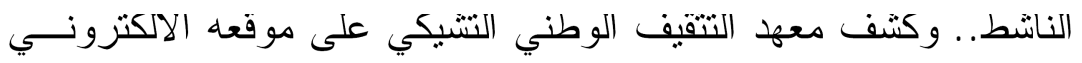

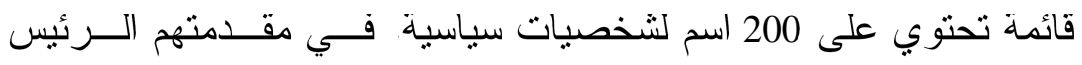
التشيكي فاتسلاف كلاوس و الرئيس السابق للبلاد فاتسلاف هافل ومن بين

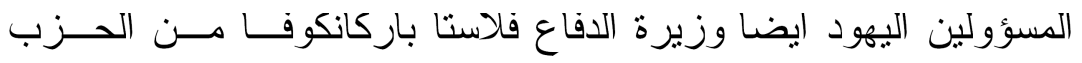

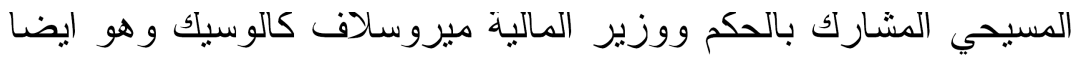
من الحزب نفسه وديفد راث وزير الصحة السابق و النائب في البرلمـــان

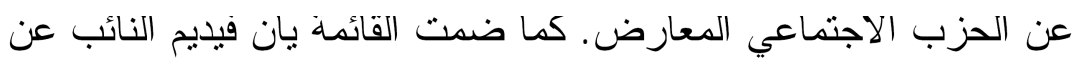

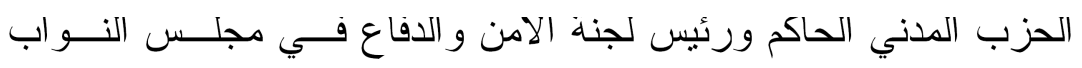

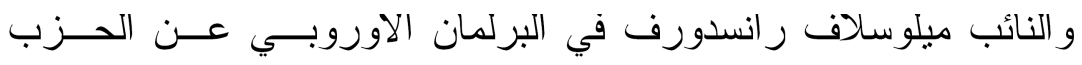

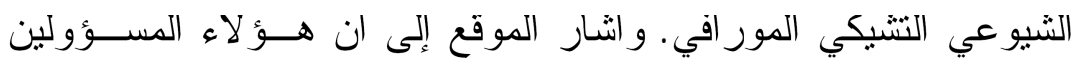

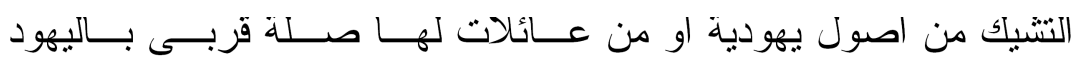

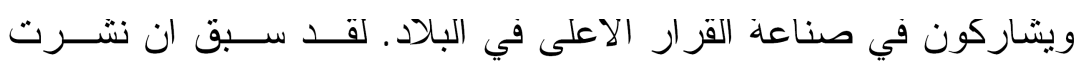

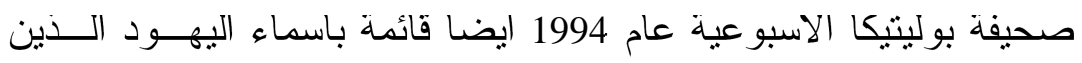

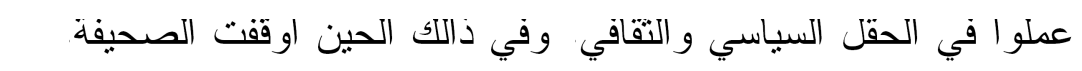
حكم على رئيس تحريز ها بالسجن المشروط لمدة سبعة اشهر مع الشئ حرمانه

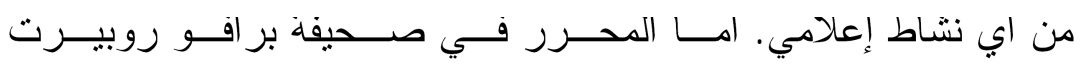

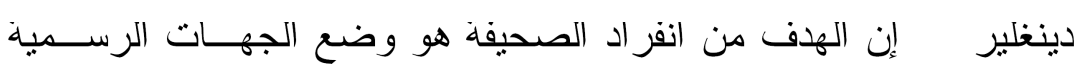

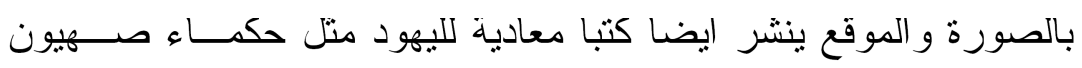

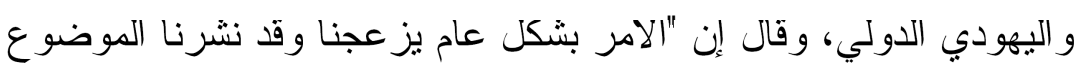

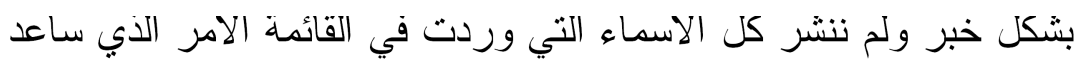

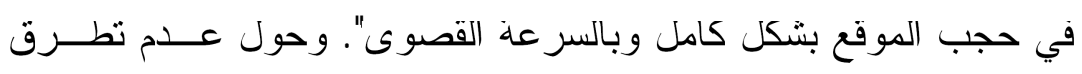


وسائل الإعلام المحلية لهذا الخبر اشتار دينغلير إلى انه ليس لديـــه فــــرة

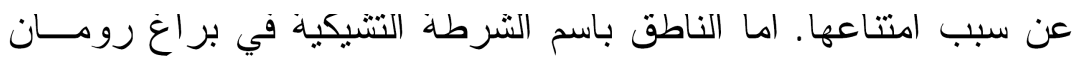

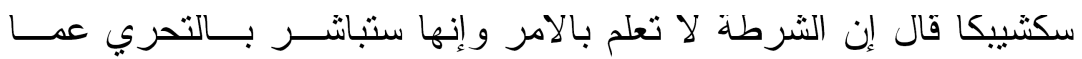

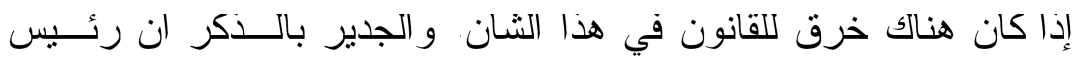

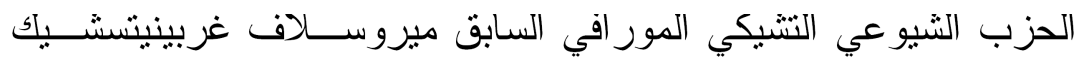

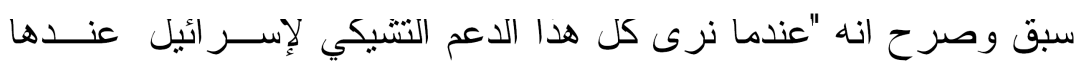

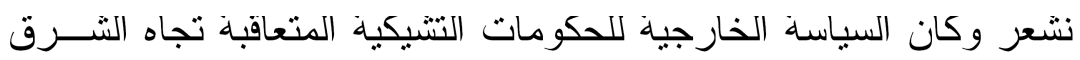

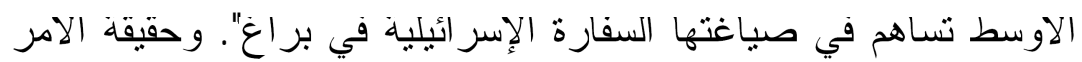
إن التفسير و التحليل المنطقي لحجم ونوعية العلاقة التشيكية الإســر ائيلية

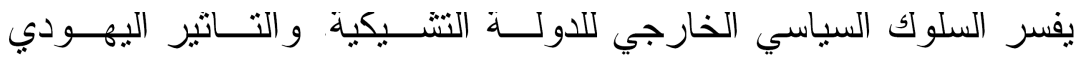

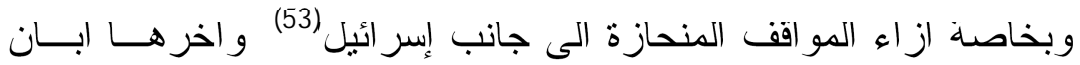
الحرب على غزة 2009 وتصريحات النشيك من خلال ترؤسها للمجمو عة إنة

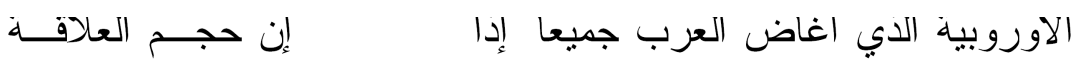

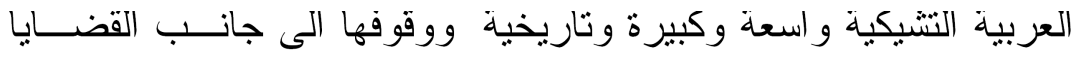

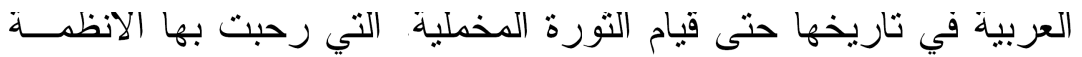

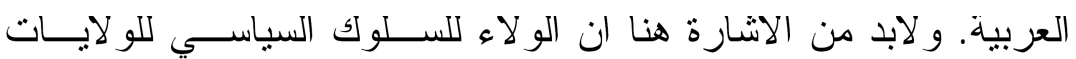

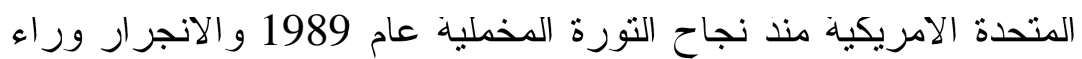
الإستر اتيجية الامريكية كان عاملا محركا(الو لاء و الطاعة) وهذا ما يفسر تاثير السلوك السياسي لليمين المتطرف في الإدارة الامريكية على الكتير من الدول ومنها التشيك.

\section{تجربه التتيك (التحول والاتدماج الغربي)}

بعد الانضمام الى الاتحاد الاوروبي، اندفعت جمهورية تشيكيا، في بناء

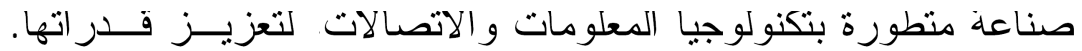
فالتغيير الجذري للإصـلاح الاقتصادي الذي جاءت به التورة المخمليـة، 
وبخاصـة بعد تدفق الر اسمال الاجنبــي الاســتتماري، وتحســن الإنتـــاج الصناعي واستمر ار التتمية المستدامة، حتى اصبحت و احدة مــن اكتـر التر الدول رخاء واستقر ار ا بين اقر انها من الدول التي نفضت غبار الثَيوعية

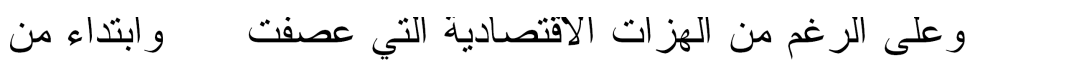

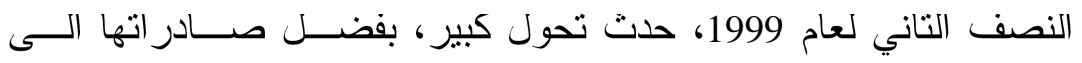

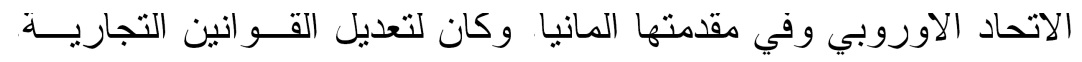
وتدفق الاستتمار الاجنبي حتى وصل الى 5 مليار ات دو لار عــــام 2001.

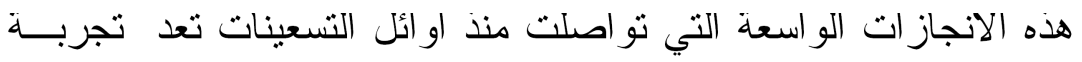

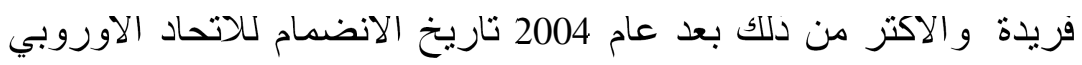
هذا الانضمام قدم للنشيك فو ائد مختلف في المجالات السياسية الاقتصادية

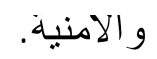

- تدفق الاستمار ات الاوروبية، وتحسين فرص العمل، التجارة وتطوير

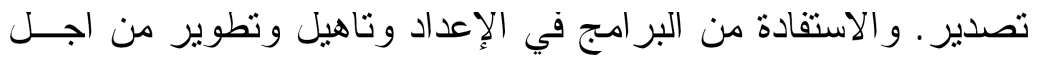

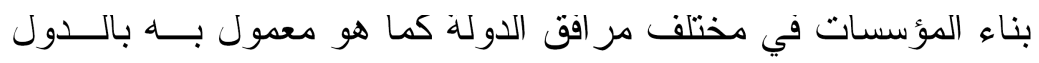

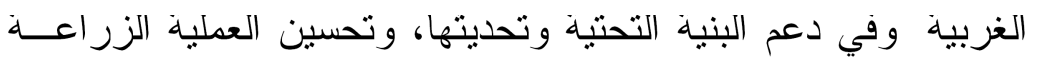
وقد حصلت نشيكيا من خلال هذه البر امج على ما يقارب المليار يورو قبل الانضمام، حتى تمكنت من الوفاء بالتز امات المجموعة الاوروبية في وقت قياسي الامر الذي سرع في قبولها قبل غيرها من الدول التي

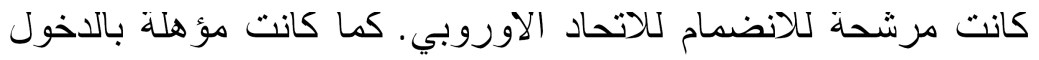

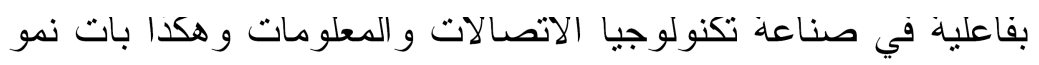

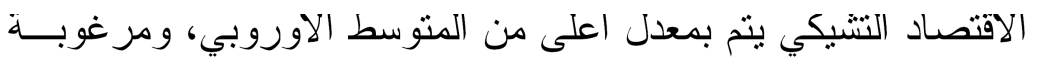
للاستثمار ات والانشطة التجارية. بضاف الى كل ذلك المستوى العلمي

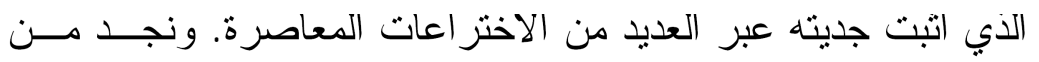
المفيد عرض الملاحظات التوضيحية الاتية: 
- استثر ار ارتفاع الناتج المحلي الاجمالي من 75.3 مليــار دو لار ، عــام 2000حت 161.1 مليار دو لاز عام 2007 توضـح هذه الارقام الاتجـــاه

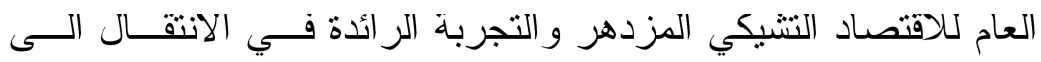

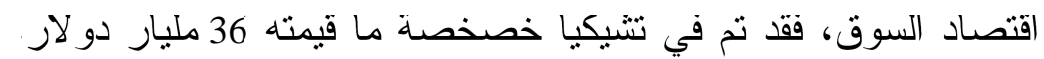

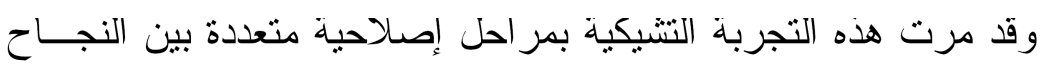
و الإخفاق، ورغم ذلك تحتل جمهورية التشيك المرتبة 21 من 41 بلـــداً

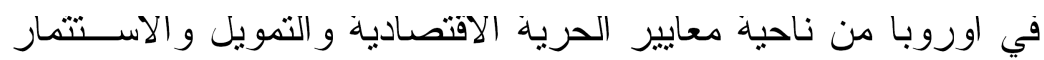

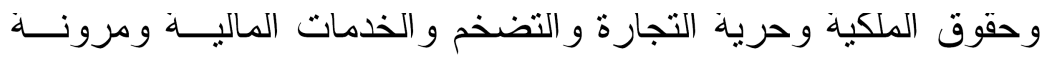

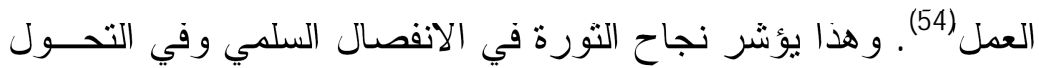
من النظام الاشتر اكي المركزي الى الر اسمالي المؤسساتي الليبر الي. إلا

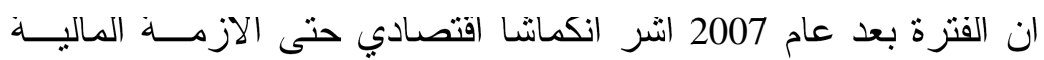
العالمية التي عصفت هي الاخرى لتو اجه التشيك معضــلـة اقتصـــادية جديدة.

\section{نجاح التشيك في الاتحاد الآوربي}

قدم صندوق النقد الدولي شهادة لجمهورية التشيك بانها نجحسـت فـي الني

التحول من الاقتصاد المركزي الموجه الى اقتصـاد سوق يلاعم عضـــوية الاتحاد الاوروبي، فالقطاع الخاص سيطر على 80\% مــنـ المؤسســات

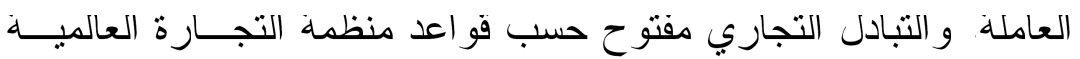
وتطبيق نظام جمركي اكتر تسهيلا مع الدول الثريكة في اتفاقية التجــارة

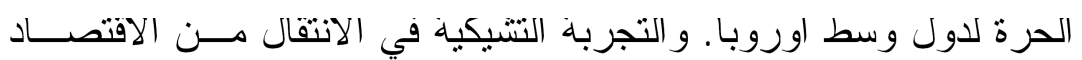

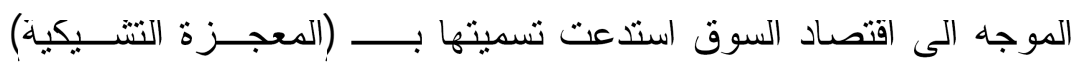
لسر عه الخصخصهة وخفض البطالة و التضخم في الفترة التي تلت التــورة المخملية ما بعد 1989. 


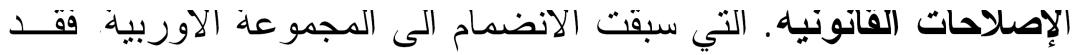
أقدمت الحكومة الى تسريع الإصداحات، بإكمال خصخصة قطاع البنوك

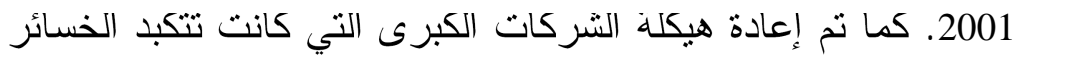
الكبيرة، كما شجعت جمهورية النشيك الاستثمار ات الأجنبية المباشرة بين فئرة

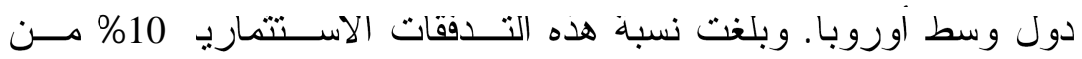

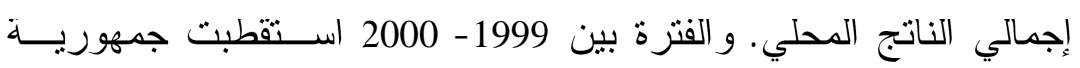

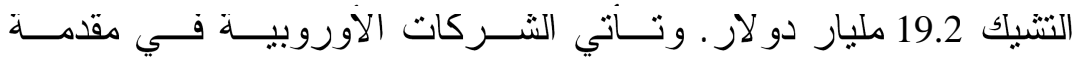
المستتمرين، و احتلت و آلمانيا هولندا المركزين الأولين بتدققات بلغت 5.7

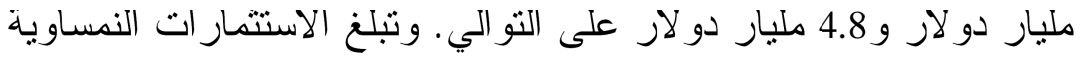

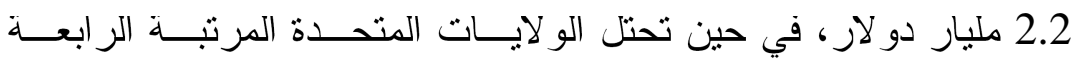

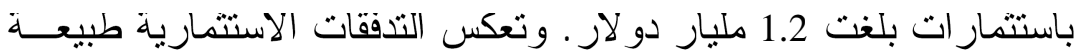

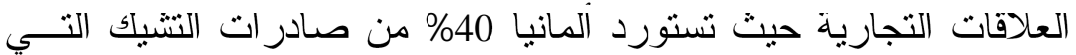
بلغت 40.8 مليار دو لاز في 2002، في حين تمنل الصـــادر ات الالماني ـة 39 من و اردات النشيك التي بلغت 43.2 مليار دو لار في العام نفسه (55) إلا معدل انكماش الاقتصاد التشيكي انتر للفترة 2007-2009 مؤشر ا سلبيا

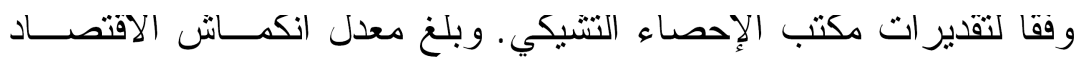

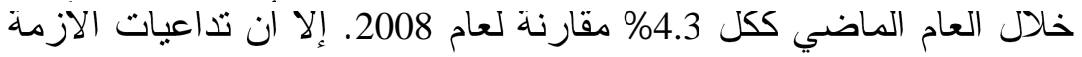

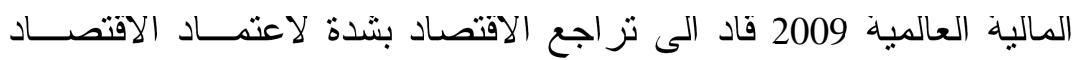

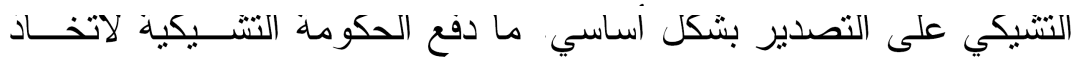

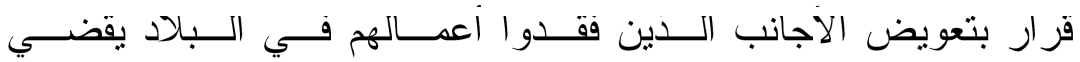
بتقديم خمسمائة يورو وتذكرة سفر بالطائرة لكل أجنبي بهدف ترحيلهم بعد

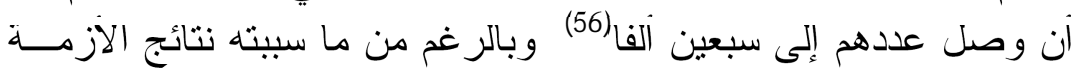

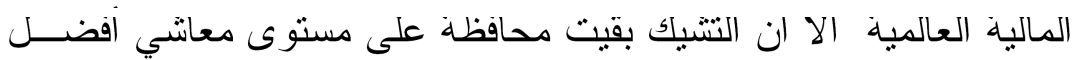

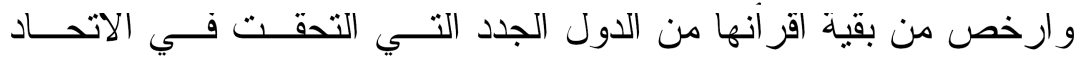
الأوربي. 
نجحت التورة المخملية عام 1989 وبدات مرحلة تاريخية جديــدة فــي

حباة الشعب التشّيكوسلوفاكي، و اخذ القادة الجدد بشر عون بالتحو لات مــن المنهج الاشتر اكي والاخذ بالمنهج اللبير الي. فقد انتشرت وسائل الإعــلام ومنها الصحف المتحررة بعد ان تم إقصاء الشيوعية الى حد كبير، مسـع بقاء إحدى الصحف التي تعبر عن لسان حالهم، و على الرغم من قبــول مشـاركتهم بالانتخابات إلا انهم لم يحصلو ا إلا عـن عــدد محــدود مــن

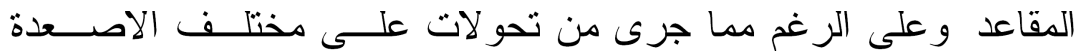
و المجالات، فقد عصفت في البلاد موجة من الغــلاء التتـي لا تثتاســبـ و المستوى المعاشي للفرد و اخد الشيو عيون و البعض من العامة يترحمون على الشيوعية، بعد ان ضعف الامن اتر حل الاجهزة الامنية الشــيو عية، مما ادى الى انتشنار الجريمة، ونتيجة لما اقدمت عليه الحكومـــة الجديــــة على خصخصة القطاع العام حين ثم بالتّربج بيع معظم المر افق العامـــة

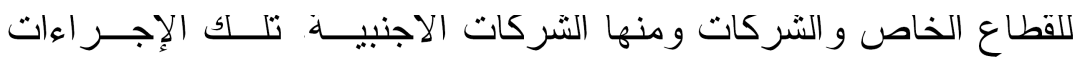
اسهمت بزيادة البطالة، وفي الوقت نفسه اسهم فتح الحدود امسـام حركــة التجارة الحرة و الاستتمار الاجنبي في الاضطر اب الاقتصـادي، و الحقيةــة وكما نرى كان الاهتمام الغربي مركز ا على نجاح التحول من الشــبو عبية الاشتر اكية الى الليبر البية الغربية على الجانب التشيكي، وفــي اعتقادنـــا صرفت جهود كبيرة لنجاح التجربة الانموذج لجمهوربة التشــيك لتكــون البداية التي تتجح بالمنهج الليبرالي ولتتهي الفكر الثيوعي الاشتر اكي من عقلية المجتمع الى الابد في منطقة دول اوروبــا الثــرقية الاشــتر اكية الشيو عيذة

كما شَرع قادة الدولة التشيكية مند وقت مبكر بعد نجاح التــورة 1989 الاخذ في بناء المؤسسات السباسبة وفي مقدماتها وضع دستور جديد للبلاد 
وشكل الدولة الجديدة في اطار من الرؤيا و التصور لما ينبخي ان تكــون

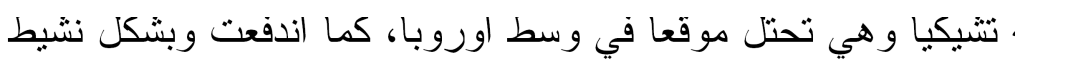

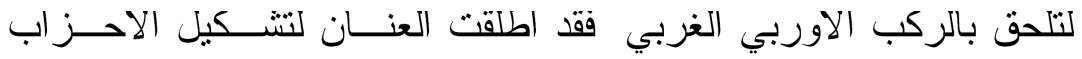

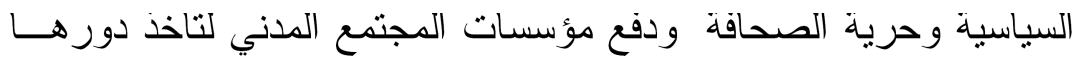

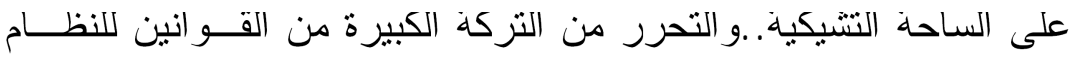

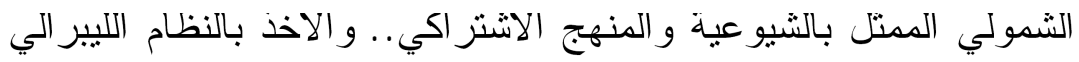

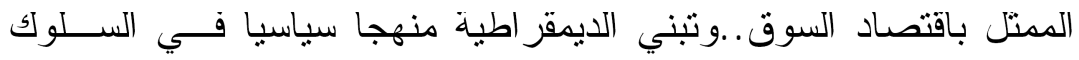

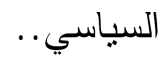

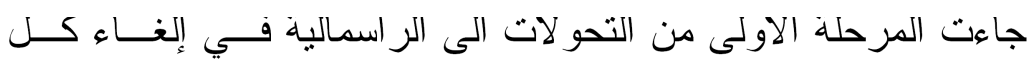

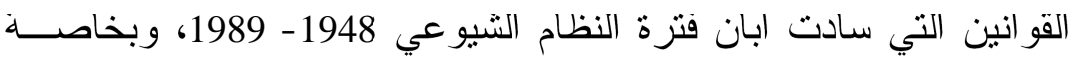
موضوع التاميم، فقد عادت الملكيات الخاصة الى اصحابها ولى وروتتها، من العقار ات و المز ارع الكبيرة و المصانع و غيره ها.

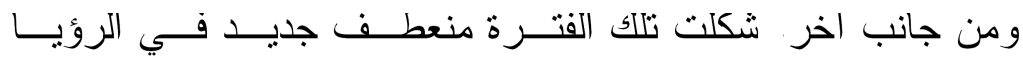
الاجتماعية فقد تبنت البلاد وسمحت بقيام مجمو عة مــن المؤسســـات السياسية، بنشكيل الاحز اب السياسية، كما انطلقت مؤسسات المجتمــع

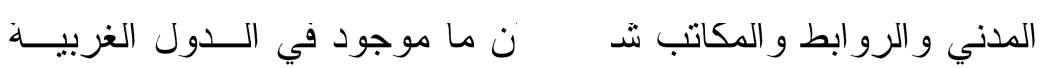
الليبر الية. كما بدات مرحلة جديدة قائمة على الانتخابات الديمقر اطية في مئي

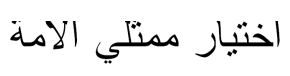

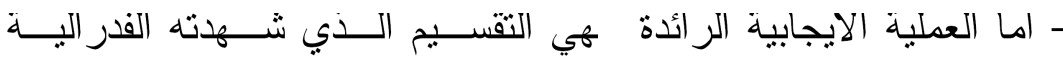

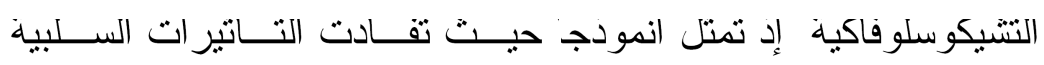

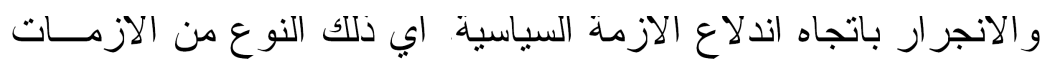

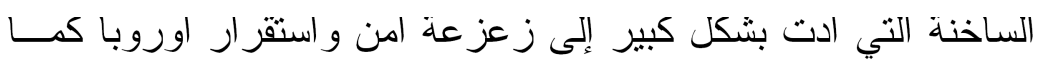
حصل في إعادة النقسيم الجيوسياسي المعروف بــــ (يو غسلافيا السابقة) 
وكما حدث ويحدث من تازم سياسي لبعض الجمهوريــات الســوفيتية السابقة.

فقد جاء التقسيم اتر الاتفاقية التتائية التي تمت بين رئيس حكومـــة

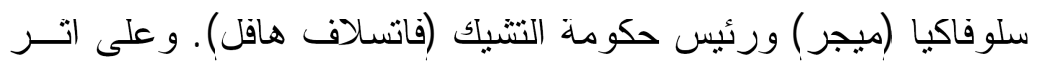

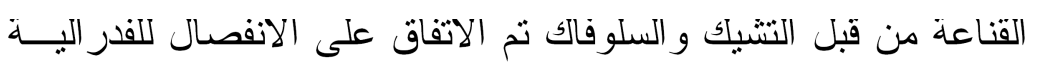

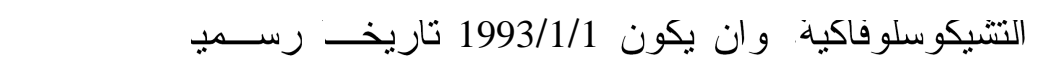

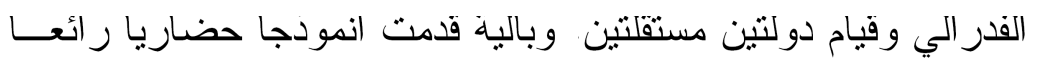

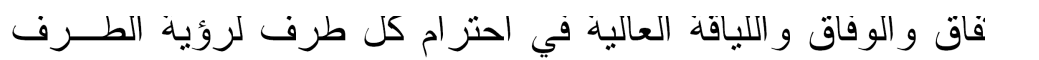

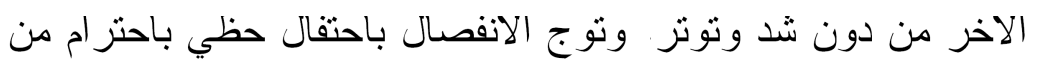

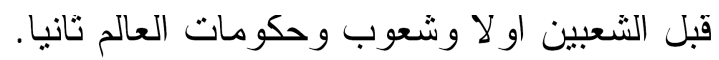

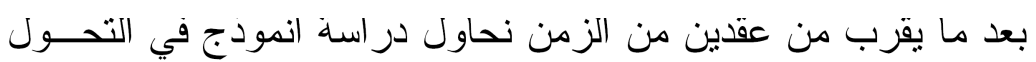

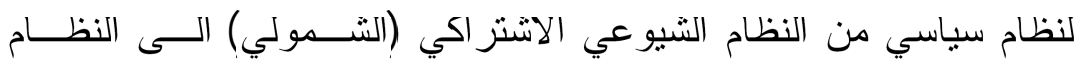
الر اسمالي الليبر الي الديمقر اطي، و لا بد من الإشنارة ان الغـــرب و الإدارة

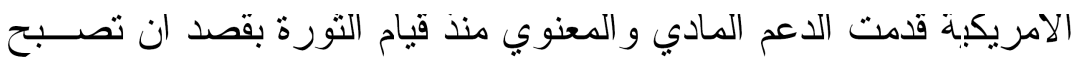

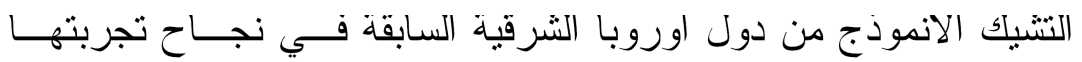
بالتحول الر اسمالي بقصد جذب بقية بلدان اوروبا الثرقية الى تبني المنهج

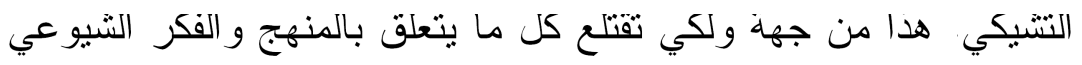

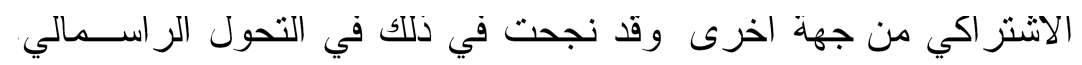

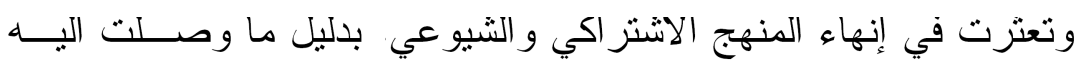

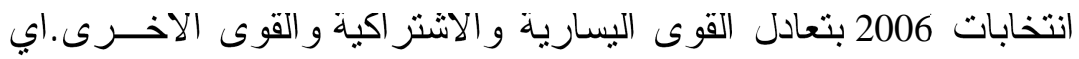
بقيث شريحة و اسعة تحن الى الماضـي بدولة مركزية تسيطر علــى كـلـل المؤسسات في الدولة، وحق المو اطن مضمون من و لادته حتى مماته.

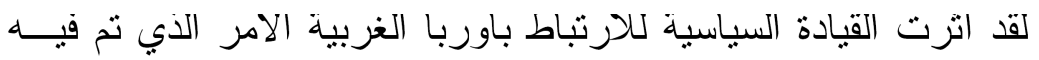
قبول جمهورية التشيك في حلف شمال الاطلسي NATO عام 1999، وبعد 
تحول الدولة إلى اقتصاد السوق مند بداية التسعينات، اجرت استقتاء حول

انضمامها الى الاتحاد الاوربي، حيث صوت 77\% من التشـــك لصـــالح

العضوية، لتصبح جمهورية التشيك عام 2004 احد اكتــر اقتصــاديات

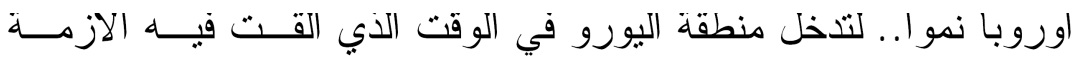

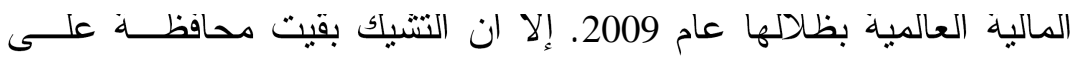

مستوى معاشي افضل وارخص من الدول التي انظمت حـــيتـا للاتحــــاد

\title{
Czechoslovakia As A Model For Peace Disintegration \\ And Transformation From Communist Socialistic Regime To Liberal Capitalistic One: Failure \& Success
}

\author{
Dr. Mahmood Salim Jasim \\ Assist. Prof. International \\ Studies, College of Political \\ Science, University of Mosul
}

After about two decades we try to study a model of transformation for a political system from socialist communism to democratic liberal capitalism in order to clarify the pros and cons affecting each aspect of life by the velvet revolution of 1989 in Czechoslovakia, and the achievements by the democratic transformation, after the political landscape has witnessed the emergence of about 100 parties organizations, movements, and political associations'. moreover, prices have risen $300 \%$ compared with the communist system. A new class emerged, besides the strategic transformations by joining the NATO in 1999, then joining the European Union in 2004. The research also tackles 
the consequences of separation and the political, economic and security movements and failures from 1993-2009.

الهو امش و المصادر

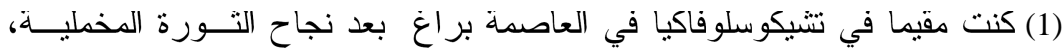

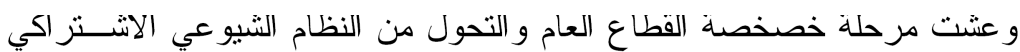

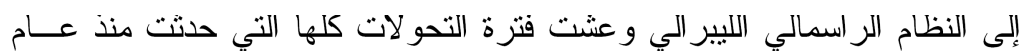

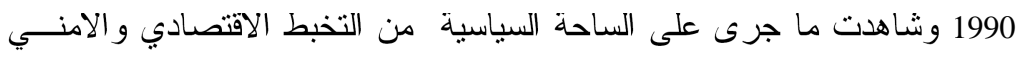

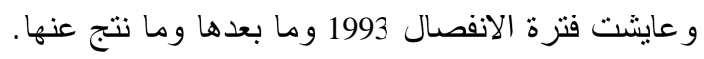

(2) Dějiny Světā 1945 - 1949 Zaredakce Svoboda- Praha 1988 s.221.

$$
\begin{aligned}
& \text { (3) بيير رينوفان، مدخل الى تاريخ العلاقات الدولية، ترجمة فايز كم نقـشَ، بيــروت } 1967
\end{aligned}
$$

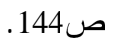

(4) موسى الز عبي، الجيوسباسية و العلاقات الدولية، دمثن، 2004 ص57 -58.

(5) Dr. Eduard Gombar Kobore dejiny Blizkeho Vychodu..ff Uk praha 13/1/1993.

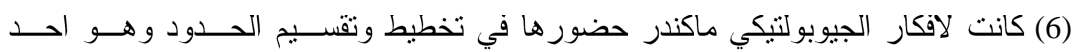

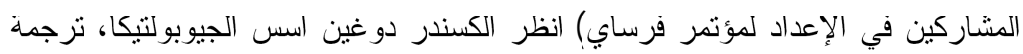

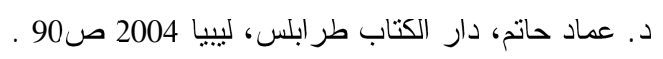

(7) Akedēmia Vied sssp. Hedzināodnē vzthy Po drúhey sveyouej Vojne 19451949 praha 1963/s. 112.

(8) Cs- Národná Rada Česká republika, dejiny Blizkeho Vychodu.ff Uk praha 1993.

$$
\text { (9) بيار ميكال، مصدر سابق } 654 \text { (9) }
$$

Michael Howard, Studies in War and Peace (Temple Smith, 1970) p 251.

$$
\begin{aligned}
& \text { (11) د. محمود سالم السامر ائي، انهيار الاتحاد السوفيتي، مطبعة ابـن الآثــر، الموصــل، } \\
& \text { 2006، ص257. } \\
& \text { (12) انظر سميح عبدالفتاح، انهيار الإمبر اطورية الســوفيتية، دار النتــروق، عمــان 1996، } \\
& \text { ص160. } \\
& \text { (*) المصدر نفسه، سميح عبدالفتاح شغل منصب سفير فلسطين في تنتيكوسلوفاكيا حتى بعـــ } \\
& \text { الانفصال } 1993 .
\end{aligned}
$$




$$
\begin{aligned}
& \text { (13) انظر كتاب، مادلين ولبرايت، السيدة الوزيرة، تعريب د. محمد توفيق البجيرني، شركة }
\end{aligned}
$$

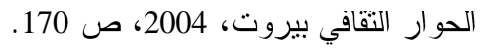

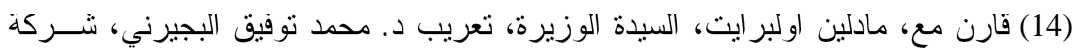

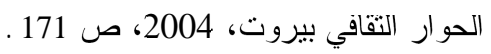

$$
\begin{aligned}
& \text { (15) قارن مع، مادلين اولبرايت، المصدر السابق، ص } 171 \text {-172 } 171 \\
& \text { (16)* على حد تعبير الاستاذ فسليي رئيس معهد دراسات الثنرق اسيات- افريقيا/ كلية الفلسفة }
\end{aligned}
$$

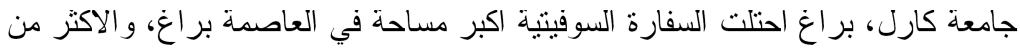

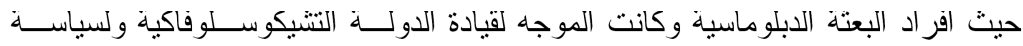

$$
\begin{aligned}
& \text { الحكومة، منذ ربيع بر اغ حتى قيام الثورة المخملية } 1968 \text {-1989. }
\end{aligned}
$$

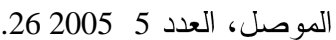

(18) Osama Abbas. Prague... 14/5/2005.

www.azzaman.com/azzaman/articles/2002/1/1 مامة عباس، الثورة المخملية، براغ

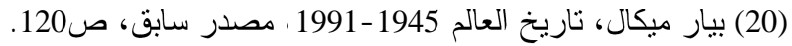

(21) jiné změny režimů in Literární noviny Sametová demokracie (Prague $15 / 11 / 2004$

$$
\text { (22) بر اين بوند، الحرب و المجتمع في اوربا } 1870 \text { - 1970، مصدر سابق ص } 224 .
$$

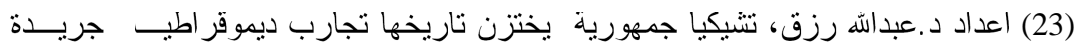

$$
\text { القبس في 2008/02/22. }
$$

(24) Praha .Hospodářské noviny c37.23/2/1993

يفة الاقتصادية، ما زالت تصدر في كل من عاصمة جمهورية التنيك وجمهورية

(26) Praha. Hospodářské noviny. c 37.23/2/1993.

(27) Praha. Hospodářské noviny. c. 28. 10/2/1993.

(28) Praha. Hospodářské noviny. c. 37.23/2/1993.

(29) Praha. Hospodářské noviny. c. 26. 27/1/1993.

(30) Praha Hospodářské noviny. c. 44. 4/3/1993.

(31) Praha Hospodářské noviny.c.40. 26/2/1993.

(32) Praha Hospodářské noviny.c. 40. 26/2/1993. 
(19) 6

(33) Praha Hospodářské noviny. c. 28.10/2/1993 .

(34) Praha Hospodářské noviny.c. 53. 17/3/1993.

(35) Praha Hospodářské noviny.c. 55. 19/3/1993.

(36) Praha Hospodářské noviny. c.37. 23/2/1993.

(37) Czech Republic -Ministry of Industry and Trade/ prepared by Trade Division and Department of Informatics June 1994

(38) سلام عبدالجبار ، الثورة المخملية

http://www.azzaman.com/azzaman/articles/2002/01/01

http://www.azzaman.com/azzaman/articles/2002/01/01 سلام عبدالجبار (39)

(40) Praha Hospodářské noviny.c.38.24/2/1993

$$
\text { (41) سلام عبدالجبار مصدر سابق. }
$$

(42) Atlas Světā / llustroval Brian Delf / Bratislava/ 1992 /s.18

(43) Cs- republika Česká http://www.czso.cz

(44) Národná Rada Česká republika.. http://ar.wikipedia.org

(45) www.cia.gov/publications/factbook/goes/ez.htm

$$
\text { (46) سميح عبدالفتاح، انهيار إمبر اطورية السوفيتية، دار الثروق، عمان 1996، ص154. }
$$

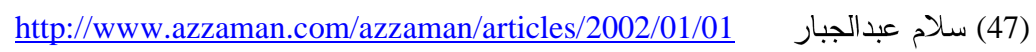

(48) د.محمود سالم السامر ائي، إستر اتيجية الدرع الصـاروخي، بحث، كليــة العلـــوم

السياسية، جامعة الموصل، 4 /2009/4).

http://www.aljazeera.net/portal Templates/postings (49) انظر للمزيد د. خالد الحروبيه، جعه،

http.//www.project-syndicate.org/coatributor/77 الف دارندورف

(51) www.ahram.org.eg/Archive/2001/5/19/WRIT1.HTM

(52) Cs- republika Česká http://www.czso.cz

(53) انظر، اسامة عباس، بر اغ، كبار الساسة التشيك من اصل يهودي، 2007/8 22

http://www.aljazeera.net/news/archive?archiveld=1066567

$$
\text { (54) انظر للمزيد د. خالد الحروب }
$$

http://www.aljazeera.net/portal Templates/postings

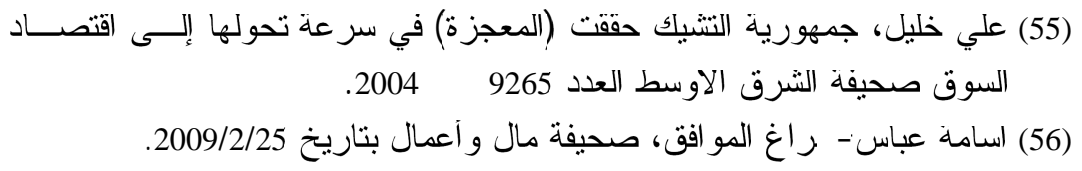


د. محمود سالم السامر ائي [161]

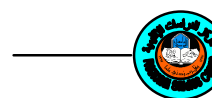

تثيكو سلوفاكيا انموذج للافصال. . - 